\title{
JAK NAPSAT DISERTACI V OBORU ARCHITEKTURA
}

Matúš Dulla

(c) prof. Ing. arch. Matúš Dulla, DrSc.

Odborná recenze: Petr Kratochvíl, Henrieta

Moravčíková,

Tereza Zoulová

Jazyková redakce: Tereza Zoulová

Vydalo České vysoké učení technické v Praze Zpracovala Fakulta architektury ČVUT

2020

Podpořeno vnitřní soutěží FA ČVUT, IP RPMT 2020.

Připomínky k textu poskytli doktorandi/ky Fakulty architektúry a dizajnu STU Bratislava: Kristína Boháčová, Ondrej Dóci, František Dorko, Jakub Hanták, Tomáš Hubinský, Martina Jelínková, Miroslava Kamenská, Katarína Lauková Zajičková, Kornélia

Lincéniová, Mária Novotná, Veronika Vaňová, Romana Hajduková, Kateřina Tesařová a Soňa Otiepková.

První elektronické vydání

ISBN 978-80-01-06790-1

DOI 10.14311/BK.9788001067901

https://doi.org/10.14311/BK.9788001067901

Tato publikace podléhá licenci Creative Commons

\section{OBSAH}

Úvod 2

1. Věda 3

2. Téma 14

3. Metoda 22

4. Co vědí jiní 30

5. Citování 36

6. Etika 44

7. Psaní 48

8. Publikování 66

9. Obhajoba 73

Závěr 77

Literatura 81 


\section{ÚVOD}

Selhaly-li všechny pokusy uvést přistroj do chodu, je načase si přečist návod.

(Murphyho zákony, Cahnův axiom)

Rád čtu návody. Zejména na ty činnosti, které již ovládám. Toto je také návod. Podobných návodů Jak napsat ... je celé moře. ${ }^{1}$ Jen $v$ architektuře jich je nějak málo, byt' se může pochlubit jedním z nejstarších návodů - Vitruviovými Desíti knihami. Když jsem psal tento text, měl jsem před očima však spíše Ecův návod, jak napsat „tesi di laurea“. Snažil jsem se vyhnout návodu, který by byl jen suchým výkladem poslední citační normy nebo jiných povinností. Někde jsem zamíchal do textu i humorné výroky, např́iklad tzv. Murphyho zákony. Ty jsou však často tak výstižné, že je můžete klidně brát vážně. Úvod však má být krátký a slibný. Tak už jenom jedna poznámka: tam, kde píšu autor, disertant, doktorand atd., mám vždy na mysli i autorku, disertantku, doktorandku atd.

Praha, jaro 2020; Bratislava, léto 2020 


\section{VĚDA}

Astronom, matematik a fyzik spolu trávili dovolenou ve Skotsku. Z okna vlaku pozorovali černou ovci uprostred pole. "Pozoruhodné, " řekl astronom, "skotské ovce jsou černé!" Fyzik namítl: "To ne, jen některé skotské ovce jsou černé!“ Matematik si povzdechl a řiká: „Ve Skotsku existuje alespoň jedno pole, na kterém se nachází alespoň jedna ovce, která je alespoň z jedné strany černá."

„To není žádná věda!“ - určitě jste už slyšeli takový výrok. Všichni víme, že to znamená: „Není to složité, není to tak těžko srozumitelné, jak tomu bývá ve vědě. "Vědou se zde tedy rozumí něco složitého, komplikovaného, laikovi těžko pochopitelného. Vưči vědě to není míněno nikterak negativně, právě naopak. Její složitost a intelektuální náročnost se většinou chápe jako vyznamenání, pozitivum, jako ten správný rys. $V$ moderní společnosti se věda stává dokonce čímsi jako náboženstvím.

\subsection{VĚDA JE...}

Když politici v Československu váhali, zda dokončit velké vodní stavby na Dunaji, mnozí požadovali, aby o tom rozhodli odborníci a vědci. Jenže kteří? Ekonomové, kteří budou hodnotit zisky a ztráty? Ekologové a ochránci př́rody, kteří budou hájit zájmy fauny a flóry? Dopravci, kteří požadují odstranění brodů? Energetici, kteří uvítají špičkové dodávky elektřiny? Každý z nich dokázal analyzovat do hloubky svou problematiku, pro laika př́liš složitou, ale prostá a laikovi pochopitelná otázka - zda to dostavět - zůstala na bedrech politiků.

I při korona epidemii (která probíhá právě, když píšu tyto řádky) vidíme, jak se rozhodování politiků, někde více, jinde méně, opírá o poznatky, jenž poskytuje věda, a stejně jako věda váhá tam, kde poznáním ještě nedisponuje. Různé skupiny vědců nabízejí odlišné názory, které se sice opírají o př́sně vědecké poznání, ale také do nich prosakuje jejich subjektivní názor.

Věda stojí na informacích, které nezmizí výměnou vlády, a věda neříká, co je třeba v daném politickém uspořádání dělat. Věda také má metodické nástroje, jak se vypořádat se subjektivitou či osobním zaujetím. Její neutralita spočivá právě ve schopnosti vybrat z klubka problémů jeden segment a ten důkladně prozkoumat. ${ }^{3}$

Fyzik Richard Feynman napsal, že „vědecké poznatky jsou souborem tvrzeni prozkoumaných s různým stupněm jistoty - některá tvrzení jsou naprosto nejistá, některá skoro jistá, ale žádná nejsou jistá absolutně. My vědci jsme na to zvyklí a považujeme za naprosto normální, že si jisti nejsme a že je možné žít a nevědet. Avšak nevím, zda si každý uvědomuje, že je to pravda. " 4

Přitom i uvnitř vědy jako celku jsou protikladné tendence. Dokonce i v jednotlivých vědních oborech. Spory vědeckých škol dovedli Maxe Plancka k vyjádření, že „nová vědecká pravda nevítězí tím, že by své odpůrce přesvědčila a pochopili by ji, ale tím, že zemřou a že ji prijime za svou nová generace, která teprve vyroste. “5 Vůči Einsteinově zdánlivě fantastické teorii relativity se zvedl v jejích počátcích velký odpor a také jeden z nositelů Nobelovy ceny ze Slovenska, fyzik Philipp Lenard, se proti ní postavil. Dokonce si vypomohl rasovými argumenty, když psal proti ní své dávno zapomenuté dílo Německá fyzika.

Věda není jen ideální a složitá moudrost, jsou to i omyly, které při poznávání vznikají. Vědec par excelence Aristoteles si myslel, že žena má méně zubů než muž, Galileo určil na základě analýzy Danteho díla polohu a tvar pekla i to, jak velký je d'ábel. O éteru se ve fyzice mluvilo ještě donedávna a víra $v$ to, jak otočit postel v ložnici na základě toho, kde v místnosti poprvé přespí pes, se těší i dnes velké důvěře. Tyto řádky píšu, jak je jistě vidět, s posměchem, ale pro vědu je typické, že je otevřená diskusi a ani podobně pochybné podněty neodbude mávnutím rukou a je-li to jen trochu možné, je ochotna podrobit je zkoumání. Součástí vědy jsou tedy i pochybnosti, ba dokonce chyby, které vědci dělají. Přehnaně by se dalo rríci, že hlavním úkolem vědy dnes je odstraňovat chyby, které udělala včera. 


\section{Co patři do vědy}

Nejobecnější definice vědy zahrnuje leccos. Například samotné vědce, vědkyně i instituce, ve kterých působí. Již z antických počátků vědy víme o jejích výjimečných osobnostech, ale víme také o institucích: okolo Platóna byla Akademie, Pythagoras měl svou záhadnou školu. Anebo jiný príklad z výzkumu architektury: za francouzským klasicismem byla v pozadí instituce - slavná pařížská polytechnika a na ní profesor Jean-Nicolas-Louis Durand (1760-1834), autor učebnice, která se stala základem téměř celého školství v 19. století. Ta je už zapomenuta, ale její základní teze - pravá krása se rodí z dobré dispozice - přetrvala.

Složitá struktura dnešních vědeckých institucí a zejména otázky jejich rozumného financování předpokládají určitý stupeň vzájemné dělby práce a kooperace, což je fenomén, který je také součástí široce chápaného pojmu věda.

Kontinuálně fungující věda nemůže existovat bez vědeckých pojmů. Nové poznatky často vyžadují nové pojmy. Nejzáhadnější jsou ty, kde se vědecké poznání zcela vzdaluje od každodenní zkušenosti, např́klad při výzkumu mikrosvěta. Architektuře se taková složitost vyhýbá, ale i zde probíhají posuny obsahu zkoumaných pojmů, staré pojmy se nově definují a vynořují se nové pojmy a kategorie. Například pojem „veřejný prostor“ je sice významově průzračný, ale jeho detailnější význam je dnes jiný, než byl např́klad v teorii funkcionalismu. Vědecké termíny, jejich obsah, definování, slovníky, které je vysvětlují, diskuse o nich a posuny jejich významů, zavádění nových pojmů, to vše je rovněž součástí vědy.

Thomas S. Kuhn ve svém díle Struktura vědeckých revolucí mluví o tom, jak se začínající vědci učí určitým zavedeným experimentům, jak rozvíjejí experimenty nové, ale staví na zkušenosti s původními východisky, které Kuhn nazývá paradigmaty. Dosavadní zkušenost, historie zkoumání potvrzená minulými autoritami, zjednodušeně řečeno zvyk - to je rovněž součástí vědy jako takové. Ačkoli přitom platí, že součástí vědy je i pochybování o stereotypech, o minulých pravdách, hledání jejich chyb a diskuse o nich.

To, jak dělá vědec experiment, patří do další oblasti, která je také součástí vědy - jsou to metody, metodiky, procedury a techniky, kterými se výzkum uskutečňuje.

Vědu dále tvoří stávající poznatky, uložené v publikacích, zprávách, archivech, encyklopediích a databázích nebo přítomné ve vědomí vědců či vyučované na univerzitách.

No, a nakonec zmíním ještě jednu oblast, která tvoří nedílnou součást vědy, a tou je sféra, kde se ve vědě komunikuje, tedy publikování výsledků a referování a diskuse o nich, jejich posuzování a citace.

\section{Vlastnosti vědy}

Nejvšeobecnějšími vlastnostmi vědy jsou:

- skepse a zvědavost - v tom nejlepším, vůbec ne negativním slova smyslu, tj. neustálé pochybování o tom, zda je současné poznání správné, jinak řečeno je to „bádavé pochybováni“;

- jednoznačnost - věda vychází z co nejpřesnějších definic, její výsledky se zaznamenávají písemně. Upřednostňuje se tzv. Ockhamova břitva, což je princip připisovaný teologovi a filozofovi Williamovi Ockhamovi (asi 1287-1347), že pokud máme pro nějaký jev několik vysvětlení, nejčastěji (ale ne vždy) je správné to, které je nejméně komplikované;

- transparentnost - co možná nejúplnější popis toho, jak se přišlo k výsledkům výzkumu; odkazuje se na jiné vědecké práce, ze kterých se vycházelo;

- ověritelnost souvisí s transparentností - vědecké výsledky, fakta a informace se mohou kdykoli zkontrolovat, verifikovat nebo falzifikovat, chyby jsou předmětem kontroly a oprav, mylné práce se stáhnou z publikování;

- objektivnost - výsledky vědeckého výzkumu nemají subjektivní zabarvení, uvádějí se pouze objektivní závěry;

- zevšeobecňování - poznání vědy, ačkoli je založeno pouze na několika př́padech, se vztahuje ke všem ostatním případům téhož druhu;

- spolehlivost - fakta a vztahy, které výzkum popisuje, zůstávají dostatečně dlouhou dobu pravdivé; 
- otevřenost a poctivost - vědecká práce vysvětluje věci neutrálním způsobem a bez autorské předpojatosti, při publikování se využívá diskuse, ve které sám autor upozorní na případné limity nových poznatků.

\section{Definice vědy}

Definic vědy je mnoho a někteří autoři už pro šírku pojmu dokonce pochybují o tom, zda má smysl vědu nějak definovat. Za vědu se považuje taková disciplína, která má jasně vymezený předmět čili oblast zkoumání (to je v oboru architektura asi jediné víceméně splněné kritérium) a vlastní metodu zkoumání. $K$ tomu se ještě někdy přidává požadavek na vlastní terminologii s přesně vymezenými pojmy, případně vlastní univerzitní studijní obor.

Ve vtipné knížce o filozofických pověrách charakterizoval polsko-německý filozof a logik

J. M. Bochenski vědu jako soubor tvrzení s následujícími vlastnostmi:

- týká se výlučně faktů, které se odehrávají ve světě;

- mají objektivní charakter, jsou intersubjektivně ověřitelné, tj. ověřitelné prostřednictvím přinejmenším dvou osob;

- byly zjištěny a jsou uspořádány s péčí typickou pro vědce;

- byly publikovány specialisty $v$ dané oblasti. ${ }^{6}$

Na rozdíl od běžného poznávání je to vědecké založené na racionálním neboli rozumem přisně kontrolovaném postupu, který je metodicky promyšlen. Nové poznatky se vytváří na základě uvažování, které odlišuje specifické vlastnosti věcí a jevů a současně zjištuje jejich obecné a podstatné vlastnosti a vztahy.

Darwinův bojovný obhájce Alfred Russel Wallace však poukázal na podobnost běžného a vědeckého přístupu: „Věda není nic jiného než cvičený a uspořádaný zdravý rozum. Věda se od něj liši jen tak, jak se může lišit ostřilený voják od čerstvého nováčka, a její metody od způsobů zdravého rozumu jen tak, jak se souboj gardistů liši od způsobu, jak divoch drží kyj. "

Univerzální definice vědy jsou však často dost mlhavé. Musí zahrnout nejen současnou složitost a množství variant, ale i minulé vědy či pavědy. Takže někteří autoři na otázku, co je věda, odpovídají: „Věda je to, co za vědu považuji vědci v daném oboru. ${ }^{\prime 8} \mathrm{Z}$ hlediska naší nejisté disciplíny architektonické vědy - je to sympatická definice.

\section{Dějiny vědy, zápas teoretiků s empiriky}

Ponor do hluboké historie vědy, o který se zde pokusím, se možná bude zdát ve chvíli, kdy disertant stojí před navýsost aktuálním problémem, nemístný, ale pomůže snad najít argumenty pro volbu metody zkoumání. Věda $v$ dobách dávných nezačínala tak, jak pracuje dnes dominantní věda o přírodě, resp. vědy technické. Jónská věda, která stojí na počátku evropské vědecké tradice, se oddělila od mytologie tak, že vytvářela představu o světě a kosmu na základě zkušenosti. Současně se však ptala na př́činy. Jasně už rozlišovala mezi ideální strukturou světa a nepravidelnostmi reality. Vědecké poznatky Řeků platily však jen pro svět hvězd. Novověk se odvrátil od vysvětlování dokonalého světa a dal se na smyslové a experimentální vysvětlení. Podle Galileiho je kniha př́rody psaná jazykem matematiky a prosazoval myšlenku „Co je měřitelné měřit, a co se ještě měřit nedá, udělat měřitelným. " Empiricky a experimentálně byl orientován i Francis Bacon, který stál na počátku britské empiricko-induktivní vědy. Nespoléhal se na typicky scholastické odpovědi, které odkazovaly na autority (tj. na bibli, Aristotela nebo na církevní otce), ale se obrátil k bezprostřední zkušenosti, k pozorování prírody a k experimentování. ${ }^{9}$

Jinou cestou se vydal René Descartes (1596-1650). Vypracoval metodu deduktivního přístupu, při které nebylo potřeba vyjít z badatelského kabinetu. (Pravda obrazně, sám Descartes se potuloval po celé Evropě, jako žoldák se zúčastnil i bitvy na Bílé hoře - na straně vítězů, později zase bojoval $\checkmark$ protestantském vojsku.) Vytyčil zásady nezávislého logického myšlení a postupu zkoumání. Podle něj „je třeba hledat ne to, co jiní mysleli nebo co sami tušíme, ale to, o čem můžeme mít jasnou představu a zřejmou intuici nebo co můžeme s určitostí dedukovat. (...) Celá metoda spočívá v (...) uspořádání těch věcí, na které se má rozum zaměřit, abychom našli nějakou pravdu". ${ }^{10}$ Jeho slavný výrok Cogito ergo sum má vyjádřit výsledek očištování myšlení od nepravd až na to, co je nepochybně 
jisté: Myslím, tedy jsem. Neptá se už na povahu jsoucna nebo na metafyzické souvislosti. Poznávat se podle něj dá i vycházením od jedné věci $k$ druhé.Descartův přímočarý racionalismus, kterým se chtěl odpoutat od svazujícího replikování scholastických moudrostí, sálá i z přirovnání, ve kterém použil odkaz na architekturu: „,... v dílech složených z více částí a konaných rukama různých mistrů je často méně dokonalosti než $v$ dilech, na kterých pracoval jen jeden. Napřiklad stavby, které podnikl a dokončil jediný stavitel, jsou obvykle hezčí a lépe uspořádané než stavby, které se pokoušelo sestavit několik stavitelů s použitím starého zdiva, postaveného k jinému účelu. A stará města ... jsou obyčejně špatně rozvržena - při srovnání s dobře uspořádanými městy, která inženýr vyměřil na volném prostranství podle svého záměru. "11

Descartova věda je založena na úsudku, Baconova na indukci. Angličan tvrdil, že „,bez zkušenosti nelze nic vědět" a domníval se, že Descartovy postupy jsou pochybné a mohou vést nikoliv k popření minulých omylů, ale $k$ jejich utvrzení. Oba však stáli na počátku ucelené metodologie moderní vědy, která vytvořila základy mohutného přírodovědného vědeckého poznání. Metody matematiky a fyziky, kličcových piliřů vědy, se staly měřítkem toho, co je vědecké.

Vědu dlouho provázelo dilema, kterým bylo náboženství. Galileo doplatil na své samostatné úvahy, které ho vzdalovaly od biblického výkladu, Koperník se kritice vyhnul, protože publikoval své převratné dílo zcela na sklonku života. Descartes věděl o Galileiho problémech a svou rozpravu o metodě vydal nejprve anonymně, protože se obával reakce církve. I v rozhovoru s Komenským komentoval jeho náboženský zápal taktně diplomaticky.

Otec sociologie Auguste Comte (1789-1857) formuloval později na základě racionalistické vědecké linie pozitivistickou představu o tom, že věda má stát výlučně na pozitivních jasných faktech a nemá se pokoušet o žádné metafyzické konstrukce. Pozitivismus a jeho mladší bratr novopozitivismus se úspěšně pěstovaly i v první polovině 20. století. Matematizace měla být zkušebním kamenem pravé vědeckosti.

\section{Proti pozitivismu}

Německý filosof Wilhelm Dilthey (1833-1911) vycházel z přesvědčení, že mezi přírodními a sociálními vědami je podstatný rozdíl a rozdělil vědu na dvě skupiny. Vedle zmíněných „vysvětlujících“ věd, které dokáží vytvořit předpověd", jak se daný jev bude chovat za stejných podmínek (matematika, fyzika), vytvořil skupinu věd duchovních, které usilují svět chápat a vysvětlovat, ne hledat jeho zákony a zákonitosti (např. sociální vědy, historiografie, uměnověda). Jsou z principu obrácené do minulosti, historické ${ }^{12}$ a jejich hlavní metodou má být hermeneutika - čili výklad textů. ${ }^{13}$ Wilhelm Windelband (1848-1915) rozlišoval z podobných důvodů vědy nomotetické, tedy takové, které popisují svůj předmět obecnými zákony (to jsou hlavně vědy prírodní), a idiografické, kam patří vědy o kultuře (podle Diltheyho duchovní), které se zabývají popisem, "chápáním“ světa, zatímco formulování jednoznačných zákonů a zákonitostí je mimo jejich záběr. Ty první jsou vědami o událostech a mluví o tom „co jednou bylo“, ty druhé jsou o zákonech a učí, „co je vždy". ${ }^{14}$

Dlouho přetrvávala zbožná úcta $\mathrm{k}$ dokonalosti poznání nomotetických věd. $\mathrm{K}$ jejímu zpochybnění přispěl rakousko-americký filozof Karl Raimund Popper (1902-1994), který upozornil na nejistotu indukce. Kdybyste denně ráno potkávali jednoho a téhož člověka, měli byste dojem, že se to bude opakovat i v budoucnu, není to však vůbec nezbytné. Nebo jiný Popperův př́klad: z faktu, že jsme zvyklí na to, že vídáme jen bílé labutě, nevyplývá, že se tu a tam nemůže vyskytnout i labut' černá. Podle Poppera i vědecké poznání založené na takové indukci je nejisté. „Věda nespočivá na skále, ale spiše představuje budovu, kterou vystavěli nad močálem na kůlech, které jsou zapuštěny shora dolü, aniž dosáhli prírozené nebo pevné podloží. Pokud však nezapustí pilǐre hlouběji, neznamená to, že nedosáhli základ. Jsme spokojeni, pokud jsou piliře dostatečně pevné, aby stavbu unesly-alespoň částečně. " ${ }^{\text {} 5}$

Popper z toho vyvodil, že ne verifikace vědeckých teorií je úkolem vědy, ale naopak, že na teoriích se hledají jejich nedostatky a nahrazují se teoriemi novými. Tento postup nazval falzifikací. Skepticky se stavěl k vědám, jejichž konstatování nelze falzifikovat. Taková je podle něj Freudova psychoanalýza nebo Marxovo učení. 
V Murphyho zákonech je tento fakt vtipně zachycen v tzv. Hawkinsonově teorii pokroku: Pokrok nespočívá v nahrazování nesprávné teorie správnou, ale v nahrazování méně nesprávnou.

Zmíněný Thomas Kuhn proti Popperově představě postavil vývoj vědy jako střídání normální vědy a vědecké revoluce. ${ }^{16}$ Podle něj normální vědec pracuje $v$ duchu dobového paradigmatu, $t \mathrm{t}$. konformně působí v soustavě obecně prijímaných názorů, co a jak se má zkoumat, experimentovat a vyučovat. Nezabývá se nějakou falzifikací, právě naopak, poznání potvrzuje verifikací. Postupně se však vynořují pochybnosti. Kuhn uvádí exemplární příklad: Einsteinovy výhrady vůči všeobecně panujícímu Newtonovu výkladu fyzikálního světa. Pochybnosti rostou, až vedou k revoluční změně, k vytvoření nového paradigmatu: Einsteinově relativistické fyzice.

\section{Věda jako umění?}

Můžete se zde znovu zeptat, jaký význam má pro chudáka doktoranda tento diskurs evropských a amerických filozofů vědy. No, uleví se vám, když přejdeme k dalšímu účastníkovi této diskuse. Paul Feyerabend (1924-1994) postřehl, že věda je tak členitá, že se na mikroúrovni neřídí velkými teoriemi zmíněného typu, že v ní bují kdejaké metody, a právě toto bujení (proliferace) přispívá $\mathrm{k}$ její plodnosti. Dospěl k tomu, co nazval metodologickým anarchismem a postmoderně konstatoval že "všechno je dovoleno". V názvu svého klíčového díla Rozprava proti metodě ${ }^{17} \mathrm{z}$ roku 1975 parafrázuje Descarta a upozorňuje na to, že nejvýznamnější objevy vznikly právě díky porušení pravidel uvažování, tedy tehdy, když se vědec dokázal vymanit ze vžitých konvencí. Ještě více by vás mohla zajímat jeho kniha Věda jako uměni, ${ }^{18}$ kde hovoří o podobnosti vědeckého a uměleckého poznávání světa. Zůstává pravda pouze na poli klasického antického a renesančního umění a na nejisté moderní pole se nepouští. Podobně jako Alois Riegl, který nestavěl umělecké styly různých období hierarchicky, ale chápal je jako rovnocenné, i Feyerabend vidí ve vědě různé „styly", které jsou otázkou volby. Podle něj se člověk i při rozhodování o vědě nebo proti ní rozhoduje tak, jako o tom, zda je pro nebo proti punk-rocku.

Diskuse polemiky mezi přísnou prírodovědnou linií a linií společenskovědnou pokračuje dodnes. Mohutné úspěchy vědy, která dokáže formulovat zákony a na základě toho předvídat budoucnost, jsou silnými argumenty proti vědám, které zkoumají složitější celky, jejichž součástí jsou i autonomně se rozhodující lidé, a které neformulují zákonitosti, ale jen svět popisují a usilují o jeho pochopení. Týká se to i našeho oboru, kde se na jeho předmětu - architektuře - zkoumají záhady jak prírodovědně-technické, tak kulturní a společenské.

\subsection{VĚDA, PAVĚDA A KOUZLO NESMYSLU゚}

Ne všechny druhy poznávání se považují za vědecké. Vědecká komunita stojí bedlivě na stráži a zvažuje, komu a čemu dovolí vstoupit do vědeckého království. Dodnes trvá diskuse o hranici, co je vědecké, dodnes jsou tací, kteří kompetentně obhajují novopozitivistickou koncepci prísně „nomoteticky“ limitované vědy: co nedokáže formulovat zákon, není věda, co se nedá falzifikovat, do vědy nepatří. Jsou však také další oblasti „poznáváni“", které stojí jednoznačně mimo vědu, i když se za ni někdy vydávají. Nazýváme je pavěda nebo pseudověda.

\section{Od omylu k pavědě}

Pod názvem pavěda rozumíme takové soubory znalostí, které se vydávají za vědecké, ale vznikají mimo základní pravidla vědy. Mezistupněm k pavědě je nepoctivá nebo přímo podvodná vědecká práce. Typickou pavědou byla frenologie, která tvrdila, že dokáže z tvaru lebky vyvodit duševní vlastnosti člověka. Dodnes se neví, zda za tzv. Piltdownským člověkem byl pokus o nevinný vtip, který se vymkl neznámému autorovi z rukou, anebo to byl vědomý podvod, který měl dokázat, že i Britové měli svého dávného předka.

Někdy je však vědecký omyl prostě součástí postupného vědeckého poznávání. Například dlouho přetrvávalo přesvědčení, že aténský Parthenón byl bezbarvý. Postupným výzkumem bylo zjištěno, že tato Winckelmannova představa byla mylná a že antické objekty pưvodně hýřili pestrými 
barvami. Část pseudovědy, například parapsychologie nebo psychotronika, jsou založeny na dědictví mystiky nebo okultismu.

Některé z pseudověd se však stále těší velké podpoře a reputaci. Stačí zmínit homeopatii nebo podobné léčitelské postupy založené na naivní laické víre nebo přetrvávající dezinformace o vztahu očkování a autismu, přestože je známo, že se zakládají na vědeckém podvodu. V čínském systému „feng šuej" se za ucelené a fundované vydávají také triviální a jalová obecná konstatování. ${ }^{19}$

Mezi vědou a pavědou jsou však oblasti, kde je přísně vědecký přistup opatrný v odsuzování a nabízí ověření standardním vědeckým způsobem. Mezi časté argumenty pavěd však patří odmítnutí vědecké kontroly, například proto, že se běžné vědecké metody považují za přiliš hrubé na zachycení různých subtilních „energii“" a „duchovních sil“, které pavěda vyznává. Pseudovědy mají tendenci používat vágní, přehnaná nebo neověřená tvrzení, spoléhají se na potvrzování, nezaznamenávají vývoj v poznávání svého předmětu a odmítají kritické zkoumání jinými. ${ }^{20}$

Některé pseudovědecké názory jsou založeny pouze na naivním výkladu světa, který podezř́ivá oficiální, státem podporovanou vědu ze zaujatosti a ze spiklenectví. Svou uzavřenou argumentační soustavu si např́iklad vytvořili zastánci ploché Země nebo ti, kteří pochybují o přistání člověka na Měsíci. Na fiktivní záhady, jinak lidsky velmi přitažlivé a sledované, je orientovaná tzv. ufologie.

Sklon podezírat nějaké instituce nebo skupiny ze spiknutí dovedl ad absurdum Achim Held, který vymyslel Bielefeldské spiknutí. Je to parodie na konspirační teorie, která tvrdí, že německé město Bielefeld neexistuje. Jeho existence je jen fáma a Ize ji odhalit třemi otázkami: 1/ Znáte někoho z Bielefeldu? 2/ Byli jste někdy v Bielefeldu? 3/ Znáte někoho, kdo byl v Bielefeldu? Většina odpovědí je záporná - ty jsou od obětí tohoto spiknutí. Kdo odpoví na některou otázku kladně, je spiklenec.

\section{Vědecké $a$ antivědeckými postoje}

Mezi jasně vědeckým a antivědeckým postojem a přístupem mohou být jasné rozdíly, ale někdy také plynulý přechod. Na straně vědecké stojí obvykle objektivita, extrapersonalita a skepticizmus vůči autoritě, zatímco na opačné straně je častá subjektivita, personalismus a autoritativnost. Vědeckému postoji je bližší světonázor sekulární, progresivní a evoluční, naproti tomu antivědeckému je blízký světonázor sakrální, konzervativní a ten, který upředňostňuje náhlé skoky a změny. Při metodách poznávání se za vědečtejší pokládá přístup kvalitativní, racionální a založený na důkazu, zatímco při antivédeckém přístupu je častější kvalitativní nazírání, důraz na jedinečnost a moralizování. ${ }^{21} Z$ uvedeného je však zřejmé, že hranice mezi vědou a antivědou anebo přímo pavědou je někdy mlhavá, věda si však vytváří a reviduje mechanismy na to, aby její poznání odpovídalo skutečnosti a zachycovalo ji.

Problematika, která je blízká architektuře, není nutně vždy na té straně, která je typicky přísně vědecká. Např́klad př́iklon ke konzervatismu je přirozeným postojem ochránců architektonických památek, v uměleckých manifestech jejich autoři nejednou moralizují, při sakrální architektuře se rádo mluví o nadsmyslovosti, genius loci je jednou pověra (ve funkcionalismu) a jindy akceptovaná realita (u Norberg-Schluza a v postmoderně). Přesto je rozdělení polárních pozic vcelku poučné pro diferenciaci extrémně vědeckého a spíše nevědeckého či antivědeckého postoje.

\section{Skepse proti/ve vědě}

Proti vědě se však trvale udržuje skepse, ${ }^{22}$ která pramení z toho, že:

- vědecké poznání je trvale neúplné, falzifikace ve vědě dokazuje chyby předchozího poznání, a tedy vlastně chyby vědy jako takové;

- ve vědě se prý uvolnily síly, které nás ohrožují a způsobují ekologickou a mravní krizi a vědecké poznatky se dají nejen využít, ale i zneužít;

- mnoho vědních disciplín již používá jazyk, kterému laik nerozumí;

- stále hrozí strach z nepoznaného, nejistota z budoucnosti, obava z narušení „přirozenosti“ člověka.

$Z$ těchto výhrad se pak odvozuje, že jsou údajně i jiné, mimovědecké formy poznání a bojuje se proti scientizmu, který si prý uzurpuje nárok na monopolní postavení při poznávání světa, ačkoli poskytuje pouze omezené výsledky. 
Vědecké společenství, kromě toho, že nabízí své vědecké rezultáty proti těmto pseudovědeckým nebo antivědeckým silám, zakládá např. skeptické společnosti. A bojuje i humorem. Například raritním a komickým vědeckým výzkumům udělují lg Nobelovy ceny a proti náboženským předsudkům vytvořili svého „boha“: létající špagetové monstrum. Jedno z jeho osmi přikázání (dvě z původních deseti se rozbila při sestupu z hory) se dotýká i našeho oboru: monstrum nechce, aby se pro Jeho Nudlovitost stavěly kostely za miliony. Ty peníze je potřeba raději využít na boj proti chudobě, léčení nemocí, šíření lásky nebo na poplatek za kabelovku.

\subsection{DĚLENÍ VĚD}

Věda se chápe v různé šírce, souvislosti i jazykovém kontextu. Anglické „Science“ je věda $v$ užším slova smyslu, především ta induktivně-empirická, která používá kvantitativní metody, tj. umí změřit zkoumané veličiny. Patří sem prírodní a technické vědní obory, samozřejmě v čele s matematikou. Je protikladem skupiny věd označovaných jako „Arts“, které nevládnou takovými přesvědčivými výzkumnými nástroji. Německé „Wissenschaft“ vymezuje vědu širší, zahrnuje např. i sociologii, psychologii nebo dějiny umění a akceptuje se zde i normativní př́stup. Latinské „scientia“ je nejtolerantnější označení věd, do kterého spadá moudrost a vědení obecně.

\section{Téměř ideální dělení věd}

Vědní obory Ize detailněji rozdělit na základní skupiny podle několika kritérií. Nechám stranou dřívější způsoby, které dnes už mají jen antikvární význam, jako např́iklad dávné antické dělení nebo přísně pozitivistická klasifikace, při níž se za vědy považují pouze ty disciplíny, které dokáží formulovat vědecké zákony a při kterých je možná matematizace.

Podle toho, jakou používají metodu, Ize rozdělit vědní disciplíny na induktivní nebo deduktivní. Induktivně postupoval napríklad Václav Mencl, když na základě poznání tisíců objektů lidové architektury vymezil oblasti s typickým způsobem jejich výstavby (domy srubové, hliněné, hrázděnéz ${ }^{23}$ ). Indukce je tedy vytvoření souhrného uzávěru z řady jednotlivých poznatků. Dedukce naopak znamená usuzování od obecného ke konkrétnímu. Například Mencl se taky zabýval konstruováním typů tam, kde mu již nestačil konkrétní materiál. Uvědomoval si, že „súsek tesaný před našima očima je typologicky starý na dva tisíce let" a pokoušel se vytvořit co najsouvislejší řady typů, na které však ne vždy měl konkrétní stavby a usuzoval o jejich existenci vlastně deduktivně. ${ }^{24}$

Trochu podobné předchozímu je dělení na teoretické a empirické vědy. Ty první jsou blízké deduktivnímu způsobu uvažování, které se spoléhá, podobně jako Descartes, na to, že není třeba vyjít z pracovny a dá se tak uvažováním vytvořit ucelený teoretický celek nebo nový poznatek. Empirické poznávání zdůrazňuje zkušenost, pozorování a experimentování.

Exaktní (nomotetické) a neexaktní (popisné, idiografické) je dělení podle toho, zda dokážou prípadně prostřednictvím umělých formálních jazyků (hlavně matematiky a logiky) vytvořit vědecký zákon.

Normativní a nenormativní je dělení podle toho, zda se stanoví nějaké normy či hodnoty, které jsou uskutečňovány, nebo jsou na hodnotách nezávislé, jako např́klad pojednání o architektuře egyptských pyramid. Normativní je takový výzkum, který si klade otázku „jak by to mělo být?“ Např́klad ten, který Ernest Neufert shrnul ve svém slavném díle z oblasti architektonické typologie Bauentwurfslehre.

Tyto způsoby základního dělení vědy vycházejí ze způsobu, jak věda postupuje při zkoumání čili $z$ vědeckých metod - ty si podrobněji probereme ve třetí kapitole.

Zmíněné souměrné párové rozdělování je však trochu moc abstraktní. Když je potřeba zachytit do systému i okrajové disciplíny nebo nově vznikající hybridní obory, narazíme na různé hraniční prípady, komplikace a nesouměrnosti. Říkám to proto, že podobné nejistoty se zařazením se týkají i vědeckého poznávání ve sféře architektury.

\section{Pragmatické klasifikace vědních oborů}


Organizace pro ekonomickou spolupráci a rozvoj OECD vytvořila pro lepší přehled o financování a zdrojích vědy tzv. Manuál Frascati. Sjednocuje klasifikaci vědních oborů, přesněji řečeno výzkumu a experimentálního vývoje. Na nejvyšší úrovni jsou tu vědní obory rozděleny takto:

1 / Př́rodní vědy;

2 / Inženýrství a technologie;

3 / Lékařské a zdravotnické vědy;

4 / Zemědělské a veterinární vědy;

5 / Společenské vědy;

6 / Humanitní vědy a umění.

Manuál vznikı na setkání odborníků v roce 1963 ve vile Falconiere v italském městě Frascati, po němž je pojmenován. Architektura je zde zcela na okraji (vzpomíná se zde jen jednou, a to jako computer architecture - !). Jediná smysluplná spojitost tohoto dokumentu s architekturou se váže k slavné renesanční vile, kde původně dokument vznikl. (Na jejím projektu se podílel Antonio de Sangallo mladší a Francesco Borromini.)

$\checkmark$ slovenském seznamu vědních oborů ${ }^{25}$ je architektura spolu s urbanismem ve skupině Stavebnictví, která patří do oblasti technických věd. Současně se však objevuje pod názvem architektonická tvorba i v humanitních vědách ve skupině věd o umění.

$\checkmark$ českém seznamu vědních oborů určeném pro nový způsob posuzování výsledků vědy ${ }^{26}$ je podobně architektura rozdělena na inženýrskou Architecture engineering, zařazenou do skupiny Civil egineering, a Architectural design patřící do skupiny Arts. (Paradoxně jsou v českém seznamu anglické názvy.)

O tom, jak plynulý je přechod mezi „čistými“ vědami a učebními obory, dobře hovoří slovenská vyhláška Statistického úřadu SR č. 242 ze dne 3. 8. 2012. Právě takový nečistý mix je protipólem těch zdánlivě krystalicky čirých a od života odtržených klasifikací, pro které je např́klad nestravitelné rozdělení architektury mezi společensko-vědní nebo umělecké či technické a materiálové oblasti. Můžeme s ním být nespokojeni, rádi bychom, kdyby byla architektura umístěna čistěji a jasněji. Ale právě v našem případě to přece umožňuje bohatý výběr výzkumných témat a metod jejich řešení můžeme bez zábran a zdravě anarchicky čerpat z bohatého okolí, kam nás tento seznam přinesený „životem“ zařadil. Zde je výňatek - základní členění - s podrobnějším členěním Technických věd ze zmíněného dokumentu:

1. Přírodní vědy

- fyzika

- matematika

- biologie

- chemie

- geografie

- geologie

- ochrana životního prostředí

2. Technické vědy a nauky I. (ty se zřejmě od II. liší tím, že jsou blíže k přírodním vědám)

- hornictví, geologie a geotechnika

- hutnictví

- strojírenství a kovozpracující výroba I. a II.

- informatika a výpočetní technika

- elektrotechnika

- technická chemie silikátů (tj. sklo, keramika, výroba stavebních hmot)

- technická a aplikovaná chemie

- potravinářství

3. Technické vědy a nauky II.

- textil a oděvnictví

- zpracování dřeva

- polygrafie a média 
- architektura (3507 „architektura a urbanismus“, 3514 „územní plánováni“)

- stavebnictví-geodézie a kartografie

- doprava, pošty a telekomunikace

- automatizace a řízení

- speciální technické obory (např. aplikovaná mechanika),

- atd.

4. Zemědělsko-lesnické a veterinární vědy

5. Zdravotnictví

6. Společenské vědy, nauky a služby I.

7. Společenské vědy, nauky a služby II.

8. Vědy a nauky o kultuře a umění (zde jsou i „8109 dějiny a teorie výtvarného umění a architektury“ $\mathrm{i}$, „8215 architektonická tvorba“)

9. Vojenské a bezpečnostní vědy a nauky

Mezitím se k nám dostaly mezinárodní klasifikace, ve kterých jsou také nejasnosti a pojistky, které dávají prostor pro speciálnější těžko zařaditelné odbory. Zde je ukázka zařazení architektury podle jedné takové klasifikace. ${ }^{27}$

07 Inženýrství / strojírenství, výroba a výstavba

073 Architektura a výstavba

0730 Architektura a výstavba dále nedefinované

0731 Architektura a plánování města

0732 Stavebnictví a stavební inženýrství

\section{Pomocné vědy (historické)}

Často celkem mimo tyto byrokratické struktury uvnitř věd existují zvláštní vztahy a souvislosti, jako např́klad v oboru historie, kde se její různé specializace nazývají pomocnými vědami historickými. ${ }^{28}$ Jsou to části historiografii blízkých vědních oborů, které se danou problematikou zabývají z hlediska dějin, např́iklad historická geografie, historická statistika nebo historická jazykověda. $V$ užším slova smyslu jsou to specializace dějepravy zaměřené na osobité oblasti, např́klad archivistika (zkoumá archivní dokumenty), paleografie (nauka o písmu), kodikologie (o literárních rukopisech), epigrafika (zabývá se nápisy), diplomatika (nauka o úředních písemnostech), sfragistika (zkoumá pečeti), genealogie (nauka o rodech), numismatika (nauka o platidlech), kampanologie (zabývá se zvonařstvím a zvony), heraldika (nauka o erbech a znacích), faleristika (jejím předmětem jsou vyznamenání) či vexilologie (nauka o vlajkách).

\subsection{ARCHITEKTONICKÁ VĚDA}

$\checkmark$ předchozím textu jsem párkrát kromě známých exemplárních př́ikladů z dějin „pravé“ vědy zmínil i několik př́kladů z oblasti architektury. Jak jste mohli vidět, nebyly to nijak vědecky typické př́iklady, často se jednalo jen o základní evidenční poznávání nebo stavění teorií, které se při nejbližším závanu zhroutily jako domeček z karet, nebo přinejlepším zapadly a zůstanou v dějepise jako milá kuriozita.

Někde v celkem zapomenutém pozadí zůstalo např́klad to, co by se dalo označit za typický př́klad sledovatelského, deskriptivního výzkumu. $V$ době, kdy se o antických památkách vědělo poměrně málo a údaje o nich byly jen matné, vyslali roku 1674 Francouzi mladého architekta Antoina Desgodetsa, aby vybrané památky podrobně prozkoumal. Toho sice zajali piráti a drželi jej přes rok v Alžírsku, ale nakonec se dostal do Říma a přesně změřil 24 objektů včetně Panteonu a po cestě zpět ještě i amfiteátr ve Veroně. ${ }^{29}$ Takový vědecký program se dnes v architektonické obci považuje za zcela okrajový, ačkoliv podobné popisné metody používají běžně některé současné vědní disciplíny. Stejně paradoxně prostý až triviální mi přijde výzkum plachých živočichů pomocí fotopastí. 
Přitom je to naprosto standardní a současně populární a atraktivní způsob získávání nejzákladnějších poznatků v dnešní environmentální či ekologicky orientované zoologii.

Úsilí o autorskou originalitu vtisklo podobným architektonickým více nebo měně vědeckým teoriím a manifestům osobitou pečet individualismu, která obvykle vedla k rychlému odsunutí z horizontu pozornosti. Takový byl osud například racionalistického pokusu Le Corbusiera o vytvoření univerzálního proporčního systému Modulor, nebo dílo zmíněného Ernesta Neuferta (1900-1986), který se stal zakladatelem dodnes funkční, ačkoli podobně nespravedlivě na okraj vědeckého zájmu postavené disciplíny, kterou nazýváme typologie, podle svého klíčového díla Bauentwurfslehre, doslova nauka o návrhu stavby. ${ }^{30}$

Jiným typem pokusu o specifickou architektonickou teorii je postižení hlubinných principů, na jejichž základě lze postupovat při přípravě některých typů staveb či jejich částí, prrípadně architektury jako celku. Př́íkladem tohoto je dílo Christophera Alexandra, který vyvinul teorii vzorových jazyků (pattern languages), z nichž odvodil univerzální způsoby výstavby a navrhování. Jak je v architektonických manifestech tradicí, i zde je racionální teoretické poznání zahaleno do rétorického hávu, který vytváŕí kolem jeho teorie „architektonicko-religiózní klima“31 a naléhavě se obrací na ty, kteř́ jsou ochotni jí uvěřit. Tento subjektivní aspekt, typický pro celou řadu podobných architektonických poznávacích děl, ji však odsouvá z pole čistě objektivní a nestranné vědy.

Tyto sofistikované tendence někdy zastiňují mimořádný význam, který pro architekturu má vědecké poznávání v specifické a pro obor velmi významné oblasti architektonické typologie.

Typicky architektonické teorie jsou na hranici mezi uměleckým manifestem a výsledky analytické architektonické historicko-analytické vědecké práce. Je však mnoho drobných vědních disciplín, které jsou na tom podobně nejistě, co se týče jejich vědeckých fundamentů.

\section{Hlavní oblasti architektonického výzkumu}

V oboru architektury se dá zhruba vyčlenit několik oblastí možného výzkumu. Některé z nich jsou perspektivnější, jiné spiše tradičnější, některé jsou možná už z hlediska pronikavého nového poznání vyčerpány. Uvádím je tu, protože tento výpočet může pomoci při formulování zpưsobu řešení tématu disertace nebo při snaze o její zřetelnější zaměření.

$\checkmark$ oblasti které se věnují dějiny umění je důležitou architektonická historiografie, která těsně souvisí s památkovým výzkumem. Přitom je poněkud paradoxně zařazována do skupiny zvané Arts, kde je směs vědních oborů, které zkoumají umělecké výkony (např. Performing arts studies) spolu s uměleckými disciplínami, které takové výkony tvoří (např. Music). Někdy je však architektonický výzkum př́liš ve vleku uměnovědné metodologie a nemá přesněji zaměřený vlastní osobitý způsob zkoumání a nazírání na objekt svého změření.

S celostním charakterem předmětu bádání souvisí zřejmě časté úsilí o jeho souhrnné teoretické uchopení, které má svou dlouhou historii v architektonických teoriích a traktátech. Architektonická biografistika (monografie architektů) zase navazuje na dávnou tradici životopisů významných umělců.

Výzkum architektury v pojetí pozitivně empirickém se např́klad v pojetí časopisu Architectural science review, ${ }^{32}$ který dlouho kultivuje tuto linii výzkumu, zaměřuje na architektonickou vědu, technologii a vystavěné prostředí. Témata, kterým se věnuje, jsou environmentální udržitelnost, konstrukce a materiály, osvětlení, akustika a stavební fyzika, stavební klimatologie, ergonomie, ale i historie a teorie architektonické vědy.

Autorka knihy o výzkumných metodách a technikách v architektuře E. D. Niezabitowska vyčleňuje čtyři skupiny vědních disciplín souvisejících s výzkumem architektury: technické vědy, ekonomii, ekologii a sociální studie. V rámci nich připomíná poměrně široký okruh specializací, například výzkum automatických stavebních kontrolních systémů, stavební ekologii, materiálněenvironmentální ochranu, energetickou úspornost a podobně. ${ }^{33}$

Domnívám se, že možnosti dalšího výzkumu stále poskytují vcelku tradiční architektonické oblasti, jakými je oblast výzkumu dispozice (logika a harmonie funkčního uspořádání), prostoru a jeho kontextu ${ }^{34}$ (prostorový zážitek rozvíjející se v čase; dojem z prostoru na způsob estetickouměleckého, spacialistika), používání (ekvivalent uměnovědná výzkum zaměřeného ne na velkého 
umělce-autora, ale na objednatele uměleckého díla), přijetí, akceptování, opotřebení a ničení. Vědecký přistup k architektuře je trvale ovlivňován její komplexností (architektura je z principu holistická, souhrnná, celková, jiné umění mohou a často záměrně jsou provokativně jednostranná), která stále nabízí možnosti výzkumu. Dále jsou tu společenské (sociální) dimenze architektury a zvykli jsme si jen málo pozornosti věnovat její ekonomické stránce.

Specifickou oblastí je celá sféra urbanismu, kde je idiografické psaní o kráse a umění v pozadí i díky tomu, že jedinečnost zde ustupuje a do popředí se dostává mnohost více umožňující kvantitativní, nikoli pouze kvalitativní výzkum. Nepř́liš dávné je úsilí přibližit se vědeckému světu zdůrazňováním faktu, že určitý způsob poznávání a bádání obsahuje také proces architektonického navrhování a mluví se o výzkumu navrhováním (research by design). Souvisí se snahami celé umělecko-výzkumné-akademické sféry o větší uznání a s tím spojené lepší financování. V tzv. Vídeňské deklaraci o uměleckém výzkumu (AR - artistic research) byl v roce 2020 učiněn pokus o zařazení výzkumu, který probíhá v oblasti uměn a jehož výstupy nejsou jenom standarní vědecké časopisecké články, ale také různé artefakty, pohyby a zvuky, ${ }^{35}$ mezi obory, které mají nárok na podobné financování jako klasické vědní obory a o plnohodnotné zařazení v zmiňovaném Frascati manuálu mezi ně.

\subsection{DOBRÉ RADY NA ZÁVĚR - POPRVÉ}

Věda nejsou jen jistoty, ale i otázky.

Bud'te zdravě skeptičtí a zvědaví.

I narace může být vědecká, ačkoli ji nelze matematizovat.

Pavěda není věda.

Neřešte, kam patří architektonická věda, ale přispějte k její kultivaci dobým výzkumem.

Složitého filosofování teoretiků vědy si nemusíte všímat, ačkoli někdy je nám nakloněno.

Hledejte si svobodně své téma v tradiční nebo aktuální oblasti či na jejich hranicích.

Neopouštějte pole architektury, byt' vás lákají pole jiná, zdánlivě voňavější. 


\title{
2. TÉMA
}

\subsection{VĚDECKÝ PROBLÉM}

Problém často nespočívá v tom, že nevidíme řešení, ale že nevidíme problém.

\author{
G. K. Chesterton
}

Téma disertace se formuje postupně. Oficiální způsob užívaný na našich školách je ten, že téma vypisuje školitel, po složitém schvalování se zveřejní a zájemci se na něj mohou přihlásit. Přijímací rízení probíhá před komisí, ale důležitý je hlas potencionálního školitele. Ten má dokonce právo veta a může uchazeče odmítnout. Takto připravená témata mají výhodu v tom, že mohou být součástí výzkumu školitele a najdou uplatnění v jeho vědeckých projektech. Užitečné však je konzultovat téma se školitelem ještě před jeho vypsáním, at už jde o iniciativu jeho nebo uchazeče. Taková témata jsou často vyhraněnější a mohou lépe směřovat k cíli. Není to však zaručeno. Sebejistota uchazeče bývá někdy větší než možnosti vedoucího práce ji usměrnit.

Po takovém složitém postupu se může zdát, že téma je už definitivní, nic jím nepohne. Ve skutečnosti však nic není vzdálenější opaku - námět a název disertace se upravuje skoro bez výjimky tak, že se záběr zužuje. $V$ oblasti architektury, která si zakládá na své klasické celistvosti, se témata na získání uchazečů s oblibou formulují široce. To lépe přiláká uchazeče, jež úzce a detailně formulovaná témata odrazují a cítí se jimi omezení v rozletu. Až postupně se ukazuje, že není v silách jediného začínajícího badatele postihnout záběr tak široký, jaký původně formulovaný název lákavě nabízel.

Šiř́ka a neurčitost oboru architektury může vést $\mathrm{k}$ otázce, které téma je vlastně vědecké v pravém slova smyslu. Přísně vzato se za taková považují ta témata, která mají zmíněné vědecké parametry a jejichž výsledky Ize testovat verifikováním nebo je podrobit kritice či falzifikaci kompetentním způsobem. $Z$ vědeckosti se například sama vylučují témata, za nimiž podle pavědecké teorie stojí nějaké údajně neměřitelné nebo běžnou vědou neuchopitelné příčiny. Například údajné „energie“, se kterými operuje feng šuej a podobně. Hranice, kde se již bádání v oblasti architektury pohybuje mimo sféru vědeckosti, je však málo ž̌etelná a úsilí vtáhnout do výzkumu i proces navrhování ji ještě víc rozptyluje. Určitě je však vhodné sledovat alespoň obecné požadavky na vědeckost, to znamená otevřenost poznávání skutečnosti, jasnost metod, opakovatelnost a př́stupnost vůči diskusi ve vědecké komunitě.

\subsection{VÝBĚR TÉMATU}

Disertace může být vysoce filosofická anebo vysoce empirická, ale vždy musí být o něčem. I. BORDEN, I., K. R. RÜEDI

\section{Formulování a uchopení tématu}

Standardní úřední postup, jakým se téma zveřejní, ještě není zárukou, že se vůbec najde zájemce, který se o něj přihlásí. To může způsobit těžkost tehdy, když má být řešení daného problému součástí nějakého rozsáhlejšího projektu, navíc ještě i termínovaného.

Disertant se však může postupně zmocnit svého tématu různými způsoby, přičemž do určité míry hraje roli i jeho osobnostní naturel. Ten se totiž také promítá do výsledné podoby práce a jeho specifika je dobré při zpracování tématu využít. Někteři doktorandi mají totiž svým založením bliže k teoretickému př́stupu, jiným pomůže k uchopení problému to, že se ponoří do drobné práce, z niž postupně vyroste finální produkt. Vyskytují se tři extrémy v individuálním přístupu $k$ řešení disertace: ${ }^{36}$ 
1 / Velcí teoretici mají představu, že potřebují uchopit přinejmenším všehomír a dají se cestou budování velkých teoretických řiší s pochybným vztahem $\mathrm{k}$ realitě nebo aplikovatelnosti. Často je $\mathrm{k}$ této představě přivádí celostnost architektury a tradice traktátů a manifestů, která svádí $\mathrm{k}$ tomu, aby k ní podobným způsobem přispěli.

2 / Všechno a nic je výsledek práce těch, které to podobně jako velké teoretiky táhne k teoretizování, ale pochopili, že všechno se vším souvisí a nedokáží si vyčlenit na hlubší výzkum své vlastní téma. Výsledek je povrchní. Už na počátku k tomu vede příliš široký záběr původního námětu, který si nedokáží zúžit a prohloubit. Svádí je i charakter dosavadního studia, které bylo zaměřeno více na poznání velkého celku než izolaci drobného problému. Správným cílem by mělo být ríct hodně o málu a odolat pokušení ríci málo o hodně věcech.

3 / Zjednodušující induktivismus je ve výzkumu architektury méně častý jev, přičemž se dokonce dá využít při postupném odklonu disertanta od nadměrného sklonu $\mathrm{k}$ předchozím dvěma postupům. Spoléhá se na to, že se postupně ze získaných dat vynoří nějaký závěr, teorie nebo řešení. Induktivisti někdy propadnou okouzlení z množství konkrétních případů - např́klad architektonických objektů, které se jim nabízejí k studiu - a príliš spoléhají na vypovídací hodnotu velkého množství proměnných o nich. Opačný extrém je, že se předpokládá reprezentativnost jediného př́padu: ten údajně rovněž obsahuje zkoumané struktury, stejně jako libovolně velký počet př́padů, a tedy stačí si ho jen dobře zvolit.

\section{Milé téma}

Téma si třeba vybírat tak, aby bylo řešiteli i emocionálně blízké a odpovídalo nejen jeho odborným, ale i osobním zájmům. Jednou z hodnot vědy totiž je také „ legrace zvaná intelektuální potěšení, kterého se některým lidem dostává při čtení, učení a přemýšlení o (vědě) a jiným při práci na ní. " ${ }^{37}$ I takové „milé“ téma však bývá předmětem těžkých zkoušek v době váhání nebo při závěrečné depresi, kdy se třeba mořit s posledními mechanickými pracemi na disertaci a celá disertace je už svému autorovi více než odporná.

Téma přitom nemusí být sympatické jen svou primární líbivostí, ale takřka i nějakou vnitřní výzvou. Pavel Halík, který nepochybně názorově stojí na pravé straně politického spektra, se např́iklad s obdivuhodným zápalem a nadšením věnoval tématu dost „nemilému“ - tomu, jak architekti podléhali stalinistickému tlaku a ztotožňovali se se socialistickým realismem. Touha po poznání této zvenčí sotva sympatické věci byla silnější a překonala i primární nepř́ivětivost.

\section{Zájmy disertanta}

Pro většinu uchazečů bude sice vědecká práce na disertaci ucelenou a uzavřenou etapou života a věde se již věnovat nebudou, ale dá se předpokládat, že poznání, které při práci na disertaci získají, bude hrát nějakou roli v jejich dalším pưsobení. Zřetelnější to je u těch, kteří pracují v oborech, kde se podobné zvyšování kvalifikace víceméně očekává, například ve sféře ochrany památek. Projektující architekti mají tendenci volit si spíše obecně teoretická témata v duchu dvoutisícileté tradice architektonických teorií, tedy směsici filozofujícího uvažování nad vlastní tvorbou a formulováním autorského kréda. Pro ně je disertace přiležitost vystoupit z mechanického kolotoče praxe a zformulovat syntézu svého individuálního poznání tak, aby byla podrobena i určité objektivní korekci ze strany školitele a školícího pracoviště. Měli by si však uvědomit, že se dostávají do role „žákư“, vůči nimž učitel uplatňuje i tradiční učitelské autoritativní nároky, v běžném životě neobvyklé.

Při výběru témat se sice spíše stane, že se zvolí módní námět, ale vyskytuje se také skrytější problém, a to je tendence konzervativní: vybírat problém z oblasti, která nám je známá a kterou proto automaticky upřednostňujeme. Známým informacím totiž připisujeme vyšší důvěryhodnost než novým. Podobně máme tendenci upřednostňovat to, co si v paměti spíše vybavíme.

\section{Dostupnost pramenů}

Riskantním při formulaci tématu je předem ne zcela jasná dostupnost pramenů, od kterých se bude odvíjet. Když se výzkumný problém postaví dostatečně inovativně, nemusí být jisté, že se narazí na přiměřeně výpovědní zdroj informací. Doktorandi mají často představu o nezbytné originalitě své 
práce, ale mohli by se někdy více zaměřit na opětovné využití stávajících a již jednou použitých zdrojů, např́klad na ty, s nimi již pracoval jejich školitel. Petr Urlich s kolektivem např́iklad zachytil $v$ rozhovorech názory významných architektů a teoretiků, ${ }^{38}$ a ty by bylo možné podrobit s odstupem času jinak zaměřené analýze. Potíž vězí v tom, že ve výzkumu architektury se dost bazíruje na originalitě, a to se promítá i do úsilí mít originální nové zdroje informací.

Moje doktorandka Veronika V. se zabývá uměleckými díly v architektuře do roku 1989 a předpokládali jsme, že se dostane k nějakým záznamům z komisí, které tato díla vybíraly a schvalovaly. Mezitím se naskytla možnost zjistit pozadí těchto procesů, jak si je pamatovala administrativní pracovnice této komise. Oba zdroje informací byly v čas vypsání disertace jenom dohadem, který bylo třeba $v$ průběhu práce ověřit. Ve starší práci na podobné téma, kterou jsem měl možnost konzultovat, jsem její autorce navrhl zkusit odkrýt pozadí zmíněného procesu schvalování na základě rozhovorů s jejím otcem, významným sochařem. Tak by mohla objasnit nejen mechanismy tvưrčí blízkosti a osobních přátelství, ale i neoficiální finanční vztahy mezi architekty a výtvarníky.

Často se zdá na počátku jasné, jak bude výzkum vypadat a zdrojové informace hledáme podle jeho zaměření. Charakter dostupných pramenů však často zpětně způsobuje úpravu nebo zpřesnění tématu. Nejen dostupnost, ale i výběr a vyčlenění faktů, které na realitě zkoumáme, jsou důležité. To vše má tvořit přiměřeně ucelený, logicky definovaný systém, který dává záruku, že závěry, které z nich v práci zformulujeme, jsou smysluplné a nestojí za nimi nějaká jiná neidentifikovaná př́čina.

\section{Klam úspěšných}

Při výběru témat často začínáme pracovat s lehce dostupnými prameny. V určitém stadiu má však smysl zkusit konvenční výklad originálně obrátit a zformulovat otázku, jakou dosud nikdo nepoložil. I při výběru úspěšných řešení nebo vynikajících osobností jako vzorů se může stát, že podlehneme konvenčnímu pohledu. Psychologové znají tzv. klam přeživších, při kterém se odvozují řešení pouze z úspěšných situací. Často se to ilustruje na príkladu z druhé světové války, kdy Američané zkoumali poškození svých letadel, která se vrátila z bombardování a zvažovali lepší opancéřování zasažených částí. Přizvaný matematik je však upozornil na chybu, kterou dělají: usuzují podle zásahů na strojích, které se úspěšně vrátily. Ale ty byly poškozeny právě na méně důležitých místech - vždyt' se přece dokázaly zachránit. Úpravy by si zasloužila právě nepoškozená místa, což by nejlépe bylo vidět na sestřelených letadlech.

Klam přeživších je usuzování podle skupiny jevů, které již prošly nějakým výběrem, aniž by se dělaly závěry také podle odsunuté části a zohlednila se celá skupina. Oblíbené je například předkládání osudů úspěšných lidí, jako následováníhodných vzorů. Užitečnější by však bylo poučit se $z$ chyb neúspěšných. Ty ale nikdo jako vzory nepředkládá. Psycholog D. Kahneman řekl, že „pokud dáme všechny úspěšné dohromady a budeme hledat, co je pro ně společné, jedinou opravdovou odpovědí bude - štěsti".

V tomto světle je sporné, zda např́iklad náš soubor životopisů významných českých architektů působících na Slovensku ${ }^{39}$ není právě o těch štastnějších a zda Ize něco vyvodit jako ponaučení z jejich života, zápasů a tvorby. Možná je to prostě jen vyprávění lidských přiběhů, idiografické líčení, které nás pritahuje svým magickým kouzlem, nic víc.

\section{3 ŠÍŘKA A ZAMĚŘENÍ}

\section{Zpracovatelnost a metodologická pripravenost}

Téma disertační práce je podmíněno i schopností disertanta je zpracovat. Obvykle je to spojeno s osobními dispozicemi. U někoho převažuje sklon $\mathrm{k}$ obecně teoretickému uvažování a dotyčný se nechce př́liš zatěžovat fakty (podle jednoho Murphyho zákona, který ŕíká, že „věda má vždy pravdu, nenechte se svést fakty“), někdo raději usilovně pracuje s množstvím dat, ale často z nich nedokáže vytvářet syntetičtější závěry. Tyto dispozice nejsou na počátku prací zřejmé, a i pilní induktivisti se často zdají být syntetiky, nebot' se nejprve pracuje na obecné úrovni formulování výzkumných cílů. 
I to, do jaké míry dokáže disertant ovládnout př́padné speciální metody, je zpočátku nejisté. Zúčastnil jsem se obhajoby, kde prezentující zadal vypracování triviální statistické analýzy zkoumaného jevu někomu jinému, a dokonce se ani netajil svým distancem vůči tomu, aby si osvojil elementární základy statistiky.

\section{Široký přehled nebo hluboká monografie?}

Pokud je téma př́liš široké, vede $k$ povrchnosti, zvláště pokud se skládá z více částí, při kterých se problém jen povrchně analyzuje a chybí hlubší inovativní ponor. Zúžení prakticky každého tématu je výhodné a rychleji vede $k$ cíli. Přehledová široká témata mají smysl tam, kde jde o evidenční uchopení problému. Ve Výzkumném centru průmyslového dědictví FA ČVUTvznikala doktorská témata, jejichž autoři měli zmapovat například všechny někdejší cukrovary na území ČR. Databáze, která takto zachycuje celou řadu historických průmyslových objektů, je velmi ceněná a v dalším výzkumu se na takovém faktografickém základě dají zkoumat užší otázky, například koncepce obnovy těchto objektů a podobně.

Opakem širšího přehledu s množstvím aspektů nebo objektů je monografie čili práce, která se hluboce soustřed'uje na jeden jediný objekt nebo předmět. V prvním př́ípadě byl požadován úplný rozsah, zde se naopak očekává co možná nejhlubší možný ponor. Pojem monografie se dnes trochu rozostřil tím, že se za ni považuje jakákoliv knižní vědecká publikace stanoveného rozsahu. Původní význam slova mono v jejím názvu však stále vypovídá o tom, že se zabývá jednou věcí.

\section{Teoretické, empirické nebo experimentální téma}

Už jsem se zmínil o tom, že architektům je blízká holistická tendence chápat věci vcelku a uvažovat nad nimi synteticky a obecně, nikoliv analyticky. Většina témat disertačních prací má obecně-teoretický charakter a jejich plodem jsou takříkajíc traktáty. S menšími sympatiemi se setkávají analytická témata, která vymezují na zkoumaném objektu úzký segment problémů. Vyčíá se jim někdy tendenčně, že uměle vysekávají z reality nějaký proces nebo stránku, na kterou působí významné proměnné i mimo vymezený systém - vždyt' architektura je složitě sestavený celek. To také vede $\mathrm{k}$ podceňování témat, která by se dala řešit experimentální metodou. Experiment je v přirozeně složité soustavě, jakou je architektura, těžko realizovatelný. Nedají se dobře udržet stabilní vnější podmínky a cílené řízení sledované veličiny. Přesto jsou možná i taková témata, která by se experimentováním řešit dala.

\section{Současnost nebo minulost?}

Téma se může zabývat aktuálními jevy a procesy bez ohledu na to, jak probíhaly v minulosti. Může se však také zabývat minulostí a jen předpokládat, že něco ze získaných poznatků může mít smysl pro dnešek. Může však zůstat i v rovině vyprávění nějakého minulého příběhu. Oblast architektury poskytuje široké možnosti v jedné i druhé sféře. Určitě je také možné uvést problém na základě jeho historické relevantnosti a pak se mu věnovat v rovině dneška. Když se jen neurčitě propletou oba prístupy, hrozí, že výsledek bude povrchní.

\section{Normativní nebo deskriptivní téma?}

Aktuální téma poskytuje možnost vyvodit z výzkumu normativní závěry. Dokonce je to v oboru architektura velmi častá tendence. Do textů o architektuře publikovaných u nás v 50 . letech se promítla spolu s ideologickým tlakem i osvětově-vzdělávací povinnost, která se projevila v množství hodnotících soudů a výroků o tom, jestli je dané řešení správné nebo ne. Dnes se zase tvrdí, že architektonická kritika je málo kritická - ve smyslu odsouzení nesprávných řešení.

Bez ohledu na opodstatněnost těchto trendů je hodně disertací zaměřených normativně. Jejich autoři usilují formulovat správné řešení, a často i postup, jak k němu dospět. Vždyt́ nakonec takové jsou i klasické architektonicko-teoretické traktáty a v celé oblasti architektonického projektování je také množství limitů, norem, předpisů, příkazů, kontrol správnosti přicházejících ze světa realizační praxe, jaké se v jiných vědních oborech vyskytují jen málo anebo vůbec ne. Řada disertací pak podle toho i usiluje podat praxi nějaký návod, metodiku, postup, jak správně projektovat dané objekty, jak 
ochraňovat tu kterou památku a podobně. Čirá deskriptivnost, opis, vyprávění př́běhu nebo konstatování nějakého typu závislosti se považují za nedostatečné.

Při formulování podobných doporučení a metodik bud'te opatrní, abyste nezůstali naivně pouze na povrchu, aniž byste postřehli komplexnost překážek stojících v cestě jejich realizování. Hluboké postižení problému nezaujatým teoretickým způsobem může být v praxi užitečnější a mít mohutnější dopad než naivní metodiky, kterými se architekti-praktici př́liš nehodlají ŕídit.

\section{Spojitost či nespojitost s prací a výzkumem školitele}

Jelikož téma vypisuje školitel, předpokládá se, že je s ním nějak spojený a souvisí s jeho výzkumnou prací, že vyplývá z jeho vědeckého zaměření nebo z jeho aktuálního vědeckého projektu. To má výhodu v tom, že téma je už podrobeno určitému vědeckému testování v procesu akceptování návrhu. Školitel vyčlení neznámou oblast, kterou potřebuje prozkoumat, a podle toho vypíše doktorandská témata. Uchazeč se smyslupIně účastí projektu a skutečně přichází na něco nového, dosud neznámého i samotnému školiteli. Nevýhodou z hlediska školitele může být, že se na téma nikdo nepřihlásí, anebo že se disertant nedokáže vpravit do harmonogramu projektu.

Školitel může vypsat i téma, jehož souvislosti velmi dobře zná. Je otázka, zda je to pro doktoranda výhodnější - školitel ho sice snadno může převést přes nástrahy tématu, ale pocit nového výsledku se ztrácí.

$\checkmark$ př́padě absence vazby na nějaký probíhající výzkum se vyskytuje ještě jedna možnost, kterou je vypsání volně generovaného tématu „vycucaného z prstu“, o kterém ani školitel nemá jasno, nejen co se týče jeho výsledku, ale ani co do metody a smyslu. Takové voluntaristické téma je však lákavé, nebot' často naznačuje jakousi spojitost s nejsoučasnějšími mlhavými otázkami, které se právě v oboru vynořují. Jejich vědecká nosnost je však sporná a vyžadují hodně práce na upřesnění a hledání zdrojů informací. Hrozí při nich, že kouzlo jejich novosti vyprchá ještě před dokončením disertace. Jedna moje doktorandka se dala zlákat tématem Podnikatelské baroko. Nejdřive zvážila a zamítla teoretickou analýzu kýče, potom řešila problém, jak se věrohodně přetvařovat, když komunikuje s majiteli rodinných domů postavených v duchu podnikatelského baroka. Nakonec už jen zjistila, že se tento, pro architekty úpadkový, trend, již vytrácí a nedají se z něj vyvodit žádné závěry, a to ani na podporu Horáčkova ${ }^{40}$ horování za krásnou architekturu.

\subsection{ARCHITEKTONICKÁ TÉMATA}

Kritérium vědeckosti v architektuře je poměrně volné, témata výzkumu se zde nabízejí ve velmi širokém záběru od společensko-humanitární oblasti přes přírodovědné a technicko-vědní zaměření, témata teoretická i empirická, zaměřená na řešení aktuálních i historických problémů. Neurčitost a rozpačité zakotvení vědecké práce $v$ architektuře má důsledek, že je široký i záběr témat, která se jí týkají a mohou být vtažena do sféry poznávání.

Zvláštní částí je problematika vztahu témat k vlastní architektonické tvorbě. Objevilo se úsilí etablovat tzv. výzkum navrhováním mezi vědecké metody. Staví na tradičním spojení empirie a teorie $v$ architektonických traktátech a na důvěře $v$ poznávací procedury přítomné ve vlastním architektonickém navrhování a projektování. I když nemusí být zdůvodnění tohoto typu výzkumu dostatečně přesvědčivé, vychází z přesvědčení o nezbytnosti spojení poznávací a návrhové složky $v$ architektonické tvorbě. Otázka je, zda oboru více neprospěje lépe se profilovat zdola, induktivním způsobem, například i prostřednictvím koncipovaně postavených témat disertačních prací a odpoutáním se od vzorů témat z blízkých disciplín, napríklad i z oblasti dějin umění nebo speciálních technických oborů spojených se stavbou a stavěním.

\section{Standardní okruhy témat}

Hlavní odlišností, kterou se vyznačují témata formulovaná v oboru architektura, je to, že jsou postavena více objektově než problémově. Obvyklé téma tedy zní: Jak (správně) navrhnout dům, ne Co o tom (domě) nevíme? Mohlo by se to zdát na první pohled chybou, a skutečně, často to i vede 
k nedostatečné analýze a ke sledování stereotypů, zdůrazňování standardních, konvenčních, málo objevných postupů, $\mathrm{k}$ osvětě a $\mathrm{k}$ nadměrnému důrazu na reglementování správného postupu a podobně. Ve skutečnosti však takto stavěné téma vlastně odráží základ profese. Ta totiž nemá poznávat, ale vytvářet. Jistěže je uvnitř skryté hlubší poznání, tj. co všechno třeba znát a jaké nové poznatky jsou nutné k tomu (správnému) navržení onoho domu.

Když jsem však prošel témata disertací obhájených na našich architektonických školách (na ČVUT v Praze a STU v Bratislavě) za poslední roky, našel jsem tam i taková, kde se za zmíněnou objektovostí dalo tušit i nové poznání.

\section{Témata ze současnosti}

$\checkmark$ tématech zaměřených na aktuální problémy se jejich objektovost promítla do doporučení, jak správně navrhnout dané architektonické objekty. Někdy je ve formulaci téma skryté takto: Architektura školy architektury. Jindy se objevuje takříkajíc „funkční" specifikace témata: Architektonické řešení krbů a kamen jako alternativních zdrojů tepla. Častá je široce sociální či zdravotní specifikace, jako napríklad při tématu: Zlidštění ubytovacího úseku v zařizeních sociálních služeb pro lidi v hmotné nouzi, nebo zaměření kontextové: Sakrální architektura. Tvorba ve vztahu $k$ historické struktuře.

Jen velmi zřídka se vyskytne situace, že je výsledkem disertace nejen traktát, ale také navržené, resp. dokonce realizované dílo, a to dílo, které úspěšně snese aktuální architektonicko-umělecká kritéria. Př́kladem je disertace, která nabídla architektonicky kvalitní návrh koncertních sálů pro Prahu s názvem: Koncertní sály. Disertace s názvem Harmonikum. Temperovaný proporční systém vyústila nejen do knízky První dům, ale také k malému dřevěnému domku, který autor i postavil na základě proporcí zlatého řezu a Le Corbusierovho Moduloru.

To, že výsledkem disertace je jen výjimečně realizované umělecké dílo, je způsobeno tím, že jde o převážně mladé doktorandy, kteři ještě nemají oprávnění samostatně projektovat. Pokud se i soubor realizovaných děl předkládá, jde často o realizace, které prošly komplexním procesem a neodpovídají tomu, co se při disertaci přirozeně předpokládá, $\mathrm{tj}$. analytickému redukování na podstatné vybrané či vypreparované jevy. Tak např́iklad zmíněný dřevěný domek se stal předmětem parciální kritiky za nedostatky, které vyplynuly ze zvolené ústřední myšlenky - že je navržen podle apriorních matematických měřítkových kritérií.

$\checkmark$ uvedených tématech je v pozadí normativnost. Nejde o nezávislé chladné přezkoumání jevu, napríklad jako to bylo s těmi krby nebo kostely, jaksi mimo nás, ale zde se vždy klade otázka, jak je to $s$ danou stavbou vưči hodnotám, které vyznáváme. Taková témata jsou vždy stavěna normativně, tj. jak je to pro nás vzhledem na naše dnešní poznání nejlepší možné. Někdy je v takovém objektověnormativním tématu prímo obsažen odkaz na následováníhodný, zpravidla zahraniční vzor: Cohousing: Analýza dánských bytových souborů, nebo je ten vzor skrytý v pozadí: Aktuální trendy $v$ architektonické tvorbě aquaparků. I v zmiňované disertaci Koncertní sály je obsáhlý rozbor nejlepších zahraničních realizaci koncertních sálů.

Zvláštní normativní kolorit mají práce, které širíi poznatky sice v odborném nebo vědeckém světě známé, ale u nás nejsou ještě dostatečně rozšířené a nedošly ještě k legislativní stabilizaci. Takový specificky „osvětový etos“ mají často práce týkající se architektury pro zdravotně postižené nebo nějaké jiné menšinové skupiny uživatelủ, například témata: Děti a město: Veřejný prostor města s ohledem na děti a mládež.

V oboru architektura získal pojem typologie význam mírně odlišný od toho, jaký má v jiných vědních disciplínách - možná více praktický a méně sofistikovaný. Typologie jako nauka a klasifikace funkčních druhů architektonických objektů je důležitou oblastí, ve které se formuje velká skupina témat disertací, resp. výzkumných témat. Například témata jako Proměny městských hotelů nebo Typologie hospice a souvisejíci problematika. Do této oblasti patří i speciálnější témata, která se věnují analýze otázek dispozice čili typicky architektonického problému. Například: Proměna prostorového uspořádání bytu v období postsocialismu; Interiérový design jako terapie; Personalizace bytového interiéru z hlediska jeho dimenzí. 
Blízko $k$ př́rodovědně-technickým sférám a tím snad i k metodám nomotetických věd má oblast zkoumání stavebního materiálu: Profesionální užití slámy v architektuře; Sklo jako moderní konstrukční materiál; Aplikace nových materiálů při konverzi vybraných objektů elektráren / Na přikladu použití aerogelů při obnově cihlových průčelí nebo zkoumání konstrukcí: Inovativní dřevěné konstrukce; Krycí konstrukce torz architektury; Prvky trvale udržitelné architektury: stínění jako architektonický prvek, resp. zkoumání světla, barvy a pod.: Barva v obřadním prostoru; Zhodnocení významu barevnosti pro výslednou výtvarnou kvalitu interiéru. Zde se výzkum dostává často na hranici př́buzných stavebních vědeckých disciplín a někdy přejde přímo do jejich sféry záběru.

Umělecká rovina profese architekta a s ní spojený pocit umělecké výjimečnosti způsobuje, že se méně vyskytuje zpětná vazba vůči uživatelům objektů, kteří se často soustřed'ují pouze na jejich nedostatky nebo prosazují laický, pokleslý vkus. Zřejmě proto je i takových témat málo, např́klad: Interakce mezi budovou a uživatelem v čase na př́kladu objektu ABX v Praze; Podnikatelské baroko: naivní historizující tendence $v$ rezidenční architektuře na území České republiky v letech 1990-2015.

Zvláštní kategorii tvoří parametrické projektování a s ním spojená specifická témata, která používají v obecném jazyce méně běžné termíny a při kterých se také objevuje moment sledovatelského zkoumání, podobně jako při popisně normativních tématech: Chaotické struktury skrytá logika emergentních systémů na platformě parametrického navrhování architektury.

Témata, která se soustřed'ují na profesi architekta, směřují jednak dovnitř: Význam a role skici $v$ současné navrhování a prezentaci architektury, a jednak směrem ke společnosti: Architekt $v$ mediální síti; Role architekta v řešení společenského začleňování mladých lidí ohrožených bezdomovectvím. Sem patří i témata normativní povahy, jako jsou různé legislativně-správní výzkumy a pokusy o stanovení postupů, metodik a procedur nějak souvisejících s architekturou nebo urbanismem.

\section{Minulost}

Velkou a ucelenou skupinou tvoří historiografická témata týkající se poznávání minulých dějů. Ta jsou sice často také „objektová“, ale stojí mimo normativnost, jinými slovy nelze z jejich poznatků odvodit nějaké doporučení či zákonitost, která by měla platnost přírodního zákona. Zde se disertace pohybují ve sféře vysvětlování, porozumění a narace a neposkytují nám návody pro současnost ve smyslu např́klad správného návrhu krbu nebo koncertního sálu. Jsou to témata jako Středověké vesnické kostely v horšovském arcivévodství nebo Drevěné artikulární a toleranční chrámy na Slovensku či Architektura divadelních budov na Slovensku. Jejich prospektivní výpovědní hodnota se neupřesňuje, ani když jsou soustředěny na jeden jediný objekt: Středověký městský dům v Mladé Boleslavi (ačkoli zde je singulár spíše obrazný) nebo Vývoj urbanistické struktury města Žiliny v letech 1918-1948. Někdy se stane, že tu je skrytý i architektonický návrh nového řešení, jako to bylo v disertaci Moderní architektura jako památka. Budova Slovenského rozhlasu v Bratislavě, ale samotná historiografická část je zde vyprávěním o přípravě a vzniku objektu a nepřináší žádné návrhy nových řešení.

Někdy mají tato témata tendenci směřovat $\mathrm{k}$ prosté evidenci, která by se $\mathrm{v}$ náročnějším vědeckém prostředí považovala za nedostatečnou. Například Historické pivovary Kolínska. Ale když je práce součástí širšího a strukturovaného výzkumu, má takový produkt takříkajíc vědce-začátečníka svůj jasný smysl. Někdy Ize z názvu vyrozumět i to, že jde o víc než jen základní evidenci: například Architektonická činnost ateliéru Fellner \& Helmer na území dnešní České republiky. Do zkoumání minulosti patří i témata, která se věnují období a stylu, například: Šírení funkcionalismu Československá meziválečná architektura Užhorodu; Pronikání anglického parku do francouzské zahrady v českých zemích; Manuelská gotika a její vztah k pozdně gotické architektuře ve střední Evropě, témata zabývající se biografií osobností: Život a dílo architekta Josefa Mareka (1889-1966) anebo Artur Szalatnai-Slatinský. Př́běh bratislavského architekta.

Ale normativnost se i zde přece jen objevuje, a to v podobě formulace zásad nebo více či méně striktních norem památkové ochrany, často formulovaných jako „metodika“: Sakrální architektura. Tvorba ve vztahu k historické struktuře; Památková obnova zámků; Metodika průzkumů a prezentace kulturního dědictví; Uplatnění kopie jako specifické metody prezentace zaniklých kulturně-historických 
hodnot historické architektury. Úsilí formulovat pokyny nebo doporučení někdy odsune možnost odkrýt v názvu i nějaký související obecnější problém, který se bude řešit, jak se to zdá být v názvu: Nadbytečné kostely a velké kaple křest'anských církví na Slovensku.

\section{Úvahy a teorie}

Samozřejmě, že holistický, celostní charakter architektury vede i k úvahovým narativním či filozofujícím tématům, která by v jiných oborech působila nejspíš nenáležitě (Úloha anorganické chemie $v$ dnešní postfaktické společnosti?). Často jsou založena na zkoumání problému v minulosti a ve vytváření teoretické konstrukce na základě úvah: Vztah člověk-dům-strom; Architektura a smrt $v$ teorii a praxi; Architektonické externality nebo jak se dělá architektura.

Někdy se autoři odváží zkoumat to, jak se duch doby (Heglův Zeitgeist) projevil v architektuře (např. v disertaci Fenomén souvislého prostoru). ${ }^{41}$

\section{Specificky architektonická varianta disertace}

Nejistoty spojené s definováním vědního oboru architektura se přenášejí i do okruhu toho, co se nabízí k disertačnímu zpracování. Přitom by obor mohl být zaměřený přesněji a mohl by vnést více specifik do tohoto rejstříku témat nebo by se tato témata mohla zkoumat způsobem, který je bližší architektuře a procesu návrhu architektonického objektu. $O$ to, více vtáhnout vlastní architektonické navrhování, usiluje trend pojmenovaný „výzkum navrhováním“ (research by design). Neměl by však znamenat masivní ústup od verbálně-textové podstaty disertačních prací, která sice není v centru práce projektujícího architekta, ale jejím způsobem se obecně dá tlumočit racionálně-poznávací obsah nejlépe. Podobné to je i v jiných oborech, vždyt' v klinické medicíně se také nečeká provedení operace jako disertace, ve stavebnictví je rovněž předmětem oboru stavění, ne psaní textů, přesto se závěrečné práce píší, nikoliv stavějí. Poučením však může být umělecké doktorské studium, kde se vedle uměleckého výkonu předpokládá i textově-analytická část disertace.

Studenta studujícího dějiny maliřství nikdo nezkouší z toho, jestli umí malovat. Výstupy z jeho práce jsou skoro výhradně jen texty. Architekt-doktorand se však finálně rovněž vyjadřuje textem, nikoliv projektem a realizací domu. Má to být věrný ekvivalent toho, co má vytvořit historik architektury? Nemohu se zbavit přesvědčení, že by zde měla být př́tomna určitá specifičnost, že vedle textu - nebo jako vtipně ríká Petr Kratochvíl - traktátu, by zde mohl být přítomen i nějaký segment inženýrsko-uměleckého neboli architektonického návrhu. Obor by zde mohl méně ustupovat ze svých specifik a kopírovat modely jiných oborů.

\section{Pasti}

Příklady, které jsem v předchozím textu vybral, ilustrují hlavní skupiny témat, jak se na našich univerzitách zadávají. Vznikají tak hodnotné práce, ale uvedené skupiny mají i své stinné stránky a hrozí některé pasti nebo slepé uličky:

- Teoretizující témata upadnou do negativního extrému tak, že filosofování a láska $\mathrm{k}$ mudrováním vedou k jalovým úvahám o všem typu: „architektura je matka umění“.

- $V$ českém prostředí se s oblibou sahá po existencialisticky laděném filozofovaní (že by z piety k rodákovi Husserlovi?).

- Při některých tématech hrozí osvětová trivialita, tj. potřeba jenom opakovat a hlásat základní pravdy, at' už tématu všichni rozumějí, jako například opatřením pro hendikepované, tak také při těch, kterým se rozumí málo, například finesám parametrického projektování.

- V památkářské sféře často převáží přikazování a „metodikování“ (pojem, který jsem skutečně slyšel).

- Disertaci je pouze výsledkem „výletu a rešerše“, jak to jednou vystihl Petr Vorlík.

- Nebo je jen enumerací zářivých, vzdálených a idealizovaných zahraničních vzorů.

- $V$ obdivu k sofistikovanosti umělecko-historického diskurzu se neuměle napodobuje.

- Holistický charakter architektury nedovolí hlubší analýzu, jen povrchní nebo umělecky tendenčně zbarvené filosofování. 
- Přenechává se stavebním inženýrům veškerá starost o architektonické prostředí, o jeho fyzikální, světelnou, tepelnou i akustickou stránku.

- Pohrdá se drobnou vědeckou prací, která předchází formulaci stavební normy.

- Dizertace je jen obdivným životopisem údajného velikána.

- Nebo zůstane jen při popisu minulosti a nic víc.

- Odbočí zcela mimo pole architektury.

- Autoritativně se předpisují legislativní systémy, vyhlášky nebo zákony.

- Disertace je jen a jen subjektivním uměleckým artefaktem bez ambice zobecnit nějaké poznání.

- Mluví jen „jazykem našeho kmene“ - tj. způsobem pro jiné záměrně málo srozumitelným.

- Podlehne svodům nějakých na pohled efektních, ale už vyčerpaných témat (sakrální prostor, osvícený investor apod.)

\subsection{DOBRÉ RADY NA ZÁVĚR - PODRUHÉ}

Zvažte, zda jste induktivní včelička nebo filozofující teoretik.

Formulujte si problém, který jdete řešit tak, aby mu rozuměla vaše babička.

Téma zužujte a zužujte.

Zkuste sáhnout do středu, ne na okraj oboru architektura.

Máte rádi své téma?

Najděte si dobré zdroje faktů.

Vyhněte se konvenčním formulacím problému.

Lepší je hlubší ponor než jalová osvěta.

I osvěta může vycházet z nového poznání.

Namísto popisu objektu řešte jeho problém.

Zkuste něco navrhnout, realizovat.

Když už popis velkých vzorů, alespoň uved'te, jak je u nás aplikovat.

Experiment je sice jednostranný, ale poznatky z něj jsou jen a jen vaše. 


\section{METODA}

\section{Metoda a metodologie}

Metoda je slovo pocházející z řečtiny a znamená cestu někam. Je to vědomý a záměrný postup, jak dosáhnout nějakého cíle, at' už ve vědě, nebo v praktické činnosti. ${ }^{42}$ Pod pojmem metodologie se ve vědě rozumí souhrn pravidel a norem podmiňujících způsob činnosti. Je to tedy disciplína, která se systematicky zabývá metodami, jejich tvorbou a použitím v určité vědní oblasti.

Zatímco tam, kde se běžně kvantifikuje, je vlastní metodologie posunuta spíše do roviny metodiky a techniky zkoumání, v těch oborech, které zkoumají jen kvalitativně, je metodologie důležitější. Je to proto, že často příklon $\mathrm{k}$ nějaké metodě vede $\mathrm{k}$ získání principiálně nových souborů poznatků. Určitě však i proto, že verifikovatelnost takových výsledků je těžší než tam, kde se věci dají znovu změřit a výsledky porovnat, nebo tam, kde se výstupy rychle konfrontují s praktickým použitím.

Př́kladem jsou dějiny umění. Ty bezprostředně souvisí i s výzkumem v architektuře, vždyt kunsthistorie, jak jsme toto vědní odvětví zvyklí slangově nazývat, se přímo zabývá dějinami architektury jako jednoho z uměleckých druhů. Krátká historie tohoto vědního oboru zaznamenala silné a přesvědčivé školy, které vybudovaly velké uměleckohistorické teorie tak, že je principiálně postavily na nějaké ústřední metodě. Dokazuje to, že volba metody není vůbec Ihostejná vzhledem k očekávanému poznatku, který chceme daným zkoumáním získat.

Brněnský historik umění Jiří Kroupa sestavil obsáhlý přehled o celém kaleidoskopu škol a metodologických koncepcí v uměnovědě. Složitost, s jakou se přistupuje v tomto oboru k metodologickým otázkám, ilustruje jeho výrok, kde rríká, že metody badatelské práce „často bývají chápány jako určité korunování celé výuky dějin umění ... při studiu dějin umění je zapotřebí nejprve zvládnout "školu vidění a "školu vědění, tj. naučit se obrazový a historický základ dějin umění a současně osvojit si specifické badatelské remeslo - techniky výzkumné práce. Teprve nad touto vizuální a teoretickou praxí je možné sklenout určitou klenbu teoretických koncepcí a metod. "

Metoda by měla být zaměřena na cíl, strukturovaná, systematická, efektivní a přesná. Kromě toho by měla být, co se týče použití, kontrolovatelná a opakovatelná. Samozřejmě, že z hlediska doktoranda, jednotlivce s omezenými možnostmi, je důležitá i její stránka ekonomická.

Metodika je soubor konkrétních postupů a praktik, jak při určité činnosti postupovat. Při disertačních pracích je důležité rozpracovat spíše tuto rovinu postupu svého výzkumu a nespoléhat se na to, že filozofické úvahy o obecných metodách nahradí koncepčnost konkrétní výzkumné práce. Jinak řečeno, místo: „indukcí a komparací se dospělo k syntéze“ napište: „porovnáním výměry vybraných publikovaných rodinných domů v časopise Xv období 1990 až 2020 se postihly trendy".

Technika, procedura - tak se označuje konkrétní praktický postup při výzkumu. Např́klad praktický sled činností, jak zajistit průběh experimentu nebo jak měřit nějakou veličinu. Zpočátku se to může zdát jasné, ale při konkrétním úkolu, například jak měřit výměru publikovaných domů, narazíme na přízemní problémy, že ve zmíněném časopise nejsou všechny půdorysy, mají různá měř́tka a podobně.

Důležitost zabývat se ve vědě metodou vyplývá ze známého faktu, že různým způsobem se lze dostat k jinému cíli: ujasnit si metodu tedy znamená do určité míry si také ujasnit cíl zkoumání. Ale ve vědě má uvedení postupu i jiný účel. Umožníte dalším vědcům ověřit si váš výsledek. Vaši metodu mohou dále použít $k$ získání nového poznatku v podobné oblasti. $Z$ toho současně vyplývá, že vědec není povinen být při sestavování své metody originální. To je někdy nepatřičná představa architektů při disertační práci - přenášejí sem představu o originalitě, obvyklou při práci umělce. Originální však má být výsledek, metodu můžete okopírovat. Samozřejmě uved'te, odkud jste ji převzali a pokud je od dobrého autora, pomáháte tím důvěryhodnosti svého postupu a jeho výsledku.

Metody výzkumu se ještě mohou lišit podle druhu výzkumu.

Základní výzkum je takový, který je zaměřen na nalezení nějakého nového poznatku, je motivován prostě zvědavostí něco znát a nepředpokládá se nějaké bezprostřední praktické využití jeho výstupu. Výsledky základního výzkumu šiŕí vědci publikováním hlavně ve vědeckých časopisech, 
v knihách a v konferenčních příspěvcích. Jeden můj kolega, první manžel třetí manželky V. Karfíka, uváděl rád tento př́klad ze základního výzkumu: postupné poznávání toho,jak žijí a jak se rozmnožují komáři. Věc zdánlivě neužitečná. Zjistili však přitom také to, že přenášejí malárii a množí se v bažinách. $Z$ toho byl už jenom krůček $\mathrm{k}$ velice užitečnému závěru: vysušíme bažiny - potlačíme malárii.

Aplikovaný výzkum ví, co chce, ale neví, jak to udělat. ${ }^{44}$ Vědci zde mají před sebou konkrétní otázku, praktický problém a hledají způsob jeho řešení. Obyčejně jej formuluje externí organizace, která má na jeho řešení prímý zájem a také jej financuje. Někdy se hovoří o sledovatelském výzkumu, což je kategorie, která se sice považuje za celkem méněcennou, neznamená to však, že by se nevyskytovala. Je to takový typ hlavně aplikovaného výzkumu, který jen sleduje nějaké vyspělé jiné výzkumy. Určitý aspekt „sledování je př́tomen v každém výzkumu, který chce být na aktuální úrovni poznání stavu problematiky. Vzhledem $k$ tomu, že disertační práce je nejzákladnějším typem výzkumné práce, nemusí mít daleko do takového typu vědecké práce. Pojmenování „sledovatelský“ se vždy bralo jako deklasující, už se ani nepoužívá, místo něj se objevuje například honosnější reporting čili prostý sběr údajů o nějaké věci bez zvláštních závěrů.

Vyšší úrovně vědeckého poznání můžeme potom označit jako: popis (deskripce), kde se již snažíme zodpovědět na otázku co, kdy, kde a jak se stalo; vysvětlení (explanace), když už umíme dát i odpověd' na otázku, jak a jakým zpưsobem se to stalo; předvídání (predikce), která je již výsledkem zkoumání těch vědních oborů, které dokáží formulovat univerzálně platné zákony a zákonitosti a které již umí dát odpověd' na otázku, jak se bude systém chovat (za určitých podmínek). ${ }^{45}$

\subsection{LOGICKÉ METODY}

Věda používá postupy, které jsou běžné v logickém myšlení a aplikujeme je víceméně nevědomky. Dále si přiblížíme obecné postupy myšlení a uvažování, které jsou používány ve vědecké činnosti často jako samozřejmé. Není však na místě uvádět je tam, kde se očekává specifikace konkrétního postupu použitého při výzkumu tématu disertační práce. Metodolog Břetislav Fajkus připomíná, že „nejobecnejší metody jsou ve své aplikaci ve vědecké činnosti velmi slabé. Nejsilnějšími metodami, které vedou k nejlepším výsledkům, jsou dílči specifické metody. " ${ }^{46}$

Proto doporučuji více se $v$ disertaci soustředit na prostší a těsněji s vlastní tématem svázané postupy bádání, které se dají označit spíše jako metodika. Například Maroš Volovár v koncepci své disertace Dřevěný skelet ve stavební tradici horního Potisí jde hned při první větě in medias res: „Základem práce je fyzický průzkum objektů v terénu. “A pokračuje konkrétně: „Ruinosita doprovázena narušením konstrukcí nabízi badateli smutnou výhodu; objekt se sečteným osudem odkrývá vstřícněji svou stavební podstatu ... a neprekáźí mu ani menší sonda do omítky, podlahy či terénu." 47

Takže berte následující výčet jenom jako letmou informaci o lidském myšlení, vůbec ne jako návod jak popsat svou metodu.

Analýza a syntéza tvoří nejběžnější logický postup a jsou to vlastně klíčové vědecké metody. Při analýze se fakticky nebo myšlenkově rozčlení celek na části, kterými jsou prvky, vztahy mezi prvky, procesy a podobně. Jsou přiměřeně ucelené na to, aby se na nich daly zkoumat stejně uceleně jejich vlastnosti nebo jevy. Odděluje se tak podstatné od nepodstatného. Analýza může být charakteru klasifikačního (rozdělení do klasifikačních tříd), obsahového, funkčního apod. Syntéza doplňuje analýzu v dalším kroku zkoumání, když se vytvárí celek postupem zdola nahoru, skládáním původně analýzou rozčleněných částí do skloubeného celku. Oba postupy jsou však tak samozřejmé a triviální, že je zcela zbytečné je v disertaci vůbec uvádět, natož tvrdit, že je to jediná metoda, kterou použíáme.

Abstrakce a konkretizace. Výběr podstatných charakteristik a odsunutí těch, které jsou nepodstatné, se nazývá abstrakce. Vznikne tak model objektu, který nám lépe dovolí zkoumat ty vybrané jevy, které nás zajímají a při kterých si klademe výzkumné otázky. Konkretizace je opačný proces, při kterém zase vyhledáváme konkrétní objekt, který reprezentuje nějakou skupinu a vztahujeme na něj vlastnosti této skupiny. 
Indukce a dedukce je dvojice metod, která stojí za rozlišením vědy na dva základní tábory: vědy, které považují matematizaci za nevyhnutnou pracují častěji induktivně, „,humanistickým“ vědám je bližší dedukce. Indukce je tedy vytvoření závěru na základě jednotlivostí. Začíná pozorováním, ve kterém pátráme po nějakých pravidelnostech, které snad existují ve zkoumané realitě. Na základě jednotlivostí se postupně skládá obraz o nějaké pravidelnosti, zákonitosti nebo o zákonu, kterým se daný výsek skutečnosti řídí. Zde se obvykle na počátku výzkumu zformulují hypotézy, které předpokládají, jaké spojení mezi proměnnými bychom měli najít, pokud je hypotéza pravdivá. ${ }^{48}$

Vědy, které svůj předmět jen popisují, vycházejí častěji z deduktivně získávaných poznatků. Při vytváření úsudku se postupuje od obecného pravidla $\mathrm{k}$ jednotlivosti a nová myšlenka potom vyplývá z obecného pravidla. Někdy na začátku stojí axiom, tj. tvrzení, které je v daném vědním oboru přijaté jako zásadně platné a jehož pravdivost netřeba dokazovat.

A. Conan Doyle uvedl ve Studii v šarlatové Sherlocka Holmese jako uživatele dedukční metody. „Předloží mi všechny dưkazy a já je pomocí svých znalostí dějin kriminalistiky obyčejně přivedu na správnou stopu. Mezi delikty je silná príbuzenská podobnost, a pokud má člověk v prstech detaily tisíce zločinů, bylo by divné, kdyby nerozřešil tisicí první zločin. "V dalších Doylových povídkách se však dedukce vyskytuje už jen zřídka a Holmesova práce je převážně induktivní. Literárně je to pochopitelné, vždyt' skládání př́iběhu - čili indukce - založené na popisu toho, jak detektiv křižuje Londýnem $v$ prestrojení, čeká v mlze na strašidelného psa nebo balancuje nad švýcarským vodopádem, je čtenářsky mnohem efektnější než nezáživné líčení toho, že jen sedí a vynáší deduktivní závěry na Baker Street č. 221b.

Modelování, model a analogie. Model vzniká abstrakcí. Vlastně i architektonický model, neboli trojrozměrná zmenšená maketa nějakého architektonického objektu nebo jeho projektu, je př́kladem takového modelu. Má jen některé vlastnosti předlohy a od ostatních se abstrahovalo. Přitom nastává podobnost s předlohou čili některé vlastnosti jsou analogické. Například prostorový dojem, který zejména laikovi zcela chybí při čtení architektonických výkresů.

Komparace neboli srovnání vyvozuje závěry z toho, že se navzájem vedle sebe postaví dva předměty, procesy apod. a hledají se na nich shoda a odlišnost. Obvykle směřuje komparace $k$ tomu, že vyvozuje závěry právě z těch odlišností, přičemž stejné vlastnosti porovnávaných předmětů jsou jakousi výchozí základnou.

$\checkmark$ době, kdy byla Bratislava hlavním městem Slovenska jako součásti Československa, ji Dušan Franců ve své studii srovnával s podobnými hlavními městy částí států a z této komparace vyvozoval závěry. ${ }^{49}$

Při generalizaci se z existence určité vlastnosti u některých zkoumaných předmětů přisoudí tato vlastnost i všem ostatním předmětům $v$ dané skupině.

Klasifikace je prostě třídění, zařazování do různých tříd podle vybraných vlastností (z latinského classis, tj. třída).

Typologizace je blízká generalizaci a klasifikaci. Namísto formulace obecných zákonitostí anebo popisu jednotlivých případů se vytvářejí souhrnné typy, např́iklad typy budov podle funkčnědispozičních vlastností. Umožňuje to uchopit skutečnost, která nejenže je složitá, ale ještě se i aktivně při architektonické tvorbě mění.

Pojem typ se používá ve více významech a může označovat:

- skupinu funkčně a dispozičně podobných architektonických objektů (např. typ: občanské stavby, průmyslové stavby);

- nejpočetnější řešení;

- normativní př́pad, nejlepší, požadované řešení.

Architektonická typologie je sice založena na klasifikaci, která vychází z poměrně jasných funkčních kritérií, ale často se vyskytují kombinace a smíšené typy. Způsobil to odklon od striktně modernistické linie oddělování funkcí. Možná právě tyto typologické hybridy by dnes mohly být objektem podrobnějšího výzkumu, když se už odstoupilo od striktní typologizace založené na funkcionalitě. 


\subsection{EMPIRICKÉ METODY}

Na bezprostředním odrazu reality jsou založeny empirické metody. Vycházejí ze zkušenosti $v$ tom smyslu, že poznatky získává sám výzkumník. Sice osobně, ale docela nezaujatě. Jen sekundárně mezi něj a realitu vstupuje technika, např́iklad nějaký měřici přístroj. Ten však má za úkol pouze zdokonalit vnímaný obraz. Empirické metody se používají jak v přírodních, tak v exaktních vědách. Mohou být kvalitativní i kvantitativní. Klíčovými empirickými metodami jsou pozorování, měření a experiment.

Pozorování - pomocí našich smyslů získáváme poznatky. Pozorujeme objekt a na něm si vyčleňujeme předmět výzkumu, tj. to, na co se zaměřuje naše výzkumná otázka nebo hypotéza. Výsledkem pozorování je napríklad to, že doktorand našel na východním Slovensku pravděpodobně poslední dvě stavby zvláštní archaické konstrukce nebo prozkoumal dispozici a ornamentální výzdobu amerikánských domů na Zemplíně.

Často se pozorování spojuje s induktivním výzkumem, někteří ho označují jako fenomenologický, protože se zaměřuje na subjektivní vnímání a uvědomování si světa. Různé situace vidí různí pozorovatelé různě podle momentálních podmínek a vlastní zainteresovanosti. Na tom také závisejí výsledky jejich výzkumu. ${ }^{50} \mathrm{~V}$ tomto prípadě si výzkumník nevytýčí nějakou hypotézu, ale pouze si obecně zformuluje výzkumnou otázku. Etnograf se naučí jazyk kmene, sprátelí se s ním, usadí se na místě a pozoruje život, například způsob, jakým staví svá obydlí. Je to postup, který trochu připomíná Napoleonovo: „Dáme se do toho a pak se uvidí."

Měření už o zkoumaném objektu podává obraz, ve kterém jsou kvantitativní údaje a pozitivisticky orientovaní vědci jej považují za zralejší způsob bádání než kvalitativní výzkum. Výsledek pozorování už nezůstává jenom při mlhavých zjištěních, jako např. v předchozím př́kladu, ale je jednoznačně číselný. Přírodní vědy při něm používají různé technické pomůcky a škály, které pomáhají výzkumníkovi upřesnit zkoumaný obraz.

Měření se sice zdá být striktně exaktní metodou, ale měřit se nejenže dá nedůkladně nebo nepřesně, ale ve statistice se odlišuje několik možností, jak měřit veličiny:

- nominální proměnné jsou např́iklad typy: muž-žena, ano-ne;

- pořadové (ordinální) se již dají seřadit, např́iklad pořadí studentů;

- kardinální - zde víme už i vzdálenost mezi známkami ze zkoušky, a bud' ještě nemáme nulový bod, počátek, tehdy jde o intervalové proměnné, nebo je známý, a tehdy jsou to poměrové proměnné. Disertace, která zkoumá vývoj obytných ploch rodinného domu (proměnná je počet $\mathrm{m}^{2}$ ) $\vee$ čase, pracuje $s$ takovým typem proměnných.

I měření však může zůstat v poloze mlhavé, pokud nestanovíme jasné podmínky, za kterých se realizovalo. Jasné podmínky umožňují jiným výzkumníkům měření zopakovat za stejných podmínek a ověřit jeho výsledky. ${ }^{51}$

Experiment čili vědecký pokus je významná empirická metoda, při které se již cílevědomou procedurou zkoušejí dopady výzkumníky řízené přeměny nějaké veličiny. Přitom všechny ostatní vlastnosti zkoumaného předmětu jsou stabilizované, nemění se. Na rozdíl od pozorování, při kterém stojí subjekt mimo děj, zde do něj prrímo zasahuje. I zde se však sem tam objeví jakýsi hybrid mezi nezávislým pozorováním a experimentem - tzv. myšlenkový experiment. Přísně vzato to experiment není, je to jenom dohad založený na uvažování, hypotetická konstrukce, která má napomoci pochopit určitý problém. ${ }^{52}$ Za myšlenkový experiment označil například Einstein svou úvahu o tom, že neštastníci v padající výtahové kabině jsou jakoby v beztížném stavu.

Při takovém složitém systému jako je architektura se však těžko nachází izolovaný problém, který by se dal vyčlenit z reality a vyjmout z přirozeně probíhajícího děje a zkoumat skutečně experimentálně. $V$ oblasti architektury se někdy používal pojem ve významu pokusu o nějaké jiné řešení, o jiný, lepší návrh, o prolomení stereotypu zaběhnutých koncepcí. To však není experiment vědeckého charakteru. Takový byl např́iklad projekt bratislavské sídliště Dlhé diely, který se původně jmenoval EOS, což znamenalo Experimentální obytný soubor.

V souvislosti s experimentem si zvláštní pozornost zasluhuje pojem hypotéza. Při experimentální metodě je hypotéza integrální součástí prípravy a průběhu výzkumu, protože 
experiment se připravuje v intencích nějaké představy o fungování předmětu zkoumání. Hypotéza je také součástí jiného než experimentálního výzkumu, pokud má deduktivní charakter. Vycházíme-li však z postupného induktivního skládání obrazu a výzkum má spíše charakter narace (vysvětlování založené na pochopení), ustupuje smysl hypotézy do pozadí, resp. někdy zcela ztrácí smysl. Napríklad při biografii architekta čili prostém výkladu běhu jeho života a tvorby nemá formulace hypotézy nějaký podstatný smysl. Pokud se pokoušíme o její formulování, bývá často triviální a naivní.

Hypotéza tedy je předběžné tvrzení, které předpokládá nějaký vztah mezi proměnnými. Měla by být stručná, logická a jednoduchá, obvykle v podobě oznamovací věty. Nemá to být definice a nemají se v ní objevit osobní preference ani povrchní, obecně známá konstatování. Hypotéza obsahuje dvě proměnné, které vstupují do zkoumaného problému. Musí být formulovány operacionálně, to znamená, že se musí dát poznat a prakticky změřit. Často se základní hypotéza rozčleňuje na podhypotézy. Hypotézy jsou tedy již z titulu své definice vyhrazeny pro kvantitativní výzkum.

Hypoteticky tvrdit, že pestrobarevné nemocniční prostředí urychluje uzdravování, vyžaduje důkladné zpracování podhypotéz, ve kterých se navazuje na nějakou psychologickou teorii a které stanoví měřitelné proměnné. $V$ publikaci Architektonické řešení prostředí pro osoby s Parkinsonovou nemoci, ${ }^{53}$ která vycházela z disertace J. Tomandla zaměřené na architektonické úpravy vhodné pro nemocné zmíněnou chorobou, se experimentálně ověřovala hypotéza o určitém typu geometrických vzorů dlažby, které ztěžují postiženým plynulý pohyb.

\subsection{EXAKTNÍ A POPISNÍ METODY}

Pochybnosti o univerzální vhodnosti používání hypotéz nás opět přivádějí k zmíněnému rozdělení vědních oborů, a to podle toho, zda dokáží zformulovat prediktivní fungující zákony, nebo jsou zaměřeny na popisování skutečnosti bez podobné ambice.

\section{Kvantitativní a kvalitativní metody}

Výsadou vědy je přesnost a největších úspěchů dosáhla věda, která ji vyznává. S přesností je integrálně spojeno kvantitativní zjištování. Model, podle kterého je ideálem vědy matematizace jejího metodologického aparátu, mnoho vědců vyznává dodnes. Celý pozitivisticky orientovaný proud podceňuje „měkké vědy“ a jejich výzkumníky označuje za novináře nebo za měkké vědce a jejich práci za nevědeckou nebo průzkumnou a plnou osobní předpojatosti. ${ }^{54}$ Kvalitativní výzkum považují za vhodný jen v prvních fázích výzkumu, kdy o věci víme jen málo. Je to podle nich jen jakési vnořování se do přirozeně se vyskytujících událostí a má pouze anekdotický charakter. Namísto statistické průkaznosti se takový výzkum podle nich věnuje jen popisu ojedinělých případů. Kvalitativní výzkumníci například v oblasti sociologie preferují spíše analýzu slov a obrazů než čísel, dále přirozeně se vyskytující data, pozorování před experimentem, spíše induktivní výzkum (jehož výsledkem jsou hypotézy) jako deduktivní testování hypotéz a odmítají př́rodní vědy jako jediný vědecký model.

Oblast architektury je pole, na kterém se vyskytují možnosti pro aplikování kvantitativních i kvalitativních skupin metod. Při hloubkovém dílčím výzkumu se nabízejí spiše ty první, obvyklé $\checkmark$ prírodních a technických disciplínách. Při zkoumání sociálně-duchovní a zejména umělecké stránky a při celostním př́stupu k problematice architektury zase ty druhé kvalitativní - pro výzkumy popisné, narativní a interpretující.

\section{Výzkum navrhováním}

Před samotným architektonickým navrhováním se získávají poznatky o faktech souvisejících s budoucím dílem a o jeho souvislostech. Určitou míru poznávání nového vykazuje i samotná tvorba projektu a návrhu díla. $V$ celých dějinách teorií architektury počínaje Vitruviem se objevuje i poznávání, které není jen z kategorie uměleckého poznávání světa, tedy ze sféry mimovědecké. Většina z těch, kdo formulovali architektonické teorie, byli praktikující architekti, často s výjimečnými zásluhami. 
Neobyčejný rozvoj vědy, její systematická podpora a tlak na vědecký typ poznávání a získávání a šíření poznatků včetně pedagogického šíření vedl architektonickou pedagogickou obec $k$ tomu, že formulovala v hrubých rysech koncept výzkumu navrhováním. Je to pokus dokázat, že je to sice takový výzkum, který nezačíná formulací výzkumné otázky, ale z architektonického návrhu zobecňuje nový poznatek, který návrh přesahuje a směřuje k zobecnění. ${ }^{55}$ Uznává se zde sice, že výsledky je potřeba vyjádřit jazykem, ale připomíná také význam mimojazykových prostředků (skica, kresba). $\checkmark$ této souvislosti se někdy mluví také o akčním výzkumu.

Právě disertační práce, které mají často charakter testování nových cest, mohou iniciovat rozvoj takového výzkumu. Jejich autoři mají dobré předpoklady bez předsudků spojit znalosti o procesu architektonického navrhování s bádavostí zaměřenou na nové poznání na hranici dvou světů: inženýrsko-uměleckého a vědecko-poznávacího. Například v souvislosti se sutěží Solar Decatlon zaměřenou na postavení energeticky soběstačného domu se objevila na FA ČVUT podobná disertace.

\section{Specifické metody}

$\checkmark$ předchozích odstavcích jsme probrali několik druhů rozlišování metod ve vědě. Nejsou to navzájem se vylučující způsoby, naopak se proplétají. Př́kladem mohou být metody, které nabízí např́iklad statistika. Určitě by pomohlo výzkumu v oblasti architektury, kdyby v povědomí autorů disertací byly alespoň obecné informace o nejen tom, co je aritmetický prüměr, ale také o tom, že medián je střední hodnota, modus je nejčastější hodnota nebo alespoň základní povědomí o složitějších termínech jako je rozptyl, korelace, průměrná nebo směrodatná odchylka či vícerozměrná analýza apod.

\subsection{VÝBĚR METODY}

Architektura, pokud o ní mluvíme ve významu vědní disciplíny, se nemůže pyšnit svou podobně jasně vymezenou metodou. Ale výzkum zde má k dispozici celou baterii metod vypracovaných jinými disciplínami a může si je přizpůsobit svým speciálním požadavkům. Při jedné jediné vědecké práci, jakou je i disertace, pravda, hrozí nebezpečí kombinace více metod. Problém může zůstat nevyřešený a hrozí, že se přejde od jedné metodě k druhé, aniž se důkladně využijí. Je to podobné jako při nedostatečném zúžení výzkumného tématu. Nic ale nestojí v cestě probrat, přizpůsobit a důkladně aplikovat jednu dvě metody. Například nějakou historiografickou metodu pro přibližení minulosti zkoumaného problému a na hlubší ponor do problematiky použít nějakou další dobře zvolenou a prověřenou metodu, třeba zkoumat metodou space syntax dispozici těch architektonických typů, kterými se má disertace zabývat, anebo použít metodu mentálního obrazu na poznávání toho, jak vnímají obyvatelé své architektonické prostředí.

\section{Heuristika}

V první kapitole jsme se dostali až k pochybování o vědeckých metodách, které do seriózního filozofického diskurzu vnesl P. Feyerabend. Ne všechny vědecké metody jsou tak jasně vymezitelné, jak by to mohlo vypadat podle předchozích řádků. Při pozorování a experimentování se vždy může objevit něco neočekávaného, náhlého či kreativního. Vědci se často setkávají s novými situacemi, se shodami zvláštních okolností, s plodnými myšlenkovými zkraty nebo se štastnými náhodami. Horace Walpole, jinak i architekt-amatér a autor prvního romantického anglického objektu, použil v jednom listu pojmenování serependitivita pro označení situace, kdy št́astně najdete něco, co jste vůbec nehledali. Pojmenování vytvořil podle pohádky o třech princích ze Serendipu (starší pojmenování Srí Lanky), kteří náhodně a s důvtipem objevovali věci, které nehledali.

Podle Archimédova výkřiku Heuréka! (Objevil jsem), kdy prý při koupání ve vaně přišel na svůj slavný zákon, se nazývá heuristikou i postup vynalézání, který obsahuje v sobě náhodné prvky nebo používá řešení př́pad od případu, čili často postup pokus a omyl. Je to pokusné řešení problému, přičemž předem neznáme postup ani nějakou zřetelnou metodu, jak k věci přistoupit. 


\section{Zkreslení při poznávání}

Při používání zmíněných metod uvažování a vědeckého zkoumání se však může stát, že podlehnete některým zkreslením. Zejména ta, které jsou lidem psychologicky vlastní, mohou vědecké poznávání poznamenat. Například při generalizaci, jinak řečeno stereotypu, můžete nesprávně usoudit na vlastnosti věci podle její př́ślušnosti k nějaké skupině či tř́iě. Někdo např́íklad může takovou chybnou stereotypizací považovat Behrensovo krematorium v Hagenu za kostel, protože má vysokou věž. Je to však komín. Na internetu byl jednou překvapený komentář k budově pražského archivu na Chodově, kde si pisatel myslel, že je to akvapark - budova má totiž dole na průčelí veselé barevné linky a nahoře modré lesklé prosklení. Často se k stereotypizaci uchylujeme při usuzování o jedinci podle jeho př́slušnosti k etniku nebo národu, protože jeho vlastnosti na první pohled nejsou viditelné a často potřebujeme udělat rychlou identifikaci neznámého jako př́tele či nepřítele. $\checkmark$ tomto př́padě je však zřejmé, že se dostáváme na hranici, odkud je už jenom krůček k xenofobii.

Stereotypizace je však vlastně v základech vědecké metody klasifikace, tj. zařazení předmětů a jevů do širší skupiny odlišné od skupiny jiné. Nakonec samotné definování a definice jsou určitým způsobem tohoto zatřídění a v pozadí je stereotypizování.

Informace, které nás nezajímají, jsou nám vzdálené či nechtěné, více či méně odfiltrujeme nebo zcela odblokujeme tzv. výběrovým vnímáním. Laici se například jen zřídka ohližejí na budovy jako na celek a znají je převážně jen do úrovně parteru. Výše zrak zvedají jen zřídka. Je to proces, který má význam při koncentraci na podstatné. Může se však stát, že při vědeckém poznávání způsobí ztrátu toho, co je podstatné, ale ne očividné.

Pod vlivem dojmu z úspěšného výsledku se méně učíme na problémech, které se vyskytly při jeho realizaci. $V$ anglosaském světě je známá Scottova tragédie při dobývání jižního pólu. Často se za příčinu jeho neúspěchu považovalo použití mongolských poníkủ (úspěšný Amudsen použil psy). Poníky však měl už dva roky předtím polárník Ernst Shackleton a jeho výpravu hodnotili jako velmi úspěšnou. Kladný výsledek zde zastínil negativa, ačkoli o ponících se již tehdy pochybovalo. Analýza chyb jiných postupů, ačkoli úspěšných, má také v aplikaci vědecké metody velký význam.

\subsection{DOBRÉ RADY NA ZÁVĚR - ZATŘETÍ}

Namísto obecných metod mluvte konkrétně o vaší metodice.

Nebojte se experimentu - dá vám argumenty, o kterých víte jen vy.

Namísto triviální hypotézy raději zformulujte hluboké výzkumné otázky.

Metodu nevymýšlejte, ale okopírujte.

Kvantifikace nespasí, ale pomůže.

Pokud má být výsledkem práce metodika, jste si jistý, že ji někdo použije?

Vyvarujte se chyb stereotypizace a výběru.

Zkuste poznatek z research by design ríct jazykem vědy. 


\section{CO VĚDí JINÍ}

\subsection{PRVOTNÍ ZÍSKÁVÁNÍ POZNATKŮ}

První stádium výzkumu je vědět, co vědí ostatní.

V. Zamarovský

\section{Současný stav poznání}

Z původně formulovaného názvu disertace sice již vyplývá nějaká představa o jejích podrobnostech a o oblastech, kterými se bude zabývat, nejdřive se však ponořte do zjištování, co o dané věci vědí jiní. Je možné, že některá témata jsou již v prvotním stádiu tak jasná, že se z nich dají vyvodit precizní výzkumné otázky, respektive hypotézy. Obvykle však v oblasti architektury trpí původně stanovená témata větší šířkou záběru a většími očekáváními od závěrečných odpovědí. $\checkmark$ takovém prípadě je velmi důležité nejen se důkladně seznámit se současným stavem poznání věcí podobných a blízkých, ale současně je třeba pracovat na upřesnění otázek, které se ve výzkumu kladou a které dokáže autor disertace pravděpodobně perspektivně odpovědět. Je to fáze, v níž se provádí inventura dosavadního vědeckého poznání a hledají se v něm bílá místa.

Tato část práce na disertaci vyústí do standardně požadované součásti závěrečného textu, která nese obvykle název Současný stav problematiky a přehled literatury. Tuto kapitolu je možné $v$ hrubých rysech napsat vlastně jako první, protože tento informační výzkum je na začátku prací na disertaci.

Klasický postup prvotního sběru informací o předmětu výzkumu by se dal popsat takto: nejdřive sáhnete po informacích encyklopedického charakteru a objasníte si okruh vašeho zájmu $\checkmark$ nejhrubších rysech. Uvědomte si přitom, že encyklopedie ani Wikipedie není plnohodnotný vědecký zdroj důkazů, ale v první fázi jsou k nezaplacení. Kontrolujte získané informace porovnáváním s jinými podobnými zdroji. Kdosi řekl, že web má jednu velkou výhodu - je na něm obrovské množství informací - a jednu velkou nevýhodu - je na něm obrovské množství informací. Umberto Eco vzpomínal, že jednou na Wikipedii poopravil údaj týkající se jeho ženy, ale druhý den tam byl zase ten původní.

Encyklopedie ne vždy uvádějí autory jednotlivých hesel. Takže ted' už jen já sám vím, že jsem měl tu čest sestavit heslo Architektura do Encyclopaedia Beliana. $V$ dobách, kdy byla k dispozici pouze knižní linie získávání takových poznatků, bylo třeba se dostat dál k monografiím a časopisům v daném oboru. Odkazy v knihách nebo v časopiseckých článcích pak postupně přivedly $\mathrm{k}$ autorům, kteří se nejvíce približili ke zkoumanému problému.

Neobstojí častý doktorský argument, že na světě neexistuje nikdo, kdo by se už danou věcí zabýval. Je na něm odstín pravdy pouze $v$ tom, že určitě musíte přinést nějaký zcela nový poznatek pokud bychom o něm už věděli, byl by váš výzkum přece zbytečný. Ale zas naopak - o potřebě takového poznatku přece svědčí to, že je tím bílým místem, které chybí, tedy víme o něm přinejmenším to, že chybí.

Postupným přibližováním se $\mathrm{k}$ poznání, které je v dané době aktuální, se dostanete $\mathrm{k}$ jakési kruhovosti: zjištujujete, že velká většina textů se opírá o některé uznávané autority, opakovaně jich citují a staví na jejich myšlenkách. $V$ tomto okamžiku se již dostanete do stadia, kdy jste informováni o hlavní linii současného stavu vědeckého poznání.

Přirozeně toto poznání nemusí být dokonalé, v nějaké cizojazyčné marginální knize může být zmínka o pokusech nějakého brněnského řeholníka a vy ji nezaregistrujete. Tak to prý bylo s Darwinem, který měl v knihovně německou knihu, jejíž autor vzpomínal, byt' s nepochopením, Mendelovy pokusy. Darwin však tu knihu určitě nečetl, neměl ji totiž na daném místě ani rozříznutou. Tak se mu nezdařilo správně vysvětlit problém smíšené dědičnosti.

$\checkmark$ každém případě však Ize sestavit první přehled a vlastně první kapitolu vaší disertace. Ta dozná sice později několika zdokonalení, když objevíte své „Mendely“, ale už nyní na jejím základě můžete upřesnit své výzkumné otázky a cíle. 
Dobře zpracovaný přehled literatury nejenže dokáže, že váš problém stojí za to řešit, ale díky němu si také umíte položit jasnější otázky. Chybou je, když se pod přehledem literatury rozumí pouze její mechanický seznam. Nezbytné je i věcně uvést, co je charakteristické pro danou knihu nebo článek a upozornit na to, $v$ čem je to důležité pro zaměření a výsledky vašeho výzkumu.

\section{Moderní informační zdroje}

Oproti dávným časům, kdy základními zdroji informací byla tištěná média zvaná knihy a časopisy, se tyto zdroje dnes rozšírily díky digitalizaci o média elektronická. Sofistikované knihovní služby vám již nabízejí přístup $\mathrm{k}$ různým typům databází, rozšiřil se otevřený přístup $\mathrm{k}$ vědeckým informacím, nebot panuje přesvědčení, že výsledky výzkumu podporovaného z veřejných zdrojů by měly být i volně veřejně př́istupné. Rozrůstají se repozitáře a databázové zdroje digitalizovaných diplomových a disertačních prací. $V$ některých se dostanete volně $\mathrm{k}$ celému textu, některé nabízejí jen ukázky prvních stran nebo pouze abstrakt a plný text si můžete za poplatek objednat. Hledat v nich Ize podle autora, slova v názvu, podle klíčových slov apod. Samostatné databáze mají vydavatelé, různé vědní obory i projekty podporované granty Evropské unie.

Hlavními zdroji pro vás budou na prvním místě dobré časopisy a dobré knihy, klasické i elektronické, ale informace zkuste hledat i v tzv. šedé literatuře, tj. v nekonvenčních dokumentech, které nevznikají běžnými vydavatelskými postupy. Patří sem již zmíněné kvalifikační práce (čili i disertace), výroční, výzkumné a nálezové zprávy, firemní literatura, pracovní a studijní materiály, postery, samizdat, prezentace, doprovodné zprávy $\mathrm{k}$ architektonickým projektům a podobně. Zde si však třeba být vědom toho, že pracujete s jinými údaji, než jsou vědecky prověřené a recenzované informace $v$ časopisech a knihách renomovaných vydavatelství.

Zorientovat se v obrovské záplavě těchto informačních zdrojů je jistě náročné, ale smysl je stále týž: vedle toho, že získáte sem tam nějakou výbornou ideu, nejednou i z marginálního zdroje, se především dopracujete $k$ opakovaně zmiňovaným zdrojům, autorům (a i institucím), odkud pocházejí ty nejpodstatnější informace $k$ studované věci.

Samozřejmě bud'te připraveni na to, že tato mohutná práce, kterou pro nás provádí dnešní knihovnická a informační služba, může někdy vést k nepřesnostem, které odhalí pouze odborník zahloubaný do tajů dané oblasti. Jednou se mi stalo, že našemu oddělení architektury nabídla knihovna soubor bibliografických záznamů, které by nás mohly zajímat. A protože prý architektura se rovná životní prostředí, byl to svébytný mix: do životního prostředí patří i myslivost, ocitl se tam i titul: Lov srnčí zvěre kulovnicí.

\subsection{EXCERPCE}

Manfred Spitzer napsal knihu Digitální demence ${ }^{56}, \mathrm{v}$ niž upozorňuje na některé pochybné defektní důsledky digitalizace a zastává se klasických způsobů, např́íklad ručního psaní. Ve všeobecném nadšení nad tím, jaké nesmírné možnosti poskytuje digitalizace, se i část slavné knihy Umberta Eca o psaní disertační práce dočkala v úvodu k českému překladu blahosklonného úsměvu. Je to část o tom, jak si poznamenávat výpisky z knih. Eco doporučuje psát pracovní obsah tužkou (sic!) a pak to při opravování a změnách gumovat. Právě to jsem před chvílí udělal i já s rozpisem kapitol této publikace. Ještě na papíre vidím stopy po předchozím rozvržení. Kdybych to měl $\checkmark$ počítači, stopy by nebyly žádné a ten původní starý soubor by sice byl kdesi uložen. Ale kde? Můžete říct, že je to hodně konzervativní. Ale Eco přece psal v éře psacích strojů, proč pak asi hovoří o tužce a gumování?

Už dvakrát jsem zkusil převést své poznámky a celou klasickou lístkovou kartotéku do digitální podoby. Láká mě to fantasticky lehké hledání, třídění, napojení na podobné externí databáze apod. Vždy, když se dozvídám o bujení takovýchto postupů a o tom, jak to univerzitní knihovny nabízejí na různých kurzech, sleduji to se závistí. Ale přece jen, nemají půlstoletí staré Ecovy návody něco do sebe? Jakési to přirozené první přibližování se k vědecké práci podobně, jako se i dnes žáci v první třídě stále ještě učí psát rukou a kreslit tužkou? Když vidím ve své kartotéce zažloutlé kartičky, které jsou z počátků mé vědecké práce, nebo rǔžové lístky, které jsem jediné dostal na služební cestě 
v papírnictví v Kotvě a na kterých mám poznámky z článku P. Halíka o sorele - to jsou příznaky, které digitálnímu záznamu chybí. Ani výborný systém oken zvaný Windows nenahradí rozložení klasických papírových kartiček po celém stole tehdy, když je třeba skládat celek rozsáhlého textu. Kolik souborů, které vznikly př́ležitostně jako drobné nápady, jsem porůznu pozastrkoval, překopíroval do zálohy a pak někde odložil pod záhadným názvem tak, že je objevuji už jen náhodou a omylem? Kladu si otázku, zda je zase až taková skvělá výhoda v tom, že se dá pracovat na nějakém externím úložišti $z$ více počítačů nebo mobilů. Je to plnohodnotná náhrada koncentrované práce na jednom, na to určeném místě? Proto jsem se po dvou vážně míněných, ale nedokončených pokusech vrátil ke kartotéce, tak jak ji popsal Eco a jak se ještě, byt jen v podobě historické rarity, vyskytuje ve vedlejších místnostech knihoven.

\section{Výpisky, databáze, kartotéky}

Současně s postupným vyhledáváním pramenů o svém tématu si o nich musíte zaznamenávat základní identifikační údaje a vybírat z nich to, co potřebujete $\mathrm{k}$ jeho řešení. Zde se začíná úmorná a zčásti jen mechanická práce, jejiž výsledky však oceníte $v$ nejtěžších chvilích při ixté závěrečné úpravě finálního textu. Pod dojmem principiální důležitosti prvního přibližování se $k$ tématu má totiž člověk dojem, že na drobnostech ještě nezáleží. Pokud však potom v posledních hodinách práce zjistíte, že nemáte detailní údaje o citované knize, následuje únavná a trpká odbočka. Dnes už na webu sice rychle najdu ISBN knih, jejichž tituly jsem si poznamenal ještě v době, kdy bylo ISBN v počátcích, ale některá dodatečná zjištování vůbec nejsou tak jednoduchá. Proto nezapomeňte: i první poznámky si pište důkladně a čitelně. Jistěže se k seznamu vhodných pramenů a titulů dostáváte postupně a někdy si nejprve opišete pouze předběžně celý seznam literatury, kterou zmiňuje nějaký hodnotný článek. Teprve pak se dostáváte ke konkrétním titulům. Případně získáte novější vydání nebo jiný příspěvek téhož autora. I to však doplňujte do své databáze či kartotéky. Přičemž drobná specifika na ručně psané kartičce naznačuji i kontext doplňujícího záznamu. Do počítače se však musí taková informace explicitně vložit a dejte pozor, když přepisujete původní údaje - žádné stopy po těch původních tam nezůstanou a nežrídka by stálo za to o nich vědět.

Bibliografická databáze-kartotéka je základní pro práci se souvisejícími zdroji poznatků a její důkladné zpracování se vyplatí při sestavování závěrečného seznamu literatury. Klasická kartotéka má své velké výhody, ale hrozí při ní jisté prostorové omezení: některé prameny excerpujete podrobněji a klasický lístek běžné velikosti vám už nemusí stačit. Je na úvaze disertanta, zda pro něj není vhodnější poznamenávat si informace do svázaného sešitu nebo si je ukládat do počítače, kde toto prostorové omezení nehrozí. Každý z těchto způsobů má své výhody. S kartičkami lze zacházet ve větším množství, lze je přeskupovat a poskytují dobrý přehled rozložené na stole. Ti, kteří se umí dobře orientovat podle času vzniku prrírůstků, mohou sáhnout k zapisování do svázaného sešitu. Nedovoluje to už sice přiřazovat pozdější poznámky ke knize už jednou excerpované, přestože i zde se dá najít řešení. Spisovatel Ondřej Neff vzpomínal, jak jeho otec pracoval na doplňování svého Filosofického slovníku pro samouky: k původní verzi doplňoval novější poznámky jako úzké listy papíru slepené do šlahounů dlouhých někdy až dva metry.

Pro ty, kteří tento způsob považují za zcela překonaný, je zde samozřejmě možnost ukládat excerpce do počítače. $Z$ nich se pak dá s výhodou přenášet požadovaný text a citát do závěrečné podoby disertace, zatímco u předchozích dvou způsobů to vyžaduje otrocké ruční propisování.

Dobře vedená bibliografická databáze ve všech třech variantách ušetř́ jiné únavné psaní těch otravných údajů, například ISBN na všechny jiné záznamy. Stačí stručný odkaz typu: AUTOR, rok.

Kartotéka na kartotéčních lístcích musí mít však jednotný princip řazení, zatímco při elektronické databázi je problém řazení irelevantní. Jelikož jde o autorská díla, předpokládáme, že to bude autorský katalog. Během prací na disertaci se sice mohou jednotlivé lístky ocitnout zařazené jinde, např́klad pod jednotlivými uvažovanými kapitolami, ale základem bibliografické databázekartotéky je pochopitelně autorský katalog.

Různé typy disertací si však mohou vyžádat jiné druhy databází. Při architektonickém výzkumu se hlavně nabízí nějaká věcná, předmětová či objektová databáze. Důležité je rozhodnutí o způsobu řazení záznamů. Mně se dlouhodobě osvědčila rozsáhlá objektová databáze architektonických děl, 
v niž snadno najdu detailní údaje například o roku vzniku projektu, spoluautorovi a podobně. Taková databáze přiměřeného rozsahu a obsahového záběru se velmi dobře hodí při induktivní práci s rozsáhlejším souborem architektonických objektů. Její součástí mohou být nejen číselné a textové informace, ale i fotografická a výkresová dokumentace.

I pro práci typu, která se při architektonickém výzkumu často vyskytuje, a to při aplikaci poznatků z nějakých jinde realizovaných staveb, má smysl důkladná informační databáze o ekvivalentních realizacích v cizině. Součástí disertace $O$. Císlera například byla analýza akustiky vybraných koncertních sálů v Evropě, která sloužila jako jeden z podnětů pro architektonický návrh nového koncertního sálu pro Prahu. Přestože šlo o výrazně autorsky individuální návrh, při kterém nebylo možno hovořit o nějakém mechanicky statistickém syntetizování získaných poznatků, přece jen sloužil k uvědomění si například dvou možných linií, které se rovnocenně ve zkoumaných návrzích vyskytovaly: koncertní sín jako krabice nebo jako vinice (shoebox, resp. vineyard).

Kromě těchto informačních databází však stojí za zvážení taková, kde bychom měli po ruce a systematicky uspořádány vlastní nápady, poznámky, podněty, úvahy a myšlenky. Umožňuje pracovat na vyšší úrovni než pouze na věcně enumerativní, $k$ čemuž mohou vést dosud zmíněné databáze. Opět se mi však zdá v př́padě takové databáze, že její uložení do počítače ji poškozuje a skrývá. Umím si představit, že s rozloženými kartičkami, na kterých by takové záznamy byly, se dá mnohem lépe a s přehledem o velkém celku (který závisí na takové trivialitě, jako jak velký stůl máme) pracovat na souhrnném závěrečném textu.

Při finálním sestavování textu, o kterém bude řeč v sedmé kapitole, totiž právě z těchto kartiček můžete složit skupiny, které vytvoří kostru kapitol závěrečné disertace. Takové kartičky mám i já právě seřazeny do skupin, leží přede mnou rozloženy na stole a vím, že je ještě nejednou budu přeskupovat a přemístovat. Stále je to však přehlednější než to hledání souborů kdesi v počítači, při kterém z nich vidím jen jejich stručné a někdy záhadné názvy. Uznávám však, že to může být způsobeno mými osobními náklonnostmi a zvykem a nechávám na vás, jakou cestou se vydáte.

Teprve při závěrečném psaní zjištúuji, jak moc mi vadí, když jsem se spolehl na to, že danou knihu budu mít po ruce a nemusím si z ní vypisovat poznámky. Vzpomínám si na jednu dávnou trpkou zkušenost, když jsem potřeboval uvést jméno autora zbouraného mad'arského veslařského klubu $\checkmark$ Bratislavě. Mluvil jsem o něm jen úplně okrajově, zabýval jsem se totiž vedlejším slovenským a německým klubem. Za nic na světě jsem si na to jméno nemohl vzpomenout. Věděl jsem však, že ho najdu v Szőnyiho knize, kterou jsem měl po ruce. A tak jsem ji nonšalantně otevřel a začal listovat, více méně od začátku více méně po konec. Nic. Tak jsem šel opačným směrem. Zase nic. Bylo jasné, že to musím projít důkladně, a tak jsem začal znovu od začátku. No a milý autor jménem Yeblinger byl skoro zcela na konci, kam jsem předtím při povrchním listování nezašel. Pưl hodiny jsem hledal jedno jediné jméno. Od té doby se však časy změnily - zkusil jsem si ted' vygooglit „bratislava madarsky veslarsky klub architekt" a hned na prvním odkazu stojí: Jeblinger. Ouha, měl bych si to ověřit u Szőnyiho, zda si dobře pamatuji ten ypsilon na začátku. Szőnyi je spolehlivější než vlastivědná stránka na webu.

Podobné složitosti spojené někdy s nejposlednějším detailem čekají na člověka tehdy, kdy nemá důkladněji zpracované původní poznámky.

\section{Archivování}

S moderními médii je spojeno ještě jedno dilema, které mi vyvstane před očima, když jdu dolů do katedrového archivu a vidím tam hmatatelné artefakty, které nashromáždili naši předchůdci. Naposledy jsem tam našel otrhanou, ale autentickou dobovou fotografii Krejcarova pavilonu ČSR v Pařiži i s kusem Eifelovky na kraji. Je tam určitě hodně šmejdů, ale sem tam se tam najde i nějaký poklad. Je tam fyzicky, zatímco stopy po naší digitální činnosti jsou možná někde v análech Googlu, ale kdo je dokáže najít a dokdy tam budou? Proto i doktorandi mohou těžko použít původní materiál z průzkumů, který jsme my shromáždili - jsou kdesi ve virtuálním neurčitě.

\subsection{ZDRAVÝ ROZUM A KRITICKÉ MYŠLENÍ}


Dnešní moderní prostředky a nebývale snadný př́stup k informacím mají nevýhodu v tom, že se hůře rozlišuje pravdivost informací. Natož když jsme zatížení stereotypy, o kterých nám dává zprávu moderní psychologie a které jsou přirozenou součástí našeho rychlého a jakoby automatického rozhodování. Má smysl připomenout si některé z těch poznávacích omylů, které mohou při prvotním získávání informací vést k chybným závěrům.

Jako takzvaný zdravý rozum je zvykem označovat prosté a přímočaré uvažování, které se dokáže vyhnout zejména zbytečným složitostem nebo deformacím, které zpưsobuje stereotyp či konvence. „Zdravý rozum“ má však své limity, je úspěšný při jednoduchém rychlém rozhodování, ale často selže, když se postaví vůči komplikovanějšímu poznání, typickému pro vědu. Přebírání informací $s$ apriorní důvěrou $v$ jejich pravdivost nám totiž běžný život často usnadňuje a kdybychom se na ně nespolehli, stal by se velmi komplikovaným.

Připomeňme si některá zkreslení, která mohou proniknout i do vědecké práce při informačním výzkumu stavu současného poznání. ${ }^{57}$ Při poznávání máme přirozený sklon více důvěřovat tomu, co potvrzuje náš názor, než tomu, co je s ním v rozporu. Nazývá se to potvrzující (konfirmační) zkreslení. Přitom náš názor může být ve shodě s nějakým povrchním aspektem a nevšimneme si skrytější souvislost. Psycholog P. C. Wason to předvedl tak, že ukázal studentům trojici čísel 2, 4, 6 s tím, aby uhodli tajné pravidlo, podle kterého jsou číla zvolena. Na pomoc jim pak ukázal další trojice: $10,12,14$, nebo $22,24,26$. Účastníci testu měli za úkol zjistit pravidlo uváděním jiných trojic. Zkusili $6,8,10$, nebo 32, 34, 36. Testující odpovídá, že ano, trojice pravidlu vyhovují a účastníci se tak utvrzovali v domnění, že pravidlo odhalili. Ale testující nesouhlasil a predložil jim trojici 3, 5, 555, která, jak uvedl, též vyhovuje pravidlu, taktéž jako řada 1, 2, 3. Tehdy však účastníci pochopili, že se dali při prvních trojicích svést původně jim jakoby předkládanou představou. Postupně si přestali tuto domněnku potvrzovat a začali zjištovat, čím by ji nahradili. Nakonec se ukázalo, že pravidlo bylo: jakákoliv tři vzestupná číla. Tedy ne sudá a vzestupná s intervalem dva, jak se nejprve zdálo.

Vyhnout se konfirmačnímu zkreslení je velmi důležité při vědecké práci, protože to může už při formulování základního výzkumného problému vést $\mathrm{k}$ stereotypnímu dokazování chybného prvotního názoru na danou věc. Nejednou se to skutečně stává, vědec se totiž v evoluční fázi vědy, jak vystihl T. Kuhn, obvykle chová konformně, má tendenci potvrzovat nastolené paradigma, respektovat a používat ustálené a uznané metody a podobně. $V$ určitých typech disertací se to vyskytuje pravidelně. Např́klad práce na témata, která jsem nazval v druhé kapitole osvětovými, usilují rozšiřovat poznatky tom, jak $v$ architektuře něco správně řešit podle jinak v okruhu vědy již známých principů, namísto toho, aby dávaly originální novou odpověd' na problém dosud nevyřešený.

Stádový efekt je všeobecně známý jev, který je založen na tom, že máme sklon automaticky přijmout to, co už přijali jiní v naší blízkosti. Čím více lidí se s věcí ztotožnilo, tím větší je pravděpodobnost, že se s ní ztotožní i jiní. Také tento jev je ve své podstatě přirozený a často užitečný. Koordinovaný let hejna ptáků je důsledkem takové stádovosti. Distanc v pojmenování „stádní“ je založen na poznání, že u lidí nejednou stádovost vede ke sledování nějakého škodlivého nebo pomýleného trendu.

Registrování iluzorních shluků je založeno na představě, že prííadné větší seskupení náhodných událostí ve skutečnosti náhodné není. Když jsem dříve přednášel většímu počtu doktorandů, na důkaz špatného odhadu některých statisticky dobře dokazatelných jevů jsem se vsadil s účastníky o to, že se mezi nimi najde dvojice, která má stejné datum (den a měsíc) narození. Člověk má dojem, že v roce, který má 365 , tedy dost, dní, najít dvě stejná data je velmi málo pravděpodobné. Když je však účastníků sázky více než 22, je tato pravděpodobnost vyšší než 50 procent. Je to proto, že jde o kombinaci každého s ostatními dvanácti a takových je už poměrně hodně. ${ }^{58}$ Podobně při hodu mincí máte dojem, že by se vlastně měl stř́ídat rub a líc, ale ve skutečnosti dochází k shluku stejných výsledků častěji než k takovému střídání. Odlišení náhodného clusteru od takového, za kterým stojí nějaká príčina, je i při vědecké analýze velmi důležité.

Upřednostňování dostupného je tendence přikládat větší význam bližším, bezprostřednějším a dostupnějším údajům. „Kouření sice škodí zdraví, ale strýc kouřil a dožil se 80 let,“ je príikladem toho, že dokázané, ale vzdálené informace o škodlivosti kouření se odsouvají a upřednostňují se ty, 
které jsou blíže. Ty jsou opakovaně vnímány, a to podporuje jejich preferenci. Jevům z bezprostřednějšího okolí přikládáme prostě větší váhu, než jaká by jim ve skutečnosti príslušela.

Kotva a přizpůsobení. Tento jev se s překvapivě významným zkreslením objevuje tehdy, kdy se máme rozhodnout v nejisté situaci a objeví se možnost navázání na nějaký údaj, na „kotvu“ čili pomocný či předběžný údaj, ke kterému můžeme naše odhady vztáhnout. Psychologové Kahneman a Tversky napřiklad uložili studentům za pět sekund rychle vypočítat, tj. vlastně odhadnout, součin osmi čísel $(8,7,6,5,4,3,2,1)$. Pět sekund je př́liš málo, obvykle člověk vynásobí prvních několik čísel a ze součinu si vytvoři „,kotvu“ a na základě ní odhadne výsledek. Obyčejně to udělá hluboko pod skutečný součin, který je 40 320. Vytváření takové kotvy potvrdila úloha, kterou dali druhé skupině: změnili jen pořadí a požadovali součin čísel $1,2,3,4,5,6,7$, 8. Tato skupina si kotvu postavila níže, protože ji odvozovala z nižšího součinu prvních čísel. První skupina uvedla výsledek 2250 , druhé pouze 512. Zmínění psychologové (přičemž Kahneman později získal Nobelovu cenu za ekonomickou teorii, která zohledňuje reálné, ne ideálně racionální chování lidí) zjistili, že tato kotva může být dokonce zcela bez vztahu ke skutečnému výsledku. Kotvou je např́klad i škrtnutá cena na cenovce se zlevněnou cenou - ovlivňuje nás, i když tušíme, že původní cena nemusí být pravdivá.

To byl výběr některých zkreslení, kterým při poznávání podléháme. Jsou to zkreslení, která nejednou usnadňují běžný život a orientaci v něm. Ale tak, jak se nemusí vyplatit v kritických situacích, hrozí zásadní deformací i při kritickém vědeckém myšlení.

\subsection{DOBRÉ RADY NA ZÁVĚR - POČTVRTÉ}

Zjistěte, co všechno už vědí jiní.

Vytvořte si své vlastní databáze nebo kartotéky.

Začněte sice u encyklopedie, přinejhorším u Wikipedie, ale pokročte k vědecky hodnotným zdrojům.

Propracujte se ke klíčovým (nejcitovanějším) autorům a sledujte jejich publikace.

Vyberte si to nejlepší, co vám nabízí vaše knihovna.

Ručně psané záznamy dělejte důkladně a čitelně, $v$ digitálních vyznačujte opravy a doplňky.

Zdravý rozum používejte s rozumem.

Vyhněte se kognitivním zkreslením. 


\section{CITOVÁNÍ}

Otázka jak citovat je často ústředním tématem příruček tohoto typu. Čím důkladněji se však odborníci touto problematikou zabývají, tím větší je počet různých předpisư, které se $k$ věci vyjadřuji, ${ }^{59}$ ačkoliv zde platí jedna z mála státních (a evropských) norem - ISO 690. Problém je v tom, že stále zůstává jako němý svědek doby masa publikací, které se řídí předchozími normami a řada knihoven, jejichž katalogy jsou zapsány podle nich. Kromě toho si dobré časopisy ustanovily své specifické, vždy trochu odlišné způsoby uvádění bibliografických citací a chvályhodně houževnatě se jich drží. ${ }^{60}$

Součástí správného zacházení s duševním majetkem jiných, ke kterému si také řekneme pár slov v této kapitole, je však i v principu správné citování. Ačkoliv zde mluvím o nejmenších možných, přímo atomických složkách textu, jako jsou tečky, čárky nebo dvojtečky, podstatných je několik principů, které se pokusím ukázat na pár hlavních příkladech a nezabřednout prítom př́liš mezi ony tečky, čárky a dvojtečky.

\subsection{PRAVIDLA (ZÁSADY) CITOVÁNÍ}

Citováním prokazujete, na jakých dosavadních myšlenkách a poznáních stavíte svůj výzkum, dokazujete svou úroveň a umožňujete ověrit správnost citace v původním zdroji nebo najít v něm inspiraci. Hlavními zásadami citování jsou:

Citujte korektně a správně proto, abyste jasně označili, kdo je autorem myšlenky nebo díla, které zmiňujete, abyste si prostě tu myšlenku nebo dílo neoprávněně nepřisvojili a aby nevznikl ani náznak dojmu, že vy jste autorem.

Citujte kompletně proto, aby si čtenář mohl podle našich údajů najít původní zdroj na to, aby si bud' ověřil správnost vaší citace, nebo aby mohl sledovat a stavět dále na myšlenkách, které $\checkmark$ citovaném díle najde. A zde je pár dalších pravidel: ${ }^{61}$

1 / Cituite v přiměřeném rozsahu. Více textu citovaného než vlastního je vysloveně nepř́ípustné. Se svou habilitační prací beznadějně neuspěl jeden z našich kolegů, když z těžko vysvětlitelných důvodů měl v práci úplnou převahu citovaných textů, zatímco jeho vlastní text byl jen jejich velice krátkým doplňkem.

2 / Citujte absolutně věrně, případné vsuvky (např. opravu chyby) a vypuštění označte takto: ... nebo ještě lépe takto: (...). Zachovejte i kontext citace, a to nejen co se týče gramatického tvaru věty, do které ji vkládáte, ale i co se týče obsahového zaměření.

Ve zdravém těle zdravý duch je všeobecně známé přísloví. Vzniklo však z Juvenaliových satir, kde je význam vlastně opačný: Orandum est, ut sit mens sana in corpore sano čili Je třeba si př́t, aby $v$ zdravém těle byla i zdravá mysl. Tento obrat nastal spíše proto, že si výrok žil samostaně velmi dlouho, než tím, že byl poprvé špatně citován.

Pokud přebíráte z cizojazyčných pramenů, můžete text přeložit, pokud přímo nezáleží na jazykovém kontextu a potřebujete na něj odkázat. Př́kladem důsledné citace je již zmíněná kniha $H$. W. Krufta, který uváděl citáty v původním jazyce a současně je i přeložil.

3 / Necituite triviality ani všeobecně známá fakta. Že Le Corbusier navrhl vilu Savoye nemusíte dokazovat odkazem na zdroj, který to uvádí. Potvrzení, které LC napsal Eugenu Rosenbergovi do Topol'čian, že pracoval u něj (když tu vilu navrhoval), by si už zasloužilo uvést, že pochází z archivu Fondation LC.

4 / Při citaci jasně identifikujte autora a pramen. Může to být komplikované, když chcete uvést výrok osobnosti, který jste náhodou někde zaslechli, ale i zde se pokuste uvést širší souvislosti, kde 
a kdy to bylo. Těžko to Ize ověrit, ale možná někdo dokáže najít svědka, když půjde o nějaký důležitý důkaz.

5 / Pokud se uchýlíte k sekundární citaci, přiznejte to. Vždy je však lepší dostat se k původnímu zdroji. Často se tam dozvíte i jiné věci, které se vám hodí. Při zprostředkované citaci se o nich nedozvíte. Nemusíte však hledat původní zdroj při nějakém okrajovém odkazu, je to zbytečně náročné. Například už zmíněný Kruft uvádí, že i Albrecht Dürer napsal jeden architektonický traktát. Pokud nebudu hledat originál, tak ho můžu citovat zprostředkovaně přes Krufta (Dürer, Albert: ... podle KRUFT, H-W.: ...). Namísto „podle“ Ize použít i „citováno v“. To je případ, kdy prostě jen přebíráte původní výrok z druhé, ale hodnověrné ruky. Nepřípustné by to bylo tehdy, kdybyste se věnovali př́mo Dürerovi. Opačné pořadí autorů - to znamená na prvním místě Krufta - bych však uvedl, kdybych chtěl mluvit o tom, jak překvapivě kriticky se Kruft vyjadřuje o Le Corbusierovi: „Umění je nezbytnou potravou pouze pro elitu, protože nato, aby mohla vládnout, potrébuje rozjímat." (KRUFT, Hanno-Walter 1993, s. 446 podle Le Corbusier-SAUGNIER, 1969 s. 85).

\section{Citát, parafráze}

Citát je text doslovně převzatý od někoho jiného, zatímco pod pojmem citace rozumíme uvedení, od koho jsme to převzali:

„Dům je stroj na bydlení." = citát

Le Corbusier, 1939, s. $206=$ citace

Citace bývá umístěna jako poznámka v dolní části textu nebo na konci kapitoly či celého textu. Př́padně může být v závorce za citací.

Parafráze je převyprávění nějakého textu nebo jeho části. Vždy je kratší než předloha. Sáhneme k ní tehdy, když potřebujeme vložit myšlenku z toho textu do našeho výkladu a nestačí nám na to její věrná citace. Jak jsem se zmínil, stejně jako u citátu i při parafrázi dbáme na to, abychom reprodukovali citovaný názor věrně a bez zkreslení jiným kontextem. Samozřejmě, že s ním pak můžeme polemizovat, doplnit ho nebo adorovat. Parafráze však tím nesmí být deformovaná. Nejlepší je, když umíte parafrázi zformulovat zpaměti. Usilujte se dobře trefit do zamýšleného smyslu. Pokud chcete dát najevo svůj názor na to, co parafrázujete, vysuňte to mimo vlastní parafrázi.

Protože při citátu musíte důkladně uvést odkud pochází, řid'te se údaji, které jsou uvedeny na původním dokumentu. Zde se však setkáme s celou řadou detailních návodů, vysvětlení, v čem se liší od jiných a podobně. Nebudu zde uvádět malicherná zdůvodnění toho kterého systému. Když se u nás poprvé objevila mezinárodní norma a nahrazovala naši domáckou ČSN, bylo tam na jednom místě moudré konstatování, že až tak moc nezáleží na detailech, důležité je, aby citace byla korektní a aby byl v dané práci, tj. v našem př́padě $v$ disertaci, dodržen stejný princip.

Podle charakteru zdrojového dokumentu jsou tři základní typy citování, ze kterých se dá odvodit způsob citování všech ostatních: 1 / kniha, 2 / kapitola v knize nebo sborníku a 3 / článek $v$ časopise. Trochu to sice zkomplikoval příchod elektronických publikací, tam však vlastně přibydou pouze dvě věci: kde na webu jsme to našli (URL) a kdy jsme to našli (datum citace).

Dalo by se říci, že všechno ostatní je už jen odvozené. Samožrejmě autoři uvedených príruček by pobouřeně nesouhlasili a měli by po ruce kopu argumentů počínaje méně standardními dokumenty (diplomka, firemní literatura), až po úzkoprsé argumentování o úloze tečky, čárky, či dvojtečky. Zábavné je, že zmíněná mezinárodní norma musí být upravovaná na naše podmínky a že například už jen při anglickém slově citation se z něj dají odvodit dva naše pojmy (citát a citace) a přisoudit jim jiný význam. Nemluvě o tom, že norma není na webu volně přístupná, a tak si každá univerzita vytvoří svůj vlastní výklad, kde často zabloudí drobnosti z minulé verze.

Proto doporučuji

1 / především si uvědomit, které jsou ty základní, nezbytné údaje, které v bibliografické citaci musí být;

2 / zvolit takový způsob, který je nejbližší zvyklosti vaší univerzity, profesionálnímu vědeckému 
okruhu, školiteli, jiným disertacím a vám osobně je nejsympatičtějši;

3 / napsat si vzory pro způsob citování těch nejhlavnějších dokumentů, s nimiž přijdete do styku;

4 / neztrácet nervy, když budete stále narážet na nějaké výjimky a nepravidelnosti.

Tady jsou na uvedené zásady hlavní přílady a pokud možno co nejzdrženlivější výklad různých variant. Je tu řeč o formě odkazu v textu i o kompletní bibliografické citaci a jejích náležitostech tak, jak se objeví v seznamu literatury, zvaném také seznam bibliografických odkazů a podobně.

\section{Kniha}

AUTOR - název - místo - (vydavatel) - rok - (počet stran) - standardní číslo

Příklady s několika drobnými odlišnostmi, první z nich je podle dnes platné normy:

ŠVÁCHA, Rostislav. Od moderny k funkcionalismu: proměny pražské architektury první poloviny dvacátého století. Praha: Victoria Publishing, 1994. 590 s. ISBN 80-85605-84-8.

KALINA, P., Hluboké město. Moderní metropole jako Druhý Řím. Praha: Academia 2019, ISBN 978-80200-2939-3.

Dulla, Matúš - Moravčíková, Henrieta H. 2002, Architektura Slovenska v 20. století. Bratislava 2002.

DULLA, Matúš a kol., Kapitoly z historie bydlení. Praha, Nakladatelství ČVUT 2014 a 2015, ISBN 97880-01-05433-8

Rozhodněte se, zda budete zkracovat křestní jméno, jak to dělají Američané, nebo jej rozepíšete, jak to doporučuje Umberto Eco, který z rukávu vysype kopu autorů se stejným príjmením a iniciálou jména. Doporučuji rozepsat a příjmení psát verzálami. Název se zvýrazní tak, že se napíše kurzívou.

Za starých dobrých časů se ještě uznávalo, že ne všechna vydavatelství jsou stejně dobrá a informace o vydavateli se uváděla hned za místem vydání. Přimlouvám se za to.

Zvláštní pozornost zasluhuje důsledek vítězného tažení prírodních věd, kde je velmi důležité dozvědět se o těch nejaktuálnějších publikovaných výsledcích - zavedli rozlišování podle data (přesněji řečeno roku publikování). Při odkazování se pak tento rok přesouvá z tradičního místa za vydavatelem hned za jméno autora. Tak se také přesouvá v seznamu literatury, i když tady to není až tak nevyhnutné, zejména pokud jeden autor nemá citovaných více než jeden dva tituly.

$\checkmark$ jiných oborech má taková striktní orientace na nejnovější publikace menší význam. Paradoxně však vypadá, když se setkáte s například s tímto údajem: DESCARTES, 1990, anebo VITRUVIUS, 2006. To je důsledek tzv. harvardského systému citování.

Přitom tam je ještě možnost: LE CORBUSIER 1943, LE CORUSIER 1943b - to tehdy, když pilný autor publikoval dvakrát Athénskou chartu v jednom a témže roce. Pokud je tedy vaše disertace založená na aktuálních pramenech, použijte odkazování systémem JMÉNO, ROK, (strana).

Já osobně se těžko loučím s dvojtečkou za jménem autora a škodolibě sleduji vášnivé diskuse o tom, zda má být před dvojtečkou za místem vydání mezera (Praha : 2019). Lituji také nahrazení dvojtečky čárkou mezi více autory. Může to znejasnit, kdo všechno vlastně je tím autorem. Například $v$ tento př́pad je dost nejasný, když nejsou jména autorů napsaná verzálkami ${ }^{62}$ :

Kalina, Pavel, Leon Batista Alberti a Benedikt Ried. In: Daniel, Ladislav, Pelán Jiř́, Salwa Piotr a Špilatová, Olga (eds.): Italská renesance a baroko ve střední Evropě. Olomouc, Universita Palackého 2005, s. 21-32. ISBN 80-244-1152-0. 
Všimněte si, že jsem v prvním příkladu uvedl také počet stran knihy, dnes již údaj nepovinný a tedy dost zř́dkavý.

\section{Kapitola v knize (přispěvek ve sborníku)}

Když potřebujete citovat jen jednu kapitolu z knihy nebo jeden přispěvek ze sborníku, uved'te autora a název kapitoly (př́spěvku) a In: za které dejte údaj o knize jako celku, tak, jak je uvedeno o kousek níže. Seriózní autoři zde uvádějí nejen celkový počet stran knihy, ale i strany, kde se citovaný příspěvek nachází. Dnes se však už uvádění počtu stran knihy nepožaduje. Škoda, je to výborná informace o tom, zda je dílo je rozsáhlou monografií (např́klad Kruft, 1993, 703 s.), nebo jen útlou brožurou (např. Cílek, 2016, 17 s.)

To jsou základní informace, které jsou však skryty i za tzv. mezinárodním standardním knižním číslem ISBN (International Standard Book Number), které dnes dostane každá kniha. Je to číselný kód určený pro jednoznačnou identifikaci knižních vydání, který koncem 60. let zavedli v Británii a v Československu se rozšíril od konce 80. let minulého století. Starší knihy tedy tento kód nemají.

Zde je př́klad kapitoly v knize, když chcete odkázat na myšlenku, kterou najdete v jedné kapitole:

KRATOCHVÍL, Petr: Budování státu a meziválečného moderní architektura. In: KRATOCHVÍL, Petr (ed.): Velké dějiny zemí Koruny české - Architektura. Praha, Paseka 2009, s. 625-659, ISBN 97880-7432-001-9.

Katalog Národní knihovny tady uvádí jako editorku Kláru Benešovskou, ale mýlí se. Přímo na přebalu je totiž zkratka „ed." uvedená u jména P. Kratochvíla. On to byl, který knihu sestavil z př́spěvků kolegů a napsal do ní zmíněnou poslední kapitolu. I taková slovutná instituce se může splést.

Takových chytáků je při důkladném uvádění zdrojů skutečně hojně a je to pole, na kterém se může doktorand nejen učit, ale také napravovat chyby při bibliografických citacích jiných - můžete například doplnit údaj, na který jste sami přišli. Já jsem takto např́klad nedávno do hranatých závorek vložil informaci o nepochybném autorovi:

Š -. [ŠILINGER, Klement]: Univerzitní kolej na Lafranconi v Bratislavě. Slovenský stavitel' 1, 1931, s. 170 .

To byl však už odkaz na časopisecký článek, ke kterému se hned dostáváme.

\section{Článek v časopise}

Základní údaje, které je třeba uvádět při citovaní článku v časopise, jsou:

$$
\text { AUTOR - název článku - název časopisu - ročník - rok - číslo - strana od-do }
$$

Interpunkční znaménka jsou tady dost rozkolísaná. O patáliích s dvojtečku jsem se již zmínil, pomlčku mezi více autory nahradila už dnes čárka. Nejnověji se zde už také objevuje to záhadné „In:“ (před názvem časopisu), což je škoda, protože se tím dal dobře rozlišit příspěvek v časopisu od kapitoly v knize či statě ve sborníku - kde se In tradičně vkládalo. Aby to však bylo jasné také v tomto typu písma (je to Calibri), není to el-en ale i-en. Mezi oběma písmy je jenom malý rozdíl, malé el je vyšší než velké i: Il. Ale to je jenom na ilustraci toho, k jakým drobnostem se tady dá dostat.

Já sám mám ještě jeden mezinárodní problém s pomlčkou mezi číly, které udávají strany oddo. $V$ slovenštině má být před a za pomlčkou vždy mezera, tedy např́klad $265-268$. $V$ češtině je to úspornější, bez mezer, tedy 265-268, The Chicago Manual of Style je ešte stručnejší: 265-68.

Zde je příklad, který jsem převzal i s detaily, a tudíž se mírně liší od toho způsobu, který já sám používám: 
MAIER, K., 30 let Prostorové plánování v Česku - úspěchy, prohra, kompromisy a nové výzvy. Urbanismus a územní rozvoj. 2019, XXII (5), 8-16. ISSN 1212-0855.

Časopisy (nazvané „seriál“) jako celky (tj. ne jednotlivá čísla, jak by se mohlo zdát podle knih) mají podobné jednotné označení jako mají knihy. Nazývá se ISSN. Vyřeší se tím potřeba identifikovat časopisy stejných názvů. Před érou ISSN se to nahrazovalo uvedením místa, kde časopis vycházel. Např́klad český architektonický časopis s názvem Projekt má ISSN 1211-9490, slovenský Projekt má 1335-2180, chorvatský má 1846-016X a někdejší polský Projekt měl ISSN 0033-8957. Existuje ještě i brazilský Projekt s ISSN 1517-9281, ten se však nevěnuje architektuře. ISSN se však obvykle neuvádí, udělejte to však v podobných nejasných případech.

$\checkmark$ časopisech se jejich název píše kurzívou, ne název příspěvku v nich.

Číslo časopisu v rámci roku se nemusí uvádět tehdy, když má časopis v jednom ročníku průběžné číslování stran. Někdy stačí za názvem časopisu uvést stručně raád čísel, z kterých vždy první je ročník, druhé je rok, třetí znamená číslo časopisu v daném roce a poslední značí strany od-do. Když chcete být důkladnější, uvádějte například, zachovejte však jednotnost:

roč. anebo Vol.

č. anebo No.

s. anebo pp.

\section{Elektronický zdroj}

Ten má samozřejmě kratší historii než ty předchozí, nicméně jeho citace se od nich liší jenom $v$ tom, že je třeba uvést ještě dva další údaje: elektronický zdroj a čas, kdy byl citován.

Zde je príklad:

VORLÍK, Petr: Český mrakodrap mezi železobetonu a ocelí. BETON - technologie, konstrukce, sanace 15, 2015, č. 3, s. 58-65. ISSN 1213-3116

Dostupné na http://www.betontks.cz/sites/default/files/2015-3-58_0.pdf (cit. 6. 5. 2020).

Někdy se elektronická adresa dává do špičatých závorek anebo se před ní uvádí „URL“ a typ zdroje: [online] nebo třeba [CD].

Pro autory disertací však třeba zvlášt́ zdůraznit, že z toho faktu, že něco je na webu, ještě nevyplývá, že je to věrohodný a vědecky relevantní zdroj. Stejně jako v klasické časopisecko-knižní době si všímejte, zda přebíráte text ze zdroje, kde se příspěvky nebo knižní tituly vědecky recenzují, kde se filtrují redakcí e-časopisu nebo e-vydavatelstvím, i to, zda jsou pozitivně citovány.

No, a ještě druhá informace se zde musí přidat, a to je údaj, kdy jste uvedený text na webu citovali. Efemérnost je zde mnohem větší než u tištěných dokumentů, ale jistě se na nějakém úložišti budou jednou dát najít i takové příspěvky, které z nějakého důvodu z ničeho nic z webu zmizí.

\section{Různé jiné}

Knihovníci řeší i otázku, zda a jak citovat i jiné než zmíněné vědecky seriózní zdroje. Uvědomují si, že má smysl informovat i o takzvané šedé literatuře. Bud'te tady však velice, velice vybíraví. I citace diplomových prací a disertací jsou už na hraně. Pokud v nich byly zásadnější nové poznatky, měli je totiž jejich autoři normálně publikovat. Připouštím však, že takové zdroje mohou být pramenem primárních poznatků na výzkum.

Někdy se stane, že cítíte potřebu citovat výrok, který jste slyšeli, ale nebyl nijak písemně zachycen. $V$ takovém případě důvěryhodněji působí, když uved'te alespoň čas a kontext, např.: „v rámci diskuse na té a té konferenci tam a tam v roce tom a tom."

$\checkmark$ některých důkladných př́ručkách najdete doporučení, jak citovat umělecké dílo:

VINCI, Leonardo da, Mona Lisa [Portrét Lisa Gherardini, wife of Francesco del Giocondo] [olejomalba]. Paris: Louvre, Department of Paintings. INV. 779. 
Možná by si architekti mohli osvojit podobný způsob, jak na svá architektonická díla odkazovat; např́klad: Apollodóros z Damašku, Pantheon, Řím, 126.

Někdy se dostanete na různé nejisté internetové stránky. Rozhodnutí, zda je zdroj, ze kterého čerpáte informace, dostatečně věrohodný, je na vás. Já tu právě nemám po ruce zmiňovanou Ecovu knížku, ale našel jsem její naskenovaný výtisk s razítkem brněnské Masarykovy knihovny na adrese: https://vdocuments.site/umberto-eco-jak-napsat-diplomovou-praci-56788860e3b41.html. Nechám stranou to, zda je to regulární vưči autorovi, ale zdá se to být věrná kopie a budu tedy s ní tak zacházet. Určitě jsou důvěryhodnější stránky těch časopisů, které podrobují příspěvky recenzování stejným způsobem, jako to dělají klasické tištěné časopisy. Spolehlivostí se vyznačují i oficiální národní weby s digitalizovanými publikacemi, na které se již po sedmdesáti letech nevztahují autorská práva.

Zmínil jsem zde podrobněji tři základní zdroje, na které se odkazuje, a několik dalších, kde jsou již možné rozmanitější způsoby, jak k jejich citování přistoupit. Zvolte si i vy ve své práci systém, který je ve svém základě konzistentní a dbejte na to, abyste ho při vytváření citací dodrželi. Můžete si vybírat také z různých systémů, které najdete na webu. ${ }^{63}$ Norma předepisuje i formální detaily stylu a interpunkce a doporučuji se jí držet. I když já jsem si tady dovolil některá vybočení, jak si jistě všimnete, když budete pozorně sledovat detaily citování v tomto textu.

\subsection{ZÁKLADNÍ TYPY CITOVÁNÍ}

Volba systému citování závisí na druhu textu. $Z$ toho hlediska se dají rozlišit tř̌i základní způsoby:

- vše do textu;

- příjmení a rok (harvardský), př́ijmení a číslo (vancouverský);

- vše do poznámek.

\section{Vše do textu}

To je způsob, který do vědecké práce vůbec nepatří a ani se nezvykne v seriózních doporučeních vyskytovat. Proč ho tedy zmiňuji? Hodí se to totiž do zcela krátkých textů a je to tak trochu trik na vpašování elementární vědeckosti do textů, které budete případně psát do populárnějších časopisů. Tam totiž redakce dbají o snadnou čitelnost a nedovolí na konci článku uvádět jakoukoliv literaturu, ba ani odkaz na grant, který vám k výzkumu přispěl. Šikovnou formulací se však dá do textu dostat pár zmínek o prameni. Naposledy jsem to zkusil (jako poloviční autocitaci) $v$ vlastivědném krajanském časopise Listy ${ }^{64}$ takto:

„Zde se jeho talent zakrátko uplatnil úspěchem v soutěži na nový evangelický kostel. Zvítězil dokonce i nad takovými skvělými architekty, jako byl např́klad Kamil Roškot. Katarína Haberlandová, která o architektově životě a díle napsala podrobnou kapitolu pod názvem Josef Marek v proudu moderny v naši knize Zapomenutá generace (Matúš Dulla a kol., Praha 2019), řiká, že to byly možná právě balkánské centrální raně křestáanské kostelíky, které ovlivnily podobu tohoto chrámu, jakou mu dal Marek."

Zde se tedy přímo při zmínce o prameni v závorce uvádějí přesnější údaje o něm. Při byt́ jen mírně větším odkazování by však byl text přetižen sekundárními informacemi, a kdyby bylo třeba zopakovat stejný pramen několikrát, bylo by to už za hranicí jakékoli přijatelnosti. Použijte tedy tento způsob pouze při zmíněných populárnějších textech. $V$ disertaci se mu určitě vyhněte.

\section{Př́ijmení a rok (harvardský), príijmení a číslo (Vancouver)}

Největší oblibě se těší systém zvaný harvardský: (Pauer, 1997). Zde se dá také uvést i strana: (Pauer, 1997, s. 56), v prrípadě, že citujete doslovně a uvádíte to v uvozovkách. Na konci článku je 
potom abecední seznam podle příjmení a let vydání. Pokud autor vydal v témže roce několik děl, dává se za rok písmeno malé abecedy: Pauer 1997, Pauer, 1997b, což je taková berlička. Někteř́ autoři dokonce váhají a nechávají rok nejen za jménem, ale i na místě, kam standardně patří, tj. za místem vydání, resp. vydavatelem. Je to trochu nesystémové, velkou výhodou však při tomto systému je volnost při psaní a odkazování. $V$ poznámkách pod čarou pak bibliografické informace nemusí být, nicméně když je tam zkrácené dáte, ulehčíte orientaci v odkazech na jiné autory.

Harvardský systém tím, že do popředí přesune rok vydání, vyhovuje přírodním vědám, kde je aktuálnost velmi důležitá. Proto je také nejrozšířenější.

Méně úspěšnou variantou byl systém vancouverský, při kterém se místo jméno-rok dával v závorce číselný odkaz na položku v závěrečném bibliografickém seznamu (seznamu literatury), např́klad (59)., př́padně i Foltyn, s. 386 (59). Na konci textu byl potom připojen seznam podle pořadí, v jakém se autor poprvé nachází v textu. Opakované citace téhož díla se odvolávaly potom na číslo první zmínky. Velkou nevýhodou bylo, že v seznamu se těžko se hledalo. Nemluvě o pracném přečíslování při nějaké změně.

\section{V̌̌e do poznámek}

Mistrovský výkon Wordu, který umí přečíslovat poznámky, ve mně vzbuzuje hluboké a trvalé sympatie $k$ tomuto způsobu. Jeho výhody spočívají v tom, že umožňuje plynulejší spojení poznámky a zkráceného odkazu na zdroj. Pokud se neuváději jen a jen nejaktuálnější zdroje, zatlačí to do pozadí (pod čáru) zmiňovanou paradoxní asynchronnost: (Vitruvius, 2012). Vkládání bibliografického odkazu do poznámek pod čarou, na které odkazuje číslování jako horní index, je při psaní ve Wordu lehké a výhodné tam, kde je více poznámek. I samotný bibliografický odkaz autor-rok se dá doplnit nějakou poznámkou, například takto ${ }^{65}$, i když by to bylo zřetelnější, kdybych tady byly poznámky prímo pod čarou. Nevýhodou je, pokud je třeba vícekrát citovat téhož autora - uvádějte tehdy něco z tohoto:

ibid (tj. ibidem - tamtéž - in the same place) anebo

op. cit. (opere citato - in the work cited), resp.

loc. cit. (loco citato - in the place cited).

Samotný strohý odkaz na zdroj může tady být zkrácený, např. jenom na př́ijmení, rok (a stranu, pokud př́mo citujete). Musí se však dát jasně identifikovat $v$ závěrečném seznamu literatury. Tyto odkazy pomáhají čitateli při orientaci - nemusí vždy sahat do závěrečného seznamu literatury. Ten je seřazen abecedně a je v něm dobré uvést podobnější údaje o prameni (jiná vydání, překladatel, originální vydání a podobně) ${ }^{66}$.

Má to nevýhodu, která se však disertací netýká: když se text má publikovat, musí se vazba mezi číslem $v$ textu a číslem pod čarou odstranit. Vícekrát jsem dostal moudré doporučení jak na to, ale vždy to zapomenu. Dělám to ručně, protože se bojím, aby mi do definitivně korigovaného textu nepronikly nějaké chyby.

\subsection{SEZNAM LITERATURY}

Na konci disertace je pak seznam použité literatury, zvaný též seznam bibliografických pramenů. Mívá však různé názvy a podle nich může mít i odlišnou sestavu. Závisí na způsobu citování a částečně i na vaší volbě. Můžete např́íklad respektovat standardní řazení údajů, aniž byste přesouvali rok za př́imení. Renomovaný časopis Umění / Art nepoužívá inverzi (nedává př́ijmení před jméno), dost to však ztěžuje orientaci. Můžete dokonce porušit normu, která požaduje uvádět standardní číslo (ISBN). Mým humanisticky orientovaným kolegům to abstraktní číslo leží dost $\checkmark$ žaludku. Nebo nad požadavky normy uvádět ISSN při časopisech.

Na závěr znovu připomínám, že názory na detailní úpravu způsobu citování a úpravu seznamu literatury se rozcházejí od redakce k redakci, od starší normy k novější. Právě proto je dobré uvědomit si to, co je při citování nezbytné. $K$ tomu přidejte to, co je třeba $z$ hlediska specifik vašeho oboru a vaší disertace, a nakonec klidně uplatněte i své osobní preference. At' už tyto návody jsou jakkoli podrobné, určitě narazíte na nějakou otázku, kterou vám neodpovídají a musíte si ji vyřešit sami. Mně se například naposledy stalo, že jsem musel rozhodovat o tom, zda použít někdejší 
modernistické manýry, pocházející zřejmě z německého úsilí zbavit se velkých písmen na začátku podstatných jmen. Tedy psát všechno, i název časopisu, jen mínuskami:

a. z. r.: j. e. koula: obytný dům dneška. nová bratislava, měsíčník nového slovenska 1, 1931, č. 2, s. 43.

Byla to recenze od autora skrytého pod zkratkou a. z. r. Ponechat to tak ve standardizovaném bibliografickém záznamu?

To byl stručný přehled formálních složitostí citování. Jestli váháte, sáhněte k bohaté literatuře, která se věcí zabývá, např́iklad k pracem Štefana Kimličky. ${ }^{67}$

\subsection{DOBRÉ RADY NA ZÁVĚR - ZA PÁTÉ}

Citujte přiměřeně, věrně a jasně.

Dodržte stejný princip.

Údaje při knize jsou: AUTOR - název - místo - (vydavatel) - rok - (počet stran) - standardní číslo

Údaje při článku jsou: AUTOR - název článku - název časopisu - ročník - rok - číslo - strana od - do (ISSN)

Kapitola v knize nebo př́spěvek ve sborníku má ještě „In:“.

Při elektronickém prameni je ještě zdroj a datum citování.

$\checkmark$ textu použijte př́ijmení - rok (- strana) a zvažte, co všechno dát do poznámek.

Sáhněte do své knihovny a vyberte pět dobrých knih nebo časopisů a odkoukejte z nich způsob

citování; bez zábran některý z nich přeberte, nebo ještě lépe: zkombinujte si svůj vlastní.

Jasnost a jednotnost citací a dobrý seznam literatury naznačují kvalitní disertaci. 


\section{ETIKA}

\subsection{NEPOKRADEŠ}

Etika vědy se točí kolem dávného Mojžíšova „nepokradeš“. Věc je však o něco komplikovanější, protože není jednoduché definovat, co je krádež v oboru, který z principu staví na předchozích znalostech, a kde „dychtit po něčem, co patři tvému bližnímu“, jak se to formuluje na konci přikázání, je v jistém smyslu v základech nového poznání. Vtipně to přibližuje jeden z Murphyho zákonů Felsonův zákon: Krást myšlenky od jedné osoby je plagiátorství, krást myšlenky od několika lidí je výzkum.

Přebírání myšlenek je součástí vědecké práce, musíte však uvést, od koho pocházejí a uvést i to, kde je najdeme v původní podobě. To je celý, zdánlivě jednoduchý princip korektního citování. Mohli byste se zeptat, proč zdánlivě? Všimněte si například jen toho Felsonova zákona. Uvádím tam nějakého Felsona, ale jistě chápete, že to autor myslel ironicky. Kdo je však ten autor? Ne, není to ani Murphy, ani Felson, je to Arthur Bloch. Bloch jen podle Murphyho pojmenoval vtipné a cynické zobecnění týkající se lecčehos, kromě jiného i vědecké práce. Teprve ted ${ }^{168}$ jsem zde umístil korektní odkaz alias citaci na Blochovou kní̌ku, v niž shrnul podobné postřehy. Nejde však o vědeckou práci a Bloch se záměrně skrývá za různá jména, např. za Felsona. Mimochodem, Murphy je skutečná postava, americký letecký inženýr (1918-1990), který prý při zkouškách zařízení na testování pilotů zjistil, že všechny senzory jsou zapojeny naopak a konstatoval centrální „Murphyho“zákon: Když se něco může pokazit, pokazí se to.

\section{Co necitovat}

Takže tu máme hned první výjimku z přísného božího příkazu důsledně citovat: necitují se všeobecně známé a banální výroky a fakta. Když budete psát o architektovi Krejcarovi, neuvádějte, že se podle R. Šváchy narodil v Hundsheime ani že Švácha píše, že Le Corbusier byl francouzský architekt švýcarského původu. Hranice, kdy už odkážete na zdroj, ze kterého daný údaj máte, závisí na miře obecné znalosti zmíněných faktů a musíte ji samozřejmě pečlivě zvažovat. $V$ textu této př́ručky jsem mnohokrát použil citáty, které jsou obecně známé nebo jsou ze zdrojů, které je dost volně připisují různým osobnostem. Někde uvádím i rady, které mají takový obecný charakter, že jsem ustoupil od přísnějšího vědeckého způsobu citování. $K$ postřehu o tom, že televize nám obvykle nedovolí ríci více než tři věty, jsem dospěl sám, ale setkal jsem se s ním ještě na dalších čtyřech místech. Dovolil se si je necitovat. Nahlédněte do poznámky pod čarou, jaká by to byla záplava dat. ${ }^{69}$ I při nejdokonalejším citovaní se vynoří otázka o jeho hranicích a smyslu, podobná té, jakou si položil profesor Kalina: „Většinou ani nikoho nenapadne se ptát, kdo všechny ty tituly vlastně čte, jako kdyby jejich adresáty ani nebyli lidé, ale jakési zdokonalené stroje, biologické computery. ${ }^{\text {"70 }}$

\section{Plagiát}

Opsání, aniž jste uvedli autora, je hlavní přečin a jmenuje se plagiátorství. Může mít různé odstíny a kromě doslovného odepsáni cizího textu a vědomého vydávání ho za vlastní jím může být také:

- publikování cizí práce, i té nedokončené;

- vydávání kompilace za vlastní výtvor;

- provedení názvu nebo obsahu cizího textu, převzetí ilustrací, fotografií nebo grafů bez uvedení autora;

- stažení cizí práce z webu a vydávání za vlastní;

- záměrné neuvedení použitých pramenů.

Plagiát se může přihodit nevědomky tehdy, když se ztotožníte s jiným názorem, zapíšete si ho nedůsledně a při zpracování závěrečného textu ho prostě sepíšete v přesvědčení, že píšete názor vlastní. To je pouze nevědomé plagiátorství, ale nic to nemění na jeho neprípustnosti. Vyvarujte se 
proto nedůslednosti při poznamenávaní názorů a zapište si při nich nejen celé jméno autora, ale i místo, odkud čerpáte. $V$ okouzlení hlavní myšlenkou, kterou si chcete poznamenat, se to zdá být práce otravná. Vyplatí se však při závěrečném sestavování textu; ušetří vám totiž kopu vzácného času, který místo pracného hledání stran, odkud daný citát je, můžete využít na zásadnější věci.

Osvědčilo se mi tu dvojité poznamenávání si kompletních údajů: podrobný údaj o prameni na samostatný lístek nebo do jedné databáze a při vlastním citátu si pak už jenom poznamenám autora, rok a stranu. Při finálním psaní pak do hrubě nahozeného textu doplňuji detaily z podrobných bibliografických záznamů. Pokud si poznámku dělám na počítači, můžu si však i na kartičky citátů překopírovat kompletní údaje o zdroji. Mám-li to dělat ručně, je to únavné opakované psaní.

Při plagiátorství se nejednou setkáváme s falešnou výhradou, že dnešní požadavky jsou náročnější a starší publikace jim nemohly vyhovět. Kromě toho může mít různý rozsah, a ne vždy je možné jednoznačně dokázat záměrné podvádění. Nedávno se odehrál na pražské UK př́pad, kdy skupina studentů důkladnou analýzou a porovnáním textu dokázala plagiátorství prorektorovi univerzity. Ten psal o anglickém středověku, kde je již mnoho výkladů ustálených, takže by se mohlo zdát, že bude vyšší i frekvence podobných nebo stejných formulací v textech o něm. Studenti však dokázali nejen to, že části textu jsou prostě prímým překladem jiné anglické knihy, ale že $v$ textu jsou drobnými úpravami zastřené i stejné odkazy na prameny, jsou tam celé úseky stejných poznámek a podobně. Rozsah odpisování byl takový, že překročil jakoukoliv přijatelnou hranici možné podobnosti textu o známém předmětu. I tak si však důkaz o skutečném plagiátorství vyžádal poměrně rozsáhlé dokazování. Prorektor byl nucen odstoupit a odejít z univerzity.

Po tyto dni právě vrcholí kauza plagiátorství diplomové práce současného předsedy slovenského parlamentu. (Pravda je, že podobně opisoval také jeho předchůdce.) Údajně je v ní opsáno bez uvedení autora 24 procent textu. I kdyby se antiplagiátorský sofvér mýlil a někde je ten vykradený autor nenápadně uveden, i tak je opsání čtvrtiny textu za hranicí jakékoliv prípustnosti. Když mi kontrola hlásí dvě tři procenta podobnosti práce, kterou posuzuji, už pozorně sleduji, jak bylo s těmi převzatými texty naloženo, jestli a jak byli citováni jejich autoři.

\section{Parafráze}

Často se, zejména v přehledu současného stavu problematiky, $v$ disertaci uvádí stručný přepis názorů jiných autorů. To je parafráze. Jak jsem už uváděl v předchozí kapitole, určitě by měla být kratší než originál a při delších úsecích nezapomínejte odkázat na to, že něčí názor sdělujete. Když parafrázujete několik odstavců bez upozornění, o čí názor jde, matete čtenáře. Podobný zmatek nastává při dlouhých citátech, i když jsou důsledně vloženy do uvozovek - někdy se stane, že se na ty závěrečné uvozovky zapomene a čtenář si je musí domýšlet.

Při parafrázování samozřejmě často použijete stejná slova, jaká použil originál. Jsou to zejména běžnější výrazy, někdy i části vět. Vždyt' nakonec někde uvedete, od koho jsou ty uvedené myšlenky. „Důkaz o tom, že jsme postupovali správně, ziskáme tehdy, pokud dokážeme provést úspěšnou parafrázi, aniž abychom měli výchozí text před očima, "připomíná U. Eco. ${ }^{71}$

Součástí parafráze mohou být i prímé citáty, z nichž vynecháte odbočky a méně vhodné části. Dejte však pozor na to, abyste autorovi nepřipsali názor, který nezastává, když jen referuje o tom, že se takový názor vyskytuje. S tím se někdy setkám při zkoušce: student si přečetl mou knižku a uvádí jako biblickou pravdu něco, co jsem tam nejistě zmínil jako př́padně možné.

\section{Kompilace}

Pojem kompilace má negativní odstín, ale to neznamená, že odborná nebo vědecká práce tohoto druhu nemá svůj smysl. Pod kompilací se rozumí text složený z myšlenek a závěrů, jakýsi uspořádaný kaleidoskop parafrází. Není zde žádný originální autorský přispěvek, je to pouze složenina ze známých faktů a názorů, která dává obraz o dané problematice. Pokud se taková směs nevydává za originál a správně cituje zdroje, ze kterých čerpá, může být dobrým příspěvkem k poznání. Vždyt' vlastně v úvodní části každé disertace musí její autor vytvořit právě takový přehled, na kterém pak postaví svůj vlastní výzkum. Hranice mezi pasivní kompilací a sestavením známých věcí nanovo není 
striktní. I kvalitní kompilace může předčit takovou práci, která se jenom tváří, že kypí inovativními myšlenkami.

\section{Second hand}

Někdy se nedostanete k primárnímu zdroji a stojíte před otázkou, jak citovat takový zdroj. Když půjde o Vitruviovo utility, firmitas, venustas, nemusíte odkazovat na originál, pokud však budete zkoumat něco detailně, pokuste se získat původní zdroj. Nejednou tam najdete různé další fasety a významy autorových myšlenek, kterými můžete lépe podpořit své argumenty. Když např́klad D. Bořutová psala o Dušanovi Jurkovičovi, studovala v archivu uložené originály jeho poznámek o aktuálním dění a na nich založila své úvahy o jeho odpovědném skeptickém pohledu na situaci $v$ tehdejší architektuře. Ba dokonce i jeho dobově pochopitelný obdiv vůči tehdejší Itálii, který jako by narušoval heroický obraz, který jsme si o Jurkovičovi utvořili: „Rozdíl mezi naší demokracií a italským fašismem je rozdílem mezi státem, kde vládne kapitál, státem jako u nás, a kde stát vládne kapitálem..."72

Někdy odhalíte jemné rozdíly v kontextu. Např́klad posunutí významu okřídleného Marxova výroku: „náboženství je opium lidstva“ - když prozkoumáte skutečné odstíny textu, ve kterém ho filozof použil, vysvitne, že si výrok začal žít svým životem a posunul se hodně do protináboženské polohy:

„Náboženská bída je jednak výrazem skutečné ekonomické bídy a jednak protestem vůči skutečné bídě. Náboženství je povzdech utlačovaného tvora, cit bezcitného světa, duch bezduchých poměrů. Je to opium lidu. Zrušit náboženství jako iluzorni štěstí lidu znamená žádat jeho skutečné štěstí..." ${ }^{\text {"73 }}$

Na samotného Marxe se však také svezla kritika za tendenční citace: z vládních anglických zpráv o postavení dělníků vybíral jen negativa a pozitivní trendy zamlčel.

Našli bychom i př́klady z našeho oboru: Le Corbusier převzal z Gropiovy stati o průmyslové architektuře z roku 1913 fotografii amerického obilného sila, a protože chtěl dokázat americký důraz na účel, odstranil z něj retušováním historické prvky. ${ }^{74} \mathrm{Kde}$ je hranice mezi uměleckou licencí a vědeckou či prostě lidskou korektností?

\subsection{OD OMYLU K PODVODU}

Ve vědě se vyskytují jevy, které jsou prostými nedorozuměními, čestnou obhajobou později vyvrácených názorů, ale také lži více nebo méně vědomé. Odpor nositele Nobelovy ceny Philippa Lenarda proti einsteinovské fyzice asi nevznikl jako vědomý omyl nebo jako záměrné zastírání pravdy. I Mičurinovy výzkumy máme dnes tendenci zařazovat na roveň Lysenkových zřejmých podvodů. A co bylo Teigeho přesvědčení o tom, že rodinné domy zaniknou - byl to nezáměrný omyl anebo ideologizující levicová taktika čili klamství?

\section{Predátorské časopisy}

Rozšiřování pochybných vědeckých výsledků napomáhají dnes tzv. predátorské časopisy. Využívají inflaci příspěvků, která stoupá proto, že při mechanickém hodnocení výsledků výzkumu převažuje množství nad kvalitou. Těží zisk z poplatků za publikování, z poptávky autorů po publikačním prostoru a po co nejrozsáhlejším publikování, za které jsou hodnocení. Dnes se e-časopis poměrně snadno založí i vydává. Takoví vydavatelé se dají poznat podle toho, že neuvádějí přesnou adresu sídla a vydavatele, ediční rada pưsobí anonymním dojmem, neadresně rozesílají výzvy k publikování za poplatek, tváŕí se, že jsou regulárními časopisy tak, že napodobují zavedené názvy takových časopisů a názvy databází, které je sledují. Knihovník Jeffrey Beall z Univezity of Colorado v Denveru začal v roce 2010 takové časopisy sledovat, upozorňovat na jejich nekalé praktiky a vypracoval jejich seznam.

Charakteristické je, že v oblasti architektury je tento fenomén vcelku neznámý. Architekturu jednak až takové vědecké bujení nezasáhlo a jednak se zdá, že je tu přece jen vyšší citlivost vůči autorství a autorská korektnost. 


\section{Ověřování originality}

Masovost současných vysokých škol a rozmach vědecké produkce vedou $k$ tomu, že při běžných kvalifikačních pracích studentů Ize těžko očekávat, že budou všechny vědecky průlomové. Internet nabízí možnost snadno se dostat k zdánlivě důležitým informacím a jejich překopírováním a skloubením vytvořit nějakou konvenční textovou kvalifikační práci. Od těch, které při tom přistihli, slýcháme argumenty, že když práci dělali, neplatili dnešní požadavky na uvádění pramenů. To je holá nepravda. Platí už velmi dlouho. Odhalování politiků, kteří se $k$ takovému podvodu uchylují, je vděčná činnost novinářů, ale jak kontrolovat masu prací běžných studentů? Do určité míry to dělají profesoři, kteří nejsou až tak senilní, aby si něco z předchozích prací nepamatovali. Samozřejmě mají přehled pouze o úzkém rejstříku prací, s nimiž přišli do styku ve svém okruhu.

Na kontrolu opisování velkého formátu se zavedla počítačová kontrola originality, tzv. antiplagiátorský systém. Text se porovnává s jinými, které jsou již v databázi (repozitáři) uložené a stanovuje se míra jejich podobnosti. Výpovědní hodnota takového srovnání roste s rozšiřující se databází textů, s nimiž se práce porovnává. Pokud systém vygeneruje textovou shodu, důležité je, zda je daný text náležitě citován a zda jsou k němu uvedené zdroje. Systémy, které takové porovnání provádějí, jsou již zabezpečeny proti podvodům, například rozeznají vkládání bílých písmen mezi slova namísto mezer, co by jinak odlišilo opsaný text od původního.

Jednou se mi stalo, že systém kontroly originality hlásil o něco vyšší procento podobnosti s nějakými jinými texty. Ukázalo však, že doktorandka statečně publikovala své poznatky již během práce na disertaci, ty články už někteří i citovali, a právě ty citáty stály za tím vyšším procentem podobnosti.

$\checkmark$ dnešních komerčních časech najdete na webu i odvážné nabídky firem, které vám vypracují celou disertaci. Například podle slibně vypadající stránky https://www.podklady24.cz/ disertace v rozsahu 80 stran stojí aktuálně od 405 Kč za stranu, tedy 32400 Kč za disertaci. No nekup to.

\subsection{ETICKÉ KODEXY}

$\checkmark$ centru etiky vědy sice stojí přikázání zmíněné na začátku této kapitoly, které hovoří o nepř́pustnosti přivlastnit si cizí poznatek, ale ve vědě platí i jiné obecné etické a morální zásady. Například poučený souhlas při výzkumu týkajícího se soukromí, korektní zpracování dat, pravdivost čili nepodvádění apod.

Instituce, univerzity a výzkumné organizace reagují na novinky ve fungování vědy tím, že sestavují etické kodexy, v nichž formulují obecné etické zásady vědecké práce. Jistěže je nebudete mít na nočním stolku a nebudete je denně studovat, ale zkuste si je alespoň vyhledat na webu vlastní univerzity ${ }^{75}$ nebo se podívat, jak takový katechismus sestavili jiné univerzity ${ }^{76}$ či Evropská unie. ${ }^{77}$

\subsection{DOBRÉ RADY NA ZÁVĚR - ZA ŠESTÉ}

Přečtěte si a dodržujte etický kodex vaší univerzity.

Citujte důsledně.

Uveřejňujte jen pravdivé oznámení - pravda vítězí.

Respektujte spoluautorství i pořadí autorů, autory vždy uvádějte.

Vlastní musí převažovat nad převzatým.

Pozor na plagiátorství, i nevědomé.

Nepublikujte totéž opakovaně.

Co najde doktorand, najde i pedagog. 


\section{PSANÍ}

Zda ten, kdo piše, piše dobře nebo špatně, to se zjistí hned, ale zda ten, kdo nepiše nic a klidně si sedí, sedí si klidně z moudrosti nebo z hlouposti, to žádný smrtelník nezjistí.

G. Ch. Lichtenberg

\subsection{CO JE DISERTACE}

Český zákon o vysokých školách ${ }^{78}$ je v popisu toho, co je disertace, stručný: „Doktorský studijní program je zaměřen na vědecké bádání a samostatnou tvưrčí činnost v oblasti výzkumu nebo vývoje nebo na samostatnou teoretickou a tvưrči činnost v oblasti umění... studium se ukončuje státní doktorskou zkouškou a veřejnou obhajobou disertační práce, kterými se prokazuje schopnost a připravenost $k$ samostatné činnosti v oblasti výzkumu nebo vývoje nebo $k$ samostatné teoretické a tvưrči umělecké činnosti. Disertační práce musí obsahovat původní a zveřejněné výsledky nebo výsledky prijaté k uveřejněni."

Podrobněji o disertaci říká předpis ČVUT: „Disertační práce je výsledkem rešení konkrétního vědeckého problému nebo uměleckého úkolu specifikovaného v cílech disertace; prokazuje schopnost doktoranda samostatně tvůrčím způsobem pracovat a musí obsahovat původní autorem disertační práce publikované nebo k zveřejněni prijaté výsledky vědecké nebo umělecké práce. " 799 Přičemž: "za disertační práci lze uznat i soubor publikaci nebo príijatých rukopisů, opatřených integrujícím textem."

V slovenštině se místo doktorský používá jemnější odlišení: doktorandský. Definice tohoto studia je podobná české: „Doktorský studijní program (...) se zaměřuje na získání poznatků založených na současném stavu vědeckého a uměleckého poznání a zejména na vlastním příspěvku studenta $k$ němu, který je výsledkem vědeckého bádání a samostatné tvưrči činnosti v oblasti vědy nebo techniky nebo samostatné teoretické a tvưrčí činnosti v oblasti umění."

Připouštějí se úpravy tématu disertace. Na ČVUT „nejpozději na konci studijního bloku na základě předložené studie a rozpravy o tématu disertačni práce", na STU se při změně vyžaduje souhlas oborové rady.

Disertační práce na STU má obsahovat analýzu aktuálního stavu poznání v dané problematice, charakteristiku cílů, podrobný popis použitých postupů (metod práce, materiálu), dosažené výsledky, jejich vyhodnocení, diskusi, závěr a seznam použité literatury. Doktorand však může předložit jako disertační práci i vlastní publikované dílo nebo soubor vlastních publikovaných prací, které svým obsahem rozpracovávají problematiku tématu disertační práce. $V$ takovém případě ho doplní o části, ve kterých uvede současný stav problematiky, cíle disertační práce a závěry. Disertace nemusí nutně být individuálním autorským dílem. Pokud je součástí kolektivní práce, doktorand uvede vlastní výsledky a v diskusi je dá do kontextu s výsledky ostatních členů kolektivu.

\section{Postup psaní}

Mohlo by se zdát, že samotné psaní disertace má být jen ta hektická činnost, na kterou si necháte poslední týdny před nejposlednějším termínem odevzdání. Je to chyba ze dvou důvodů. Zaprvé odložit psaní na tak zničující krátký čas je beznadějné a zadruhé absence psaní v průběhu celé práce se ve výsledku vymstí a na disertaci je to vidět. Pište od samého počátku výzkumu. $\vee$ napsaném textu, byt' jen útržkovitém a prozatímním, dobře spatříte mezery, chyby. Při zpětném pohledu na něj uvidíte i cestu a slepé odbočky, ke kterým jste se dostali a na které byste jinak zapomněli. Já sám už mám s psaním nějaké zkušenosti, ale vždy jsem litoval, když jsem se př́liš spolehl na to, že věc prostě napíšu zpatra. Jeden za druhým se mi v textu objevovaly problémy, nevyřešené otázky, nejasné odpovědi - to, čemu jsem se měl věnovat již dřive. Připomnělo mi to Škvoreckého výrok: „Nikdo neví líp než spisovatel - nemyslím tím génia realismu, ale nás, prosté přidávače - jaký je to problém; jak naše "umění tak často spočívá v umění obratně zatajit, co všechno o životě nevíme".80 
Jednou jsem v zoufalém nedostatku času použil takový trik, že jsem celý referát sestavil pouze z otázek, které přede mnou vyvstávaly při tom nepřipraveném psaní. Ale nebyl to čestný přístup a určitě se při psaní disertace nedá použít. Přiměřenou dávku dotazů si třeba nechat na závěrečnou kapitolu zvanou diskuse, ale nedá se jimi prošpikovat celá disertace, aniž by nabízela i nějaké odpovědi.

\section{Prokrastinace} realizoval.

Projekt je velkolepý podnik, který je natolik široce koncipovaný, že je vyloučeno, aby se

\section{Daniel Defoe}

Disertant je od počátku postaven před úlohu, kterou dosud neznal: má před sebou úlohu formulovanou pouze jednou dvěma větami a může jej řešit neuvěřitelně dlouhou dobu: čtyř i více let. $S$ takovou volností se ještě nesetkal. Běžné studium bylo svázané a řízené rozvrhem hodin a termíny. De facto bylo naprogramováno na roky dopředu.

Jiné povinnosti jsou vcelku malé a dosti vzdálené od vlastního tématu (například povinnost vyučovat). Oficiální časový plán je dosti matný, přísnější je jen v prvních semestrech, kdy se očekává absolvování pár předmětů. Čím více se blíží finále, tím je volnější. Práce na disertaci je tedy věc velmi individuální a povinnosti časově neurčité. Právě tehdy nastupuje do popředí známá lidská vlastnost, která se nedávno začala učeně nazývat prokrastinace.

Zdlouhavé zabývání se malichernými věcmi a odkládání těch velkých známe všichni. Psychologové se však tohoto tématu ujali s nadšením hodným lepší věci a z množství jejich studií jako by pro nás vyplývalo ospravedlnění: odkládat důležité věci je přece lidsky přirozená vlastnost. Americké univerzity mají na webu obšírné návody na to, jak prokrastinaci překonat. Někdy mám dojem, že už jen samo čtení těchto textů může načisto znemožnit vlastní práci na disertaci.

John Perry, autor jednoho z takových (vtipných) návodů, přišel s originálním řešením: podle něj je omyl snažit se minimalizovat své závazky tak, abychom před sebou měli jen několik věcí. Správně je dát si do popředí seznamu úloh takové, které mají:

1 / jasně dané termín dokončení (ve skutečnosti se však dají odkládat);

2 / zdají se nesmírně důležité (ačkoli ve skutečnosti nejsou).

Perry tvrdí, že když si vysunete do popředí právě ty zdánlivě důležité věci, přirozenou prokrastinační tendencí bude, že se začnete zabývat těmi, které jsou v seznamu za nimi, a tak dojde na věci skutečně důležité a snad dojde i na disertaci.

\section{Harmonogram práce}

Méně vtipné, ale reálnější řešení je sestavit si vlastní plán neboli harmonogram práce s dostatečnými rezervami. Vždyt' i při každé grantové žádosti je třeba vyplnit část, kde se má stanovit harmonogram řešení projektu. Rezervy jsou důležitá věc; velmi těžko se totiž dají předvídat překážky, které práci zdrží a při závěrečném psaní se to projeví nejvýrazněji. Podceňování časové náročnosti budoucích činností je součástí psychické výbavy každého z nás. Jak říká Hofstadterův zákon: Vždy to trvá déle, než očekáváte, a to i tehdy, když vezmete v úvahu Hofstadterův zákon. ${ }^{81}$

Psycholog Daniel Kahneman uváděl, že kdysi pracoval jako předseda komise na změnu školních osnov v Izraeli a zeptal se kolegů na jejich odhad, jak dlouho bude komise pracovat. Domnívali se, že dva roky. Na dotaz u zkušeného člena, jak dlouho je zvykem pro takové komise pracovat, dostal však odpověd', že to nikdy není méně než sedm let, některé pracovaly až deset let. Komise však setrvala v optimistické představě rychlého výsledku. Ve skutečnosti však působila osm let a když projekt skončila, ministerstvo o výsledek její práce ztratilo zájem. ${ }^{82}$

Nadměrná sebedůvěra není však jen výsledkem takového komisního optimismu, je nám individuálně vrozená. $K$ našemu překvapení je vyšší u odborníků než u laiků a větší u mužů než u žen. Obecně velmi optimistické jsou představy o úspěchu složitějších projektů sestávajících z více samostatných kroků. Když je těch kroků deset a každý má 90procentní šanci na úspěch - což se zdá poměrně vysoké číslo - je údajně až 65 procentní pravděpodobnost, že projekt selže. 
Složitému projektu se podobá plán disertační práce. Zde je přímo železným pravidlem, že se původně zamýšlená šířka tématu musí redukovat a čas potřebný na její závěrečné zpracování se natahuje podobně, jako práce zmíněné Kahnemanovy komise.

Sestavit si harmonogram na samém začátku práce se možná zdá být vařením z vody. Ale právě zde využijte svou úplnou nejistotu a sestavte si ho se spoustou rezerv. Pokud se vám podaří provést některý úsek rychleji, je to velmi povzbudivé, pokud ne, máte $k$ dispozici rezervu. Nemluvě o tom, že se k plánu můžete vracet a upravovat ho. Např́iklad na konci roku, kdy se mají dělat zásadní novoroční předsevzetí.

Na takové plány je prý na webu obrovské množství moudrých a promyšlených aplikací. Ti, kteři mají sklon k jejich využívání, at' se dají touto cestou. Ale připomínám, že ztratíte výhody, které poskytuje zmiňované gumování a přepisování textu napsaného tužkou na papíře.

\subsection{PRACOVNÍ OBSAH DISERTACE}

Když dnes čtu návody, jak si nakreslit „,myšlenkovou mapu“ nebo jak si lepit témata powerpointové přednášky psané rukou na barevných samolepících papírcích a přesouvat si je při postupném precizovaní celku, nemohu se ty zdánlivě překonané tužky, gumy a papíru nezastat. Já sám jsem si strukturu této knížečky schválně nakreslil jako velké ovály vyplněné názvy podkapitol; jen jsem zaváhal, když jsem si ty ovály nakreslil perem. Myslel jsem si, že je už mám jasné. Později jsem však usoudil, že nemusím do samostatné kapitoly vyčleňovat citace a že spojím témata obhajoby, přednášení, publikování a popularizace do jedné kapitoly. Kdybych měl i ty ovály tužkou, přegumoval bych to a snadněji přepsal. $A$ ještě bych tam měl stopy po tom původním řešení. Co když se $k$ němu nakonec přece jen vrátím? (A opravdu, nakonec jsem ty části znovu rozčlenil.)

To se týká i rady vytvořit si co nejdříve pracovní obsah disertace. Neměl by to být jenom soupis názvů kapitoly (např. Metoda výzkumu), ale stručně a „tématicky“ zde napište pár vět o tom, co bude $v$ těchto kapitolách. Sami si ujasňujete, co vlastně chcete dělat. Je to strukturovaný text, ve kterém se už konkrétněji, byt' pouze na hypotetické úrovni a na základě nejistého úvodního poznání, hovoří o věcném obsahu:

$\checkmark$ práci chci dokázat toto a toto tvrzení. Souvisejícími oblastmi se zabývali ti a ti autoři a dospěli k takovým a takovým výsledkům. Mého problému se dotkli ti a ti autoři a ř́kají to a to.

Řešení má smysl takový a takový, přispěje k tomu a tomu. Budu zkoumat tyto a tyto objekty.

Metoda, kterou použiji, bude založena na takových a takových postupech (na získávání nových poznatků průzkumem v archivech, na porovnávání rozdilu starších a novějších děl, na analýze dosud neznámé korespondence autora s klientem ...)

$\checkmark$ první kapitole rozeberu to a to, $v$ druhé kapitole se pokusím objasnit tu a tu skutečnost, ve trétí kapitol se budu zabývat tím a tím vztahem.

Nakonec shrnu, že výsledky celkového řešení vytyčeného problému jsou takové a takové.

$\checkmark$ diskusi vymezuji, jak se dají zobecnit má konstatování, pokud se dají vztáhnout na takový a takový okruh architektury toho a toho období. Dále určím, že zpřesněni a rozšíření poznatků, které jsem získal, by se dalo dosáhnout takovým a takovým způsobem.

Mé výsledky je možné využít v té a té oblasti.

(Za takto a takto si pravda vždy dosad'te, pokud možno, co nejvěcnější informace týkající se předmětu vašeho výzkumu.)

Takže např́klad konkrétně v části Metoda by bylo uvedeno, že se budou zkoumat excelentní zahraniční realizace nejlepších architektů a pak se z nich odvodí to, co se dá v našich skromnějších podmínkách uskutečnit. Př́padně se ještě doplní, že takových veleděl je několik zejména ve Francii a v Británii a že z nich je možné navštívit a získat potřebné informace asi tak čtyři, pět. Takové úvahy jsou úplně svobodné, můžete je měnit či mazat a přepisovat, kdy chcete. Ale už jen z této formulace je zřejmé, že je třeba nejen navštívit, ale také získat nějaká fakta o těch čtyřech či pěti objektech. 
Můžete dále pokračovat, např́iklad celkem předběžným určením toho, jaká fakta vás budou zajímat, a tak se před vámi vynoří otázka, zda jsou v té Francii nebo Británii dostupná a podobně.

Tento předběžný obsah není časový harmonogram, začít Ize totiž od nejznámější části problematiky nebo od té, na niž se už pracovalo. Uvedený způsob je užitečný i při sestavování grantových žádostí. Já sám si pak k takovému pracovnímu obsahu zvykl důsledně přiřazovat skupiny kartiček a označuji je podle zařazení v pracovním obsahu.

Už jen sám takový pracovní obsah hodně napoví o tom, co nevíte, co musíte zjištovat. Dává představu o limitech a o čase, který na dané činnosti bude potřebný. Ta je zpočátku mlhavá, ale postupně se takto stává přesnější a přesnější.

$\checkmark$ takto formulovaném obsahu by již měly být odkryta zákoutí jednotlivých kapitol a mohli bychom ho považovat za instruktivní úvod celé disertace.

Že je ještě mnoho toho, co nevíte? Nevadí, zkuste to formulovat odhadem. Postupně s tím pracujte, přepisujte to, přesouvejte jednotlivé části na jiné, vhodnější místo, doplňujte nové informace a nové vlastní poznatky. Psaní disertace začíná již na samém počátku prací, není to jen závěrečná nepř́ijemná povinnost. Možná že jsou mezi námi i Mozartové, kteří bez chyb a z patra napíší bezchybné partitury, ale my „přidávači“ musíme mnohé věci opravovat, gumovat a přepisovat.

\section{Co psát nejdřive}

Takto postavený pracovní obsah nemusí předurčovat chronologii vašeho výzkumu a už vůbec ne sled, $v$ jakém budete psát vlastní disertaci. Dokonale připravená disertace se snad dá psát od začátku po konce postupně, ale která je připravena dokonale? Proto můžete začít nejdřive tou kapitolou, kterou dokážete napsat nejsnáze. Dokonce ani závěr nemusíte psát na konec, ale měli byste ho revidovat podle toho, co vlastně obsahuji (nebo neobsahují) předchozí kapitoly.

Protože se doktorand v prvních fázích práce má zabývat výzkumem toho, co už vědí jiní, mohla by být nejdřive napsanou kapitolou ta, kde se probírá současný stav problematiky a uvádí se zde přehled literatury, která se vašemu problému již věnovala. Ale i zde platí, že tento text nemusí být první v pořadí a můžete ho zpracovávat až poté, co si ujasníte své výsledky a podle nich pak uvedete i souvislosti s ostatními dosavadními poznatky.

\section{Způsob psaní}

Piš, aby ses vyjádřil, ne aby si imponoval.

Komu vlastně disertaci píšeme? Dvěma oponentům, kteří ji mají přečíst celou? Nebo komisi, která ji prolistuje v průběhu obhajoby? Jistě lze diskutovat o tom, zda disertace, podobná rukopisu menší knižní monografie, je ten nejsprávnější způsob ukončení architektonického výzkumu. Ale přece jen se takto dá předvést schopnost rozsáhlejšího skloubení výzkumu, myšlení a psaní. Ve skutečnosti se sem tam najdou také hodnotnější práce, které si zájemci půjčí z fakultních knihoven, z hlubin děkanátních skladů anebo z univerzitních e-repozitářu.

Disertace se tedy obracejí nejen ke komisi a oponentům, ale také k širšímu publiku, které tvoří především odborníci z daného oboru, ale i ti, kteří působí v jiných oblastech. Proto by měl být jazyk, kterým se k nim promlouvá, přiměřený. Oblast architektury se zatím nevymkla z obecné zkušenosti natolik, že by musela používat $k$ dorozumívání jiný než běžný jazyk. Tak je to v matematice, logice nebo ve vědách, které zkoumají např́ílad mikrosvět - tak vzdálený od našich běžných představ. Určitě se dá poznat rozdíl ve vědeckém a populárním jazyku, ale tak, jak se projektující architekt vždy obrací de facto $k$ uživateli jako $k$ laikovi, používá se i v našem vědeckém oboru jazyk blízký obecnému jazyku.

Srozumitelnosti výkladu je možno dosáhnout i v textu, ve kterém se vyskytují nějaké specifické pojmy. Na jejich vysvětlení použijte přiměřené definice. Respektujte však obvyklé významy slov, které jsou běžně přijaté a samozřejmé, nepropadejte mánii zdánlivě originálního a nového definování pojmů tam, kde je to nadbytečné.

Do našeho jazyka proniká v současnosti mnoho anglicismů, zejména proto, že jsou krátké, mají zažitý kontext $v$ anglickém a americkém prostředí, a proto, že mnohdy pojmenovávají zcela nové 
skutečnosti, zejména v oblasti informační techniky. Čeština jako jazyk malého společenství má s těmito vlivy bohaté zkušenosti, zápasila již s germanismy, množství stop v ní zanechala latina. Určitě se dnes nelze puristicky izolovat od anglicismům tak, jak se bojovalo s germanismy. Ale doktorand, který je často první, kdo se zabývá novým jevem, by mohl být tím, kdo nabídne český ekvivalent, místo toho, aby hrdě oznámil, že slova jako cohousing, schwarzplan, brownfield, CAD nebo BIM jsou nepřeložitelná. Benjamin Fragner mi jednou ř́kal, že mu je byl sympatický pokus namísto brownfield použít hezký český ekvivalent průmyslový úhor, ale přišel pozdě, anglicismus už byl ve veliké módě.

$\checkmark$ technických vědách je vztah mezi jazykem a kulturou zprostředkovanější. Jazyk není tak podstatný při koupi auta nebo při interní debatě IT odborníků. Ale i zde vzniká bariéra vưči těm, kterým je výsledný produkt určen, tedy vůči běžným lidem, kteří nepoužívají angličtinu nebo neovládájí IT hatmatilku. Když se to však odehrává na poli kultury, hrozí nebezpečí odtržení se elity od těch, pro které jsou výstupy jejich poznání určené. Konrad Liesmann připomíná význam komunikace a rozvíjení odborných dorozumívacích prostředků ve vlastním jazyce na všech úrovních vedení: „Kdo byl svědkem toho, jak nějaký expert zoufale hledá ve svém rodném jazyce výraz pro pojem, který je pro něj běžný pouze v angličtině, tuši, jaký vývoj se dá očekávat. Nejdřive se př́slušný terminologický pojem zapomene, pak už se neví, že takový výraz v rodném jazyce existoval, a nakonec př́slušné slovo zcela vymizí." ${ }^{\text {"3 }}$

Pokud na to upozorňuje příslušník německy mluvícího společenství, je to pro nás s našimi menšinovými jazyky mnohem hrozivější. Disertace nestojí mimo tento proces a právě v nich se může nabídnout a vydat na zkušenou ekvivalentní pojmenování pro jev dosud neznámý a v domácím jazyku dosud nepojmenovaný.

\section{Kompozice textu}

Hlavní text Ize postavit jako

1 / zprávu o zjištěných skutečnostech či závislostech, nebo jako

2 / postupný výklad, mluvení, jako by autor mluvením přicházel na věci, které v textu objasňuje.

Když budete experimentálně zkoumat, jak rychle shoři dům ze slámy na zmenšených modelech, použijete první způsob. Když budete analyzovat nějaký déle trvající děj, tak použijete nejspiše druhý způsob - např́klad při studiu rozkvětu a úpadku rondokubizmu na státních školách první republiky. Přitom zde existuje řada variant; řekněme, že postupný výklad bude formulován jako analytický príběh podobný konverzaci nebo začne nějakou záhadou a ta se postupně jako v detektivce objasňuje. ${ }^{84}$ Pokud je výzkum založen empiricky a vychází z nějakého pozorování a měření, nejdříve se nabízí metoda první. Pokud se bude disertace zabývat teoretickým problémem nebo otázkou metodologie, je k dispozici druhý způsob výstavby textu.

$\checkmark$ prírodních vědách se ustálila skladba časopiseckého článku podle modelu IMRAD, což je zkratkové slovo z iniciál anglických označení (pravda i s jejich latinským a řeckým pozadím) názvů hlavních částí textu článku:

I - Introduction čili úvod;

M - Metods nebo Metods and Materials (Zde se hovoří o metodě výzkumu a o „materiálu“ přesněji o předmětu, který se bude zkoumat.);

R-Results čili výsledky;

A je zkratka za and;

$\mathrm{D}$ - znamená diskuse.

$\checkmark$ našich poměrech však je běžnější tato struktura disertace: ${ }^{85}$

Úvod, který by měl obsahovat stručné uvedení do tématu.

Současný stav řešení problematiky a přehled literatury čili přehled dosavadní ho poznání.

Cíl práce, kde se zformulují výzkumné otázky, případně hypotézy, kterými se bude disertace zabývat.

Metody výzkumu, kde se popíše postup čili vědecké metody, které se při řešení daného tématu použily. 
Výsledky, kde se bude psát o tom nejhlavnější, čemu se disertace věnovala a na co přišla, at' už z hlediska rozšíření našeho vědeckého poznání, nebo z hlediska př́mé použitelnosti v praxi.

Závěr shrnuje to podstatné $z$ disertace a současně obsahuje i vymezení platnosti těchto poznatků.

Zde je důležité říci, že část nazvaná Výsledky je tou hlavní. Při disertaci, která má charakter narativní, je tedy jakýmsi přiběhem a nikoliv pouhou zprávou, je tato část bohatě strukturovaná. Např́klad kdyby šlo o profesionální životopis významného architekta, Ize zde vytvořit sérii podkapitol, které sledují výrazné časové etapy jeho životní dráhy (např́klad u architekta Šilingera se dá do protikladu postavit české art deco vǔči pozdějšímu funkcionalismu nebo v životopise Emila Belluše jsem mohl sledovat nejen různé stylové proudy, ale také jeho postoj vůči státům, kde mu přišlo žít a pracovat. ${ }^{86}$ Zde se „výsledky“ chápou trochu jinak než v práci, která ohlašuje lepší poznání závislosti nějakých proměnných. Např́klad výsledky zkoumání vztahu mezi velikostí okna, jeho orientací a tepelnými zisky, resp. ztrátami, jak to udělal Richard Kittler v článku nazvaném Okno ako architektonický prvok a energetický problém ${ }^{87}$

Když mám jako oponent v rukou práci poprvé, nejdříve se podívám, jaké jsou její cíle a pak otevřu závěr a zjištuji, zda disertant na ty cíle alespoň v zásadě nezapomněl, ba zda je i splnil. Užitečné je psát tyto dvě od sebe dosti vzdálené části současně a údaje v nich navzájem konfrontovat. Jinak řečeno, vynechte ze svých cílů to, co neumíte v závěru doložit jako splněné. Často je to prostě jen moudré slevení z přiliš široce a nerealizovatelně postavených cílů.

\subsection{ZÁKLADNÍ PRVKY TEXTU}

\section{Věta}

Základním kamenem textu je věta. Nespoléhejte na to, že vědecké psaní má být ze své podstaty složité, a tudiž potřebuje komplikované věty. I zde je vítaná stručnost a jasnost. Zapomeňte na archaické vyjadřování v dlouhých komplikovaných souvětích. Redaktorka naší knihy navrhla zjednodušit dlouhou větu v kapitole jednoho kolegy. Bránil se tím, že se učil latinu a věta má přece jasnou stavbu:

Profesor Alfréd Piffl, entuziasticky přistěhovalec, s jehož jménem jsou trvale spjaty rozhodné kroky podniknuté na vzkříšení v době jeho príchodu už téměř půldruhého století rozpadajícího se Bratislavského hradu, charismatický vysokoškolský učitel, jehož vládnoucí násilnická moc po vykonstruovaném procesu nespravedlivě uvěznila (1957) a natrvalo zbavila možnosti pokračovat $v$ slibně započaté výchově naléhavě potřebného slovenského architektonického dorostu, v jedné ze svých básní zanechal dvojverší: „... Já ve vězení vzpomínám a věřím, / že neztratí se, co jsem vychoval."

Nakonec jsem mu větu potají přece jen rozdělil na tři části a pokud si to v knize neověril, dozví se to, až když si přečte tento text.

Nesrozumitelnost je však spíše projevem nejasnosti ve věci samotné, nikoli znakem toho, že chybí slova na vysvětlení něčeho nevídaného. Nebojte se vysvětlit věci od základu, bud'te však opatrní, abyste neobjasňovali samozřejmosti. $V$ práci z oboru architektura nemusíte vysvětlovat, co je architektura, pouze pokud byste se speciálně zabývali odlišností její definic.

Módní smajlíky vedou často $k$ tomu, že nahrazuji v stručné komunikaci to, co netřeba rozepisovat textem. Ale zachrání smajlík vtip, který je slabý? Je to berlička, která vede $\mathrm{k}$ tomu, že se již v textu nedokážeme dobře vyjádřit. Podobnou pomůckou jsou vykřičníky. Zdaleka se jim vyhněte a nechte je pro nadpisy v bulvárních novinách. Nepoužívejte ani tři tečky na konci vět a dopovězte věty důkladně.

Píšete spíše běžným jazykem, který jen výběrově rozšiřte o odborné nebo vědecké pojmy. Ty nezapomeňte definovat, pokud nejsou samozřejmou výbavou oboru, kterému je práce věnována. 
Věty skládejte logicky, sledujte jejich návaznost. Logika stavby textu vás někdy odvede od původní představy, jak ve výkladu postupovat - přiměřeně respektujte tyto vnitřní stránky textového výkladu. Odolejte i pokušení předvést se tím, co všechno víte. Stavbu vět a jejich sled důkladně posud'te podle základního záměru disertace a vedlejší odbočky kriticky zvažte. Můžete je dát do poznámek. No, a nakonec podle Umberta Eca: „čleňme text do odstavců, a to vždy, když je to nutné, zvláště pokud to vyžaduje sled a rytmus našich myšlenek. Čím častěji tak děláme a čím více odstavců vytváríme, tím lépe. ${ }^{\text {"88 }}$

\section{Od psaného $k$ mluvenému}

„Učil jsem angličtinu ve střední Evropě a v rámci toho jsem učil i psaní. Dobře se pamatuji, jak mě přiváděli do zoufalství studenti, kteři tvrdošíjně odmítali rozdělit text do odstavců, psát tak, aby jedna věta logicky vyplývala z druhé a aby text vyjadřoval koherentní stanovisko..." - vzpomínal jeden učitel. ${ }^{89}$

Ve vědě donedávna dominoval psaný text, dnes roste význam mluveného slova a rétoričnosti (diskuse, konference, semináře, kulaté stoly, tvưrčí dílny apod.). V kontinentální evropské tradici (německé, teutonské sféře) platila v minulosti vysoká prestiž vědce, velká úcta k teorii a důmyslná hierarchičnost teoretického konstruktu. $Z$ toho vyplývaly složité a obtížně srozumitelné texty. $\checkmark$ anglo-americké vědecké sféře jsou vědecké texty blízké textům neodborným a namísto teorie zde převažuje úcta k empirickým údajům.

\section{Autorský plurál}

V disertační práci se předpokládá opatrnost formulací, autorská skromnost a tzv. autorský plurál, např.: zjistili jsme, experimentálně jsme ověřili (což znamená: já jsem zjistil, já jsem ověril). Je to vhodnější také proto, že za výzkumem částečně stojí také váš školitel.

Můžete však použít i takzvaný inkluzivní plurál čili takový, kde se počítá s čtenářem: „pokusme se z toho udělat uzávěr" apod. Samozřejmě můžete ustoupit jako autor do pozadí tak, že použijete trpné tvary, například „zjistilo se“ místo „zjistili jsme“ a podobně, ale textu to na přívětivosti nepřidá. Schovejte si jej pro případy, kdy podnět nemůžete nebo nechcete vyjádřit (protože přesně nevíte, museli byste jej opakovat atd.) Autorský plurál je samozřejmostí také při kolektivních výzkumech.

Jistě jste si všimli, že já sám v tomto textu používám singulár. Dělám to jednak proto, že se postupně od archaičtějšího plurálu ustupuje, a jednak proto, že zde podávám vlastní názory a zkušenosti, které nechci vydávat za naše.

Vzhledem $\mathrm{k}$ tomu, že disertace je přece jen dílem vědeckého eléva, u kterého se očekává větší míra pokory, je vhodnější použití plurálu. Ačkoli někteří tvrdí, že je dnes vhodné už jen pro vladaře a těhotné ženy.

\section{Odstavec}

Velmi důležitým a často dost podceňovaným stavebním kamenem textu je odstavec. Není to pouze grafické členění textu. Pojmenování odstavec má podle toho, že začíná „odstavěním“ prvního rádku. Pokud se nedělá toto odsunutí (já ho však doporučuji), je třeba alespoň kvưli přehlednosti textu zvětšit mezeru mezi jednotlivými odstavci.

Jednoduché základní pravidlo dobře postaveného textu je: co odstavec, to jedna myšlenka. Užitečné je, když je podstata této myšlenka na začátku odstavce.

Názorné učebnice někdy téma odstavce uvádějí na margu. Jsou to jakési nadpisy odstavců. To je velmi užitečné i jako dočasné označení při velkém přeskupování částí textu, anebo když na textu pracují dva nebo více autorů.

Odstavec může být postaven několika způsoby. Jeho začátek může být formulován:

1 / „In medias res" - prímočaře a bezprostředně se uvede téma, pak se rozvijí. Například:

Akvaparky jsou komplexy bazénů, koupališt', plováren a souvisejících zařizení. Vyvinuly se $z$ obyčejných víceméně monofunkčních plováren, když se zjistilo, že členitou nabídkou funkcí lze preklenout sezónnost a uspokojit rozmanitost poptávky... 
2 / „Od lesa“ - rozšířený začátek, odvolává se na něco související, až potom se uvede vlastní téma:

V článku o autobusové umývárně v časopise Projekt (5/2003, s. 56) vyložil M. Zervan své chápání architektury jako nehmotného fenoménu. Pokusím se ukázat na omyly tohoto prístupu a jejich di̊sledky.

3 / Předznamenávají - připomíná závěr, řekne se, co se všechno bude přebírat, případně i závěry:

Tato kapitola bude analyzovat funkční a velikostní typy akvaparků a jejich vhodnost pro naše podmínky. Porovnáváním stávajících řešení a dosavadních realizovaných podobných komplexů ...

4 / Přechodový - obsahuje přechod od odstavce, který ho předchází. Např́iklad takto by mohlo vypadat navázání na odstavec uvedený v bodě 2 /:

Prvním pochybným bodem tohoto prístupu je fakt, že zcela ignoruje základní význam pojmu architektura, kterým se označuje fyzicky existující objekt, stavba. Tento význam se běžně používá ...

Odstavec podle vnitřní výstavby může být stabilní, když je jeho téma stálé; rozvíjející se, kdy postupně nabývají platnosti různé stránky tématu nebo se odstavec rozpadá na několik dalších, a vyvijející se, kdy se vnitřní logikou přeměňuje na nové téma. Odstavec může končit vyčerpáním tématu anebo shrnutím. Zvláštní postavení mají odstavce na začátku a na konci kapitol. ${ }^{90}$

\section{4 ČÁSTI TEXTU}

Přibližme si funkci jednotlivých textových součástí, které tvoří disertaci.

\subsubsection{Co bývá na začátku}

\section{Název}

Název má upoutat a mluvit o hlavním přemetu zájmu disertace. První varianta názvu, jak jsem již zmínil v druhé kapitole o zrození tématu disertace, se sice objeví ještě před tím, než jsme se stali doktorandy, ale její osud je nejistý. Na rozdíl od striktně zadaných témat diplomových prací se zde počítá se zpřesňováním, přesněji řečeno se zužováním. Zápas s názvem je dlouhý a těžký. Jeho opakovaným omíláním se ztratí kritický pohled na něj a často v něm zůstávají neurčitě obecné formulace, které mají jen mlhavou výpovědní hodnotu („design v kontextu“ a podobně).

Zčásti se zúžení a jasnější zaměření tématu promítne do zrodu druhé části názvu disertace. $\checkmark$ první větě tak zůstane původní verze a v druhé se téma specifikuje. Napríklad: Šedesátá léta $v$ architektuře Slovenska. Výzkum prostřednictvím autobiografických výpovědí.

Asi je už minulostí dávný alibisticky zvyk, vyplývající z vědecké skromnosti, kdy měly mnohé časopisecké příspěvky i knihy v názvu předložku „k“ ( $v$ němčině zu, v angličtině „on“). Tak začínal např́klad epochální Einsteinův článek Zur Elektrodynamik bewegter Körper. Marx zase napsal Zur Judenfrage (On the Jewish Question). $Z$ anglického about se u nás nejnověji stalo oblíbené nic neříkající „o“ („architektura je o umění a technice“). Možná někdy na úsvitu dějin byly latinské spisy s De na začátku, např́iklad Vitruviova slavná kniha De architectura. Neříkám však, že se pod takovými názvy nemohou skrývat hodnotné myšlenky. ${ }^{91}$

Anglo-americký vliv vnesl do názvů větší sebejistotu a jasnost, ale i víc asociativnosti, obraznosti. Název už nemusí otrocky a nudně popsat všechny komplikované souvislosti daného zkoumaného jevu, jak to s oblibou dělaly složité názvy výzkumných a jiných projektů podporovaných 
EU. Např́klad Zvýšení dostupnosti do pólů růstu v regionu Liptov a Orava, což ve skutečnosti znamená: opravíme cestu mezi vesnicemi.

V názvu často bývá pouze téma, tj. čímž se disertace zabývá, ale dobré je přidat tam i obsahové jádro, novou informaci, tedy to, co se nazývá réma. Zde je např́iklad zpřesnění podle aspektu, kterému jsem se v jednom výzkumu věnoval: Teoretické myšlení modernismu na Slovensku. Textová analýza hodnotících a teoretických článkủ časopisu Slovenský stavitel'1931-1942. Oblíbenou figurou v názvu bývá dvojtečka, která těsněji váže obě jeho části.

Podnětný je také titul ve formě otázky: Střední Evropa - také žádné architektonické téma? (F. Achleitner). Titul obsahující rematickou informaci postavenou kontroverzně vyvolává zvědavost: Ruská avantgarda-od základu nepochopený směr. (B. Groys).

\section{Abstrakt}

Abstrakt je krátký text asi v rozsahu 100 slov. (Tento odstavec má 122 slov). Bývá na začátku článku anebo knihy a měl by povzbudit čtenáře, aby pokračoval ve čtení - usnadňuje mu to poskytnutím krátké ukázky. Abstrakt díky elektronizaci nabyl trochu jiného významu, než měl původně - je samostatnější, objevuje se v různých databázích a očekává se od něj, že poskytne komprimované informace o celé práci. $V$ disertaci takto samostatně nežije, ale ožije, když práci vložíte na univerzitní elektronické úložiště. Proto by měl abstrakt dobře vystihnout podstatu celého textu a nemělo by se $v$ něm spoléhat na to, že se pak bude čist i samotná disertace. Neměl by tedy být jako ty abstrakty v programech televize, které lákají ke shlédnutí, ale rozuzlení zatají.

\section{Klíčová slova}

Obvykle nebývají požadovanou součástí disertace, jen se můžete setkat s tím, že je třeba je uvádět v souvislosti s ní. Nemusí to být pouze jednoslovná hesla, můžete použít napríklad spojení: 20. století; evropská architektura; koncertní sály a podobně. Neměly by se tam opakovat slova z názvu, používejte odborně známé termíny, které mají jasný ekvivalent $v$ angličtině. Uvádějte je $\checkmark$ pořadí podle abecedy a je vhodné jich mít asi pět až osm.

\section{Obsah}

Obsah je nejen pomůcka, jak uchopit práci na vlastním textu, ale i obraz o logické skladbě celé disertace, a nakonec návod na orientaci v ní. Vhodné je zde desetinné číslování položek v obsahu. Je však třeba dbát na míru, protože již při třímístném číslování čtenář ztrácí přehled. Podkapitoly třetí úrovně v rozsahu kolem jedné strany už do obsahu nevkládejte.

Obsah bývá většinou na začátku a zejména vědecké publikace to ctí. Jeden můj kolega vtipálek mi daroval propagandistickou brožuru v čisté slovenštině, kde veliký vůdce Kim-Ir Sen vysvětluje, co je to čučche a jeho pokyny se dotkly také obsahu knih - nemá být na konci, Korejci musí dávat obsah vždy na začátek. Má pravdu.

Paradoxní nepř́ijemnost postihla profesora Jana E. Koulu, kterému do knihy Pozerám sa na architektúru zapoměli dát obsah. Přitom to byla kniha, kterou předložil jako doktorskou práci na velký doktorát. Komise mu to omluvila.

Dejte pozor, abyste měli v obsahu uvedeny názvy součásti disertace podle jejich poslední úpravy. Názvy se totiž precizují do poslední chvíle a na opravy v obsahu se potom zapomene tak, jak ho Koula zapomněl dát úplně.

\section{Úvod}

Úvod má být krátký a koncentrovaný. Týká se to sice především populárních spisů, nicméně ani vědecký úvod by nemusel zatěžovat čtenáře, který, pokud mohu usuzovat podle sebe, úvody přeskakuje. Měl by stručně naznačit, co v textu následuje, ale určitě nemusí vyčerpat všechny informace, to přijde až v hlavních kapitolách. Úvod nemusí být otrocky propracovaný celek, může se dotknout nějaké širší souvislosti obsahu disertace, ba dokonce ji mǔže přiblížit i přes příběh samotného autora. 
Obvykle odpoví na otázky: proč toto a ne jiné téma, proč mě téma zaujalo, jaký výzkum použiji, jaký problém jdu zkoumat a jaké jsou mé výzkumné otázky či hypotézy.

\subsubsection{Hlavní části}

\section{Současný stav problematiky a přehled literatury}

Této důležité části jsme se již věnovali v páté kapitole. Zde jen připomínám, že v části s tímto dlouhým názvem se očekává, že:

1 / se popíší všechny relevantní související výzkumy a poznatky v dané oblasti a týkající se vašeho předmětu zkoumání;

2 / se dotknete i teorií, které se $\mathrm{k}$ tomu vztahují;

3 / provedete přehled hlavních děl, kterých se to týká a uvedete je zde.

Přestože se výsledky jiných výzkumů a literaturou o nich začnete zabývat na samém začátku práce, tuto část dolad'te až později, když již budete umět lépe zasadit údaje do kontextu své disertace. Tehdy už dokážete dobře napsat, že např́klad $x$ a y použili metodu $z$, ale vy ji aplikujete na jiný soubor dat a podobně.

Nepište však zbytečně obsáhlé a únavné přehledy literatury. Využijte zkušenost z psaní dobrých věcných a stručný výtahů knih a článků. Zde není místo na to pouštět se do kritiky autorů, se kterými nesouhlasíte. Spíše se snažte vybrat z nich pozitiva, uznat jejich výkony a nechat si výhrady do té části disertace, kde budete uvádět svá nová zjištění.

\section{Cíl výzkumu}

Základním rozlišením, které předurčí charakter vaší disertace, je vyjasnění toho, zda budete potvrzovat anebo vyvracet nějakou hypotézu, nebo budete hledat odpovědi na výzkumné otázky. Cíle nestavte bombasticky, ale ani triviálně. Vždy si položte kritickou otázku: skutečně takového cíle dokážu ve své disertaci dosáhnout? Ne vždy se dají použít nějaké věcné nebo finanční indikátory, ale pokuste se i o to. Nejedna grantová žádost se na to ptá. I při cílech typu „objasnit“, „pochopit“, „vysvětlit“, si pokládejte otázku, zda to vaše skromná disertace dokáže. Nemusíte př́liš ustupovat z nároků, jen nedovolte, aby mezi vytčenými cíli na začátku a zprávou o jejich splnění na konci byla propast.

\section{Metody}

Celá třetí kapitola se věnovala otázce metod. Zde bych jen doporučoval:

1 / důkladně promyslet to, co vyplývá z cílů výzkumu, protože tomu se podř́dí metody, jakými jej budete provádět. Pokud chci napríklad dokázat, že čtvercové, dvoustraně osvětlené třídy (jaké jsou ve „škole hrdinů SNP“ od J. Luuptáka a P. Csellágha) lépe ovlivňovaly prospěch žáků než třídy klasické (tj. podélné s jednostranným osvětlením), zvolím jinou metodu, než kdybych chtěl napsat o životním díle a osudech architekta J. Ĺuptáka;

2 / vyhnout se jalovým popisům obecných metod, uvažování a filozofování;

3 / uvědomit si, že zvolená metoda předurčuje profil získaných poznatků a její korektní popsání je třeba na to, aby mohly být případně ověřovány někým jiným;

4 / při výběru metody opustit úsilí o autorskou originalitu. Jde spíše o to zpřesňovat poznání tím, že přebíráte stávající metody a používáte je $v$ dalších jiných případech a souvislostech.

\section{Kapitoly}

V nejhrubším členění může, resp. musí mít prípadně disertace tyto tři „nadkapitoly“: úvod jádro - závěr. Jádro je hlavní a je v něm toho nejvíce. Obvykle se skládá z dalších kapitol. Jejich názvy pak reflektují konkrétní vnitřní obsah a je dobře, když se i zde uplatní zásady tvorby názvu tak, jako při názvu celé disertace.

Můžete se rozhodnout pro chladně věcné názvy (Naše architektura po roce 1989) nebo pro více sexy názvy, například Nové začátky - nové naděje. Ty mají nevýhodu, že je při jejich př́lišné metaforičnosti těžší se v obsahu orientovat. Hojně při sestavování tohoto textu nahližím do vtipně 
napsané knihy sociologa Dismana, ale stále nevím, co mám očekávat od podkapitoly nazvané 1.5 Máme toho moc nebo od kapitoly 2.3 Co je jádrem pudla?

\section{Diskuse}

Charles Darwin se vzpamatoval a narychlo napsal své epochální dílo, aby mu jeho objev někdo nevyfouknul. Ale neztratil nadhled nad věcí a uvedl na konci něco, co se dá nazvat diskusí: otevřeně píše o tom, $v$ čem si není jistý, a dokonce na čem by mohla jeho teorie padnout.

$\checkmark$ části disertace nazvané Diskuse (př́padně v části Závěr) má být uvedeno, jaké limity má vaše vysvětlení zkoumaného problému, $v$ jakých poměrech platí a kdy už ne, na co se hodí a co by ještě bylo třeba dále zkoumat a doplnit. Zde opust́te vyšponované sebevědomí a předvádění se, na co úžasného jste přišli, a zkuste posoudit výsledky své práce z pozice kritického oponenta. Není to na škodu, nebylo to na škodu ani Darwinovi.

Takový přístup vám může výborně pomoci při obhajobě. Tam se totiž často namítá, co všechno jste ještě měli prozkoumat. No a vy už na to budete mít v této části uvedenou odpověd'. Přiznejte se nejen k silným, ale i k slabým stránkám disertace.

Část nazývaná Diskuse tedy uvádí výsledky do širších souvislostí, analyzuje vztahy a různé aspekty dosažených poznatků. ${ }^{92}$

\subsubsection{Co je na konci}

\section{Závěr}

Když stojím po úmorné práci na větším textu před úkolem napsat závěr, ptám se sám sebe, nač? Vždyt' je to všechno podrobně uvedeno v předchozím textu, at' si jej přečtou. Omyl. Co když to někdo číst nebude a přečte si jen abstrakt nebo mu stačí jenom závěr, podrobnější než abstrakt?

Nepodceňujte závěr. Jasně, explicitně a s přiměřeným sebevědomím v něm uved'te, na co nového jste přišli jako první ve vesmíru. Nemusí to být epochální objevy. Stačí drobnost, ale její jasné stručné zformulování má místo právě zde, $v$ závěru. Připojte $k$ tomu i konstatování, že je to nový poznatek. Úkolem doktoranda není jen dokázat, že umí vědecky pracovat; má také přinést něco nového. Tak to tu pěkně pyšně uved'te. Nezůstaňte však jen na povrchu a nepište zde pouze obecné shrnutí. Navažte a rozviňte zde hlavní téma disertace.

Pokud nedefinujete svůj vlastní pohled i na nedostatky své práce, spolehněte se, že to za vás udělá oponent nebo komise. Pokud bude oponent blahosklonný, bude hledat plnění cílů $v$ jednotlivých kapitolách. Raději mu to usnadněte a dejte to soustředěně do závěru.

\section{Poznámky}

Výstavba textu a postup výkladu má svou hlavu a nedovolí vám cokoli. Řada věcí se do textu nedostane. Těžko se s nimi loučíte, protože jsou vám milé, vynaložili jste na jejich získání ohromnou energii, jsou poutavé a podobně. Když velmi vybočují z hlavní linie, vzdejte se jich, když vybočují jen málo, dejte je do poznámek. Pak budou i poznámky zajímavým čtením a nebudou jen holým seznamem bibliografických odkazů typu jméno-rok-strana. Do poznámek patří:

- bibliografický odkaz;

- odbočka, méně podstatný údaj, argument, doplňující informace a podobně;

- rozšíření myšlenky v textu, které však nezapadá do linie výkladu;

- komentáŕ, shrnutí;

- zajímavost, asociace, zvláštnost;

- doplňující technický nebo statistický apod. údaj.

No a co do poznámek nepatří? Př́liš divergentní odbočky nebo to, čím chcete jen imponovat čtenáři a čeho výpovědní hodnota je vzhledem k hlavní linii výkladu irelevantní.

\section{Bibliografie}

Jinak řečeno seznam použité literatury. To je snad jediná věc, na kterou se vztahuje státní norma. Seznam literatury je dalším důležitým vnějším znakem o obsahu, záběru a kvalitě vaší 
disertace. Vidět je na něm nejen formální důkladnost práce se zdroji, ale i schopnost postihnout klíčové prameny. Zkrátka, jestli jste normě vyhověli, nebo jste jen vypsali pár náhodných odkazů, anebo se jen přehnaně chlubíte vlastními publikacemi. Fundovaná a přiměřeně skromně sestavena bibliografie má ten účel, že souhrnně a detailně informuje čtenáře o základní literatuře na dané téma. Stručné odkazy na uvedené prameny jsou pritom ve vlastním textu anebo v poznámkách pod čarou.

Literatura může být sestavena kompaktně, může být rozdělena na knižní a časopiseckou nebo na archivní a publikované prameny a podobně. Specifika disertace se mohou se odrazit i v jinak členěném seznamu literatury, např́klad můžete uvádět samostatně díla o zkoumaném architektovi a samostatně ta, které on publikoval.

$\checkmark$ tomto seznamu mohou být ještě další rozšiřující informace o dílech citovaných v textu, údaje o překladateli, o jiných vydáních, měly by zde být nejúplnější údaje o publikaci, zatímco v textu a poznámkách pod čarou je vhodné být $v$ tom úsporný. Takže když v textu uvedete lakonicky (FOLTYN, 1993), v tomto seznamu již rozepíšete celý bibliografický údaj o citovaném díle i například to, že vyšlo již dříve v německé verzi.

\section{Rejstřik}

Rejstř́k nebývá součástí disertací, ale je na zvážení, zda by nestálo za to ho zkusit do ní dát, zejména tehdy, když nám to počítače trochu usnadňují. Pravda je, že na jeho správné sestavení by bylo třeba dočasně v elektronickém textu naše skloňovaná jména převést do prvního pádu. Asi by se to mělo udělat docela při finiši, a to je právě čas, kdy má doktorand dost práce se všeličím jiným. Já sám dělám rejstříky svých textů rád a těším se z nového pohledu na svou práci (i na to, že se už skončila). Často jsem překvapen, jaké osoby, místa a věci jsem v textu zmínil a jaká je frekvence těchto zmínek. Říkám osoby, místa, věci - nebot takové jsou většinou obvyklé registry: jmenný, místní $a$ věcný. $V$ našem případě bude věcný rejstřík sestávat pravděpodobně $z$ architektonických objektů; když je podrobnější, bývají tam i jejich přesnější adresy. Samožrejmě existují i rejstříky kombinované a spojené.

\subsubsection{Prílohy a ilustrace}

\section{Obrázky, výkresy}

Vizuální stránka disertace o architektuře je věc jasná, dávat zde rady ohledně její podoby je zbytečné. Připomínám však věcně evidenční stránku: nezapomeňte uvádět, co je na obrázku, zdroj, odkud ilustrace pochází, a jejího autora, zvláště pokud jde o fotografii nebo archiv a označení místa v tom archivu. Systém zvaný Creative Commons umožňuje autorům definovat si vlastní podmínky pro zpřístupnění autorského díla - od plného použití s uvedením autora, přes omezení na nekomerční užití nebo použití bez úprav a zachování licence. Za těchto podmínek můžete použít obrázky a fotografie z webu. Zejména první dvě podmínky, tj. uvedení autora a nekomerčnost, jsou v disertaci snadno splnitelné a vlastně samozřejmé. Autorský zákon přibližuje další stránky věci, ačkoli mi v něm nikdy nebyly jasné jemné nuance, co z veřejných staveb mám právo volně fotografovat a co už ne.

\section{Tabulky a grafy}

Tabulky bývají zrádné v tom, že se často podcení uvést v jejich hlavičce a popisu, co znamenají jako celek (název), jaké údaje a proměnné jsou v nich a odkud tabulka nebo graf pochází. Zkuste se podívat na tabulku očima úplného laika a jemu v popisu vysvětlete, o co v ní jde.

\section{Prílohy}

Disertace nemusí být zatižena př́lišným množstvím doprovodného materiálu, pokud jej můžete umístit do přiloh. Je to podobné jako s poznámkami: méně důležité odsuňte. Spíše se mi však zdá, že přesila elektronických zdrojů a nástrojů způsobuje, že se spoléháme na to, že podobné „přílohy“ máme kdesi ve virtuálním prostoru a na nějakém médiu a nemusíme je už uchovávat v př́lohové části disertace. Ale bohužel, stará média jsou překonávána novějšími a mnoho takových 
informací se právě proto ztrácí. Kdyby se zachovaly, mohly by sloužit nejen jako soubor základních faktů, ale i jako informační materiál pro výzkumy někoho jiného.

\subsection{JAK TEDY PSÁT?}

Obecné rady, jako byly ty předchozí, jsou sice principiální, ale nepř́liš pomohou tehdy, když člověk sedí před nepopsaným listem papíru - nebo moderněji: před prázdnou obrazovkou - a má začít s psaním. Zejména když ví, že mu třeba napsat alespoň sto, když ne dvě stě stran a dosud jich nikdy nedal dohromady více než deset. Kolega Karol Katoš jednou někomu radil, že má začít psát jako kdyby psal list. Já mám ve zvyku zoufale zpožděné doktorandy utěšovat starým římským divide et impera (tedy rozděl a panuj): když má mít práce deset kapitol a spolu 100 stran, rozdělte si psaní na desetiny a sesmolit těch deset stran v jedné etapě již není tak nepředstavitelné, jako když před vámi stojí ten celý obrovský stostranový úkol.

\section{Divide et impera}

Je to možné zejména v takové disertaci, kde se předmět, nebo ještě lépe objekt zkoumání, dá jasně rozdělit na části. Např́iklad když je třeba analyzovat menší skupinu architektonických objektů. Taková byla např́klad práce, která se zabývala historickými krovovými konstrukcemi v městě Trnava. Těch je takř́ikajíc uchopitelný počet. Lze je začlenit do skupin, např́iklad podle časových období, a tedy postupně popsat fakta těch pár konstrukcí a vytvořit z toho jádro práce. Samozřejmě je k tomu třeba připojit další nezbytné kapitoly, ale základ je postupně sepsán a člověka potěší, že už v tom nejhlavnějším výrazně pokročil.

Má to však jednu velkou nevýhodu - může se vytratit to, co má práce hlavně přinést, tedy syntetické završení. Někdy se při takovém postupném skládání zapomene na to, co se psalo dřive a $v$ disertaci se některé věci únavně opakují.

Přiznám se, že když jsem psal rozsáhlou monografii o architektovi Bellušovi, předběžně jsem si napsal jednu menší kapitolu. Odložil jsem si ji tak, že jsem na ni docela zapomněl. Po čase jsem ji začal psát znovu. Zdálo se mi podezřelé, že mi to jde nějak lehčeji, dokud jsem nenarazil na tu první verzi. Na řešení takovéto dilematu nestačí ani tzv. první zákon Lea Baisera (z Murphyho zákonů) o počítačích: „Pokud to ukládáte do paměti, pamatujte si kam.“

Je třeba si uvědomit, že taková rozsáhlá práce, jakou je disertace, přece jen vyžaduje jiný než obvyklý školní režim, tedy ten, kde se denně střídají předměty a témata a kde se případné úlohy formulují tak, aby se daly v průběhu týdne realizovat. Je to práce, která je podobná semestrálnímu časovému kroku, ale hlavně při ní chybí vnější regulativ a doktorand je tu odkázán sám na sebe. Ani př́padné poradenské vedení ze strany školitele nemůže zasáhnout do faktu, že vnitřní stavba dokončovaného textu, jeho nejvnitřnější parametry, jsou jen a jen v rukou disertanta. On je ten, který je v určitých ohledech zcela osamocený a musí se rozhodovat sám kůl v plotě.

O slavném spisovateli a autorovi úspěšných bestsellerů Stephenovi Kingovi byste si mohli myslet, že jeho romány se rodí dotykem múzy. Že jeho způsob psaní vám nemá co říci a že disertace je něco zcela jiného než kniha vycházející v milionovém nákladu. Natož, když víme, že bohém King propadl jistý čas i drogám. Ale v knize, kterou napsal o tom, jak psát, se dočtete, že jeho psaní vůbec není žádná rapsodická činnost inspirovaná múzou, ale dřina založená na drobné, soustavné a disciplinované práci.

\section{Márnicový klid}

King doporučuje především vytvořit si na psaní nerušený prostor. Může to být kdekoliv, musí tam však být jedna důležitá věc: „dverée, které jste za sebou ochoten zavřít." Cílem je dosáhnout márnicového klidu. Nečekejte na to, kdy vás kopne múza. Jistě, bud'te na to také připraveni a zaznamenejte si, co vám v těch náhodných okamžicích prozradila. Mnohem důležitější však je, když "múza ví, kde budete každý den od devíti do dvanácté nebo od sedmé do třetí. Pokud to ví, mohu vás ujistit, že se dř́ve nebo později začne objevovat. ${ }^{\text {‘93 }}$ 
Jistěže se to dá přizpůsobit vlastní zvyklostem, někomu stačí psát tři čtyři hodiny, někdo má raději delší zátahy.

Existuje oblíbená teorie o tom, že se homo sapiens lidstvo dělí na dva poddruhy: do prvního patři ti, kteří pracují lépe večer, do druhého zase ranní ptáčata. Pochybuji o takovém striktním dělení. Zdá se mi, že člověk je přece jen denní živočich. Odkládání hlavní činnosti na večer nebo na noc je často př́znak neschopnosti zorganizovat si svou práci. At' je to už jakkoliv, podstatnější je stanovit si vymezený čas a zejména ho systematicky dodržovat. Ani King nezmiňuje nějakou večerní práci a Lorezo Medici radil svému synovi Giovanimu: „Existuje jedno pravidlo, které bych Ti doporučoval do pozornosti predevším: vstávej brzy ráno. Toto nejenže prospěje Tvému zdraví, ale umožní Ti zařídit si a rychle provést každodenní práci. “94

\section{Kolik}

Někdy se mi podaří za den napsat jen jednu stranu, ale jindy se bližím k maximu deseti stran denně, někdy až k extrémnímu rekordu 15 stran. To jsou však strany napsané nahrubo po důkladné přípravě, ujasnění si pořadí věcí a myšlenek, které tam chci vložit, a ještě i ranní přípravě, předcházející tomu, než si ke klávesnici sednu.

Paradoxně čím připravenější to mám, tím povrchněji se chovám $k$ detailům; snažím se psát co nejrychleji proto, abych se neztratil v podrobnostech a aby mi neunikl celkový záběr. Pak je z toho text, který někdy ani sám neumím prečíst. Takto například vypadala ( $v$ „slovenštině“) první verze jednoho odstavce z páté kapitoly:

...Čím dôkalnejšie sa všakodobrníci totuo vecou zaoberajú, tým väčší je počšet rôznych formálmycy predpiwov, ktorésa $k$ veci vyjadrujú. Tu sa vyskytuje jediná normou stanivený spôsob, ako sa k bibliografickým citácácm pristupovat'. Problém je, že stále zostáva ako nemý svedok masa publikácií, ktorá sa riadial predchádzajúcou normou, more knižníc, ktorých katalógy sú zapísaneé tými predchádzajpúcimi normami. A vychádza jú časopsisy, ktorýé si ustanovili svoje, od niemomtyr trochu odpišneé spôsoby uvádznai bibliogtafických citácií.

„Všakodrbníci“ má být „však odborníci", ale co mělo být to „niemomtyr"?

\section{Tortura}

Při koncentrovaném psaní se nesmíte nechat vyrušit žádným e-mailem. Dobrý systém, který používá denně, mi popsal můj doktorand J. Žemlička: ráno odpovídá pouze na e-maily, které obdržel od šéfa, ostatní odloží na odpoledne. Hrozí totiž, že na svou reakci dostane vzápětí odpověd' a tak dále, a už je v pasti mailové komunikace, která ho odvádí stále dále a dále od hlavní práce.

Nezapomeňte samozřejmě odložit mobil.

I při psaní tohoto textu mám nutkání si sem tam něco ověřit na webu. Chyba. Základní věci musím mít už při psaní jasné a detaily, například zda je správný ten oblíbený Horatiův citát (který náhodou vím zpaměti), nebo jak to ten Churchill řekl (to si neumím zapamatovat). Nechávám to na kontrolu textu a na doplňování toho, co si při prvním psaní označím, že je nutno ověřit.

Samozřejmě, že se vynořují různá lákadla. Právě proto, že jsou zakázána, jsou velmi přitažlivá. Ó, jaké skvělé věci bych věděl vytvořit, kdybych se právě ted' nemusel otrocky prplat s tímto textem, který nejenže se mi nějak hvězdně nedaři sepsat, ale ještě $v$ něm dělám kopu překlepů, dokonce některá slova ani po sobě neumím přečist. W. Churchill o tom věděl své: „Psát knihu, to je velké dobrodružství. Na začátku je to jen taková milá a zábavná hra, vyklube se z ní milenka, později vládce a nakonec tyran."

\section{Kontrola a zpětná vazba}

Mohlo by se vám zdát, že konstatování velké osamocenosti člověka, který píše disertaci, je přehnané. Vždyt' si kteroukoliv část, ledajaký úsek textu či formulaci může s někým konzultovat. Ano, to však platí $v$ předchozím stádiu, kdy probíhá vlastní výzkum, když se řeší nadhozené problémy nebo ty, které se $v$ průběhu řešení dodatečně vynořily. Konzultovat má smysl, když se rozhoduje o skladbě 
budoucího textu jako celku, když se sestavuje a zásadně upravuje pracovní obsah. Tehdy si úvahy nenechávejte jen pro sebe a testujte si své otázky na školiteli a na kolezích.

Za studentských dob doktorand zjistil, že naše univerzitní kultura velí, aby byly všechny práce hodnoceny a známkovány nebo aby sloužily ke kvalifikačnímu postupu či získání titulu, a tak zapomíná, že zpětná vazba od vrstevníků a pokročilejších odborníků slouží „,normativním a instrumentálním cílům “ ${ }^{95}$ přičemž pod normativním se myslí uznání vědeckou komunitou a pod instrumentálním zase vylepšení práce.

Stádium vlastního psaní je však už čas drobné práce na výstavbě textu, která probíhá jen a jen vlastnoručně. Dokonce se zde nedoporučuje radit se ani o detailech. S. King k tomu ř́ká: „možná príjde okamžik, kdy budete chtít svou práci ukázat blízkému př́teli ... at už proto, že jste na svou práci hrdí, nebo proto, že máte pochybnosti o její kvalitě. Nejlepší rada, jakou vám mohu dát je: odolejte tomuto pokušeni. ${ }^{\text {‘96 }}$

Vědecký text určitě netřeba posuzovat s takovým důrazem na jeho literární kvality, jako když jde o beletrii. Ale i ve vědě, zejména při narativních textech, stojí za to dbát o jejich slovesnou kvalitu. I zde je výklad založen na tom, že také samotný text, ne jenom věc, kterou vysvětluje, má být podán nejen hodnověrně, ale také přesvědčivě, přitažlivě a srozumitelně.

\title{
Odležení
}

Užitečné, ačkoli často zanedbávané, je rozhodnutí nechat si první verzi textu odležet. Pamatujte na to již při přípravě časového plánu, nebot' je to právě v době, kdy už termíny hoří. Odležet, to znamená něco kolem jednoho dvou týdnů. Zatím se člověk vysvobodí z detailů a dokáže text posoudit $z$ nadhledu.

Pak je dobré souvisle text číst a soustřed'ovat se jen na opravování mechanických chyb typu překlepy. Já si tehdy jenom poznamenávám, jaké musím v dalším kroku udělat zásadnější opravy, přesuny, škrty nebo doplňky. I stylistické úpravy nechávám na později a jen si ujasňuji, jak text vypadá jako celek a čistím ho jen mimochodem. I při psaní kratších textů se doporučuje odležení a několikanásobné opravování, např́klad v takovéto postupnosti: ${ }^{97}$

\author{
Zvolit si téma \\ Rozmyslet si je \\ Udělat osnovu \\ Napsat koncept \\ Nechat uležet \\ Revidovat \\ Napsat výsledný text \\ Znovu přečíst a opravit \\ Vytisknout \\ Důkladně opravit \\ Odevzdat
}

I ve stadiu odležení zůstaňte při zemi a odolejte pokušení podělit se s někým o vaši práci. Text je sotva teprve polotovar a pro kohokoli třetího je velmi těžko stravitelný. Pouze jednou jsme udělali tu chybu, že jsme nabídli vydavateli monografii o architektuře Slovenska a poslali jsme jako vzor jednu kapitolu v takovém prvotním stadiu. Přišla záporná odpověd'. I když text v sobě skrývá ledajaké perly, nebývá je vidět za jeho hrubými chybami a velkými nepřesnostmi. Jistě, text jednou může být geniální, zatím to však na něm nikdo nepozná.

\section{Jasnost a stručnost}

Často k škrtnutím sáhni, když napsat chceš, co má být hodné, aby se četlo znovu. Horatius 
Z literárních textů a způsobu jejich psaní je možné poučit se ještě v jiné rovině. Možná se vám bude zdát paradoxní, že mluvím o stručnosti, když hlavní problém je často $v$ tom, napsat o věci přiměřeně košatý, a tedy rozsáhlý text. „Omlouvám se za tak dlouhý dopis, neměl jsem čas napsat kratši." - napsal kdysi Blaise Pascal. Tutéž moudrost znají i prostí regionální autoři - Timrava vzpomínala: „Menila, menila a menila (som) namáhave do zúfalosti, kým mi (poviedka) nevyšla úsečná a taká, ako som chcela... ". ${ }^{98}$ Standardní disertace mívá u nás něco mezi 100 až 150 stranami, jenomže i ty mohou být napsány zdlouhavými nic neříkajícími prázdnými větami, anebo jadrně a koncentrovaně, tedy stručně.

\section{Finišování}

80 procent času zabere posledních 20 procent práce.

Parretovo pravidlo

Netajím se tím, že ne rapsodický, ale systematický způsob práce je zde nejvhodnější. Nepopírám však, že i to závěrečné vyčerpávající finišování má svůj smysl. Problém je jen v tom, že takovou rozsáhlou práci, jakou je disertace, nelze celou zvládnout krátkým ponocováním a několikadenním extrémním pracovním vypětím. Na konci totiž zůstává ne principiální práce, ale dlouhé piplání se s těmi nejméně podstatnými maličkostmi.

Jak je to možné, že po deseti čteních zůstalo v naší knize na s. 244 chybné Otrovkovice namísto Otrokovice? Starý pán Foltyn, precizní absolvent Bauhausu, mi při představování své knihy řekl, že práce na ní byla taková důkladná, že tam už není žádná chybička. Ach, to si myslí každý autor, dokud neotevře knihu, když přijde z tiskárny. A ta prošla podstatně větším počtem korektur než prostá disertace. Samozřejmě, že jsem i ve Foltynově knize našel pár překlepů.

Jistěže tu mluvím o věcech druhořadých. Ale ty nejenže spoluvytvářejí hodnověrnost práce, ale někdy zastíní to hlavní, co má práce přinést. Když autor neopraví obyčejné překlepy, budete věřit tomu, že nedělá podobné chyby i ve svém hlavním uvažování? Nebo opačně: proč se autor, který přináší ten údajně pozoruhodný nový poznatek, nedokáže vypořádat s takovými malichernostmi, jako je napríklad pravopis?

Právě ted' čekám na termín obhajoby jedné disertace, na kterou jsem, při všem maximálním uznání autorova architektonického př́nosu, napsal negativní posudek. To proto, že je to text nepořádně, narychlo a na poslední chvíli sestavený a podobné nedodělky jsou i ve výstavbě jeho argumentů.

\section{Opravování}

Rukopis je už při posledním čtení autorovi dost odporný. Zkušení redaktoři vědí, že sám autor už nedokáže dobře při čtení přepínat do módu, ve kterém se už nesleduje obsah, ale jen opravují chybičky. Tehdy v textu zůstávají neuvěritelně houževnatě i věci, které prvnímu nezaujatému čtenáři padnou hned do oka. $V$ jedné mé knížce se takto podařilo, že na přebalu, titulce a v tiráži byly dokonce tři mírně se lišící názvy samotné knihy. Raději neprozradím, která to byla. Disertace není kniha, drobnosti každý oponent promine, ale stojí za to si tyto nástrahy uvědomit, přiměřeně se na ně připravit a překonat je. Tady si můžete najít někoho, kdo vám dluží laskavost a bude ochoten se podívat na text nezaujatým okem.

Zde jsou některé chyby, které hrozí při psaní na počítači:

- při ručním dělení slov po úpravách zůsta-nou v textu dělicí znaménka a zapomíná se na ně;

- ukončení ráádku Enterem nebo tabulátorem se při případném dalším zalamování musí odstraňovat;

- vkládání zbytečných vícenásobných mezer - ve Wordu to opravíme pomocí př́kazu Nahradit

(dvě mezery jednou) a jeho vícenásobným zopakováním;

- chybějící mezery za tečkami, nadbytečné kolem závorek;

- zaměňování nuly (0) za velké $O$, iks (x) za krát (x), stupňů psaných jako $O$ v horním indexu, mínus za spojovník anebo pomlčku;

- neumělé vytváření zarážek a odsouvání od okraje kombinací enteru a mezerníku; 
- chybné používání spojovníku - a pomlčky - (spojovník je kratší a bývá bez mezer, nebot' spojuje dvě slova, která úzce souvisejí: Rakousko-Uhersko, Ch. Norberg-Schulz);

- kopírování amerického způsobu psaní velkých písmen v nadpisu (Slovenské Národní Divadlo);

- za nadpisem se nepíše tečka;

- měkké l' není dlouhé ĺ;

- často se zapomene na uvozovky na konci dlouhého citátu, pak není jasné, kam sahá;

- na citaci v citaci lze použít např́klad "šipkové« uvozovky;

- nepoužívejte anglické uvozovky, ty jsou na začátku i na konci stejné;

- přednostně používejte oblé závorky, na nich dobře vidět, která je na začátku a která na konci.

\section{Ukládání a zálohování}

Ukládejte si napsaný text. Najděte si způsob ukládání, který vám nejlépe vyhovuje. Přísná zásada velí odkládat si věci na dvě oddělená místa. Zaved'te si vlastní systém a př́liš neexperimentujte. Systém nemusí být dokonalý, více záleží na jeho osvojení a na vytvoření stereotypu jeho používání. Nina B. si platí externí úložiště, Václav G. chodí se střapcem flešek, Pavel K. mi zase prozradil, že když finišuje, posílá si finální verze mailem sám sobě. Je to jedno, jen si to pamatujte a dodržujte to.

Murphyho zákony jsou plné informací o tom, co nekalého se stává při finišování. Já se také neumím ubránit dojmu, že všechny patálie čekají na závěr prací. Když jsem do nakladatelství nesl disk, na kterém jsem měl definitivní rukopis knihy o Bellušovi, nedal se načíst. Musel jsem ho zanést do firmy, která ho týden 24 hodin denně repasovala. Když jsem finišoval s textem o českých architektech, začaly mi záhadně mizet některé soubory. Dodnes nevím proč. Začal jsem to všechno hystericky leckde ukládat, pak jsem nevěděl, kde je čeho poslední verze a ve kterém souboru jsou ty dvě poslední důležité opravy, které byly asi tak na dvacáté a na padesáté straně?

$V$ prípadě, že přece jen beznadějně přijdete o nějaký text, zatněte zuby a rychle ho pište znovu, pokud se to jen trochu dá. Zjistíte, že se na něj ještě dost dobře pamatujete. Když to budete odkládat, velice rychle jej zapomenete a musíte se s ním trápit nanovo. 


\subsection{DOBRÉ RADY NA ZÁVĚR - POSEDMÉ}

Pročtěte si pozorně fakultní a univerzitní pokyny, ale seznamte se i s obvyklou formu, jakou mají (dobré) disertace.

Vytvořte si márnicový klid a stanovte si denní výkon.

Kritizovat druhého je snadné - využijte kritiku od školitele anebo kolegu jako zpětnou vazbu.

Odložte napsaný text, at' se odleží.

Často k škrtnutím sáhni...

Nezodpovězené otázky bud' dořešte, nebo je uved'te v diskusi jako otevřené.

Na zálohování si vytvořte stereotyp.

Zálohujte a pamatujte si, kde je čeho záloha, zejména ta poslední. 


\section{PUBLIKOVÁNÍ}

Mohlo by se zdát, že obhajoba je jediný cíl a práce spojená s disertací se ní skončila. Ale i po obhajobě se vás však mưže někdo laicky zeptat, nač vám to všechno bylo třeba. Hlavní a nejsprávnější odpověd' je samozřejmě ta, že budete mít na náhrobním kameni titul i za jménem. Ale laika určitě zajímá, nač jste přišli o to více, o co méně tomu rozumí. Berte to tak, že je to jeden z reprezentantů těch daňových poplatníků, za jejichž peníze jste mohli studovat. Dokážete jej uspokojit svou odpovědí tak, aby pochopil tu složitost, kterou jste vyprodukovali? Einstein prý řekl, že „věci skutečně nerozumíte, dokud ji neumíte vysvětlit vlastní babičce. ${ }^{\prime 99}$ Dnes v době postfaktické a hoaxové má popularizace vědy mnohem větší význam než v časech, kdy stavěli Atomium, aby názorně ukázali, jak si Niels Bohr představuje atom. Ráno jsem slyšel v rádiu, jak v Británii napadají montéry $5 G$ sítě, protože se na webu šírí zpráva, že ta sít způsobuje covid 19 (!).

\subsection{VĚDECKÁ POPULARIZACE}

Můžete se zeptat, proč tu nejdříve mluvím o popularizaci a až potom přijde na řadu vědecké publikování. Maroš Borský, se kterým jsem spolupracoval při výzkumu synagog na Slovensku, měl dokonce $v$ Heidelbergu, kde studoval, překvapivě zakázáno publikovat své poznatky průběžně předtím, než uzavře práce na disertaci. I klavírista, který hrál v našem studentském divadle, vystupoval pod pseudonymem, protože měli na konzervatoři zakázané hrát populárně, aby si nekazili návyky potřebné pro interpretování klasiky. To však byly výjimky.

Doktorand by si měl právě naopak cvičit svou potřebu oznámit světu něco nového, byt' zpočátku to bude jen ten malý kamínek poznání, o kterém mluvil Newton. Náš obor se nevyjadřuje metajazykem nesrozumitelným pro laiky, dokonce i elementární matematické vyjadřovací prostředky jsou nám velice vzdálené. Takže zde nestojí nic v cestě.

Publikování blízké populárnímu je dobrý způsob, jak se cvičit v tom, jak správně formulovat myšlenky a proč je vlastně třeba zveřejňovat. Jistěže se na takové cestě může z vědecké obce zatoulat nějaká ovečka do obce jiné, např́iklad literární, ale je to na škodu? Doktorandka na urbanismu A. Háblová píše kromě básní i knihy na pomezí urbanismu, poezie a komiksu. Její disertace měla název Interpretace obchodních center jako součást urbánní struktury a dovedla ji současně ke komiksově literární knize Města zdí. Život a smrt obchodních center. ${ }^{100} \mathrm{O}$ citlivém teoretiku architektury Petrovi Kratochvílovi už asi málokdo ví, že kdysi ve svých začátcích napsal výbornou sbírku povídek a nedávno něco mezi rodinnou kronikou a sbírkou povídek, odkud je také poznat jeho vztah architektuře. ${ }^{101}$

Literární a popularizující linie se nevylučuje s vědeckým přibližováním se k pravdě. I drobný výzkum, který vykoná doktorand jako nejskromnější vědec-začátečník, má smysl popularizovat. Nejen proto, abyste dokázali, že váš výzkum má smysl. Vy totiž můžete pomoci i v dalších oblastech.

\section{Více významů popularizace}

Disertace má mít pět výtisků a je určena vlastně jen oponentům a obhajobní komisi. Žádné širší publikování, natož popularizace. Ale už zde se předpokládá, že něco z disertace její autor publikoval. První hlavní smysl popularizace je oznámit svůj objev širšímu než tomu nepočetnému publiku, které se zúčastní obhajoby.

Ale popularizace má smysl také $v$ tom, že oznamujete kolegům z téhož nebo blízkého oboru, na co jste přišli. Disertant je ze samotného principu osamocený, usiluje o vlastní individuální titul a v dnešní úzce specializované vědě rozbité na drobnou mozaiku už ani výzkumníci na téže chodbě nevědí o sobě navzájem, nemluvě o vědcích z jiných disciplín. Na vědecké radě ČVUT jsem byl svědkem profesorské přednášky, při níž překvapenému uchazeči rektor z vedlejší, rivalské chemické univerzity připomněl, že u nich se toutéž věcí také jeden profesor zabývá. A to bylo na úrovni profesorské. Jaké bariéry pak leží v cestě vzájemné informovanosti doktorandů? 
Popularizace má však smysl i ve zvyšování znalostí běžných lidí, v jakési národní vědecké osvětě. Pod popularizací se rozumí nejen psaní o bombastických objevech typu Schliemanova vykopání údajné Homérovy Troje, ale také psaní učebnic, souhrnných populárních textů nebo prostě zainteresované a fundované vyjadřování se např́klad k výstavbě anebo $\mathrm{k}$ urbanistickým záměrům na obecní úrovni. Přispívá se tak k všeobecné takřečené národní kultivaci a k vyšší vzdělanostní úrovni vůbec.

Jak připomněl skvělý popularizátor vědy Václav Cílek, při svobodnějším vysvětlování věci běžnému čtenáři, posluchači nebo divákovi se dokonce může podařit problém lépe vědecky formulovat a tím ovlivnit další vědecké bádání. ${ }^{102}$

\section{Souvislost}

Popularizace má pochopitelně své limity. Vaše informace vždy budou vstupovat do nějakého omezujícího kontextu. Hlavně vznikne otázka, proč vůbec třeba o nich mluvit. Můj vůbec první článek vznikl poté, co jsme jako studenti zaměřili domy na náměstí ve Spišské Sobotě a byli jsme celí smutní $\mathrm{z}$ toho, v jakém jsou bídném stavu. Do článku se to promítlo jako bití na poplach, ale $v$ jaké souvislosti to měl ten časopis zveřejnit? To jsme si v našem nadšení moc neuvědomovali. Redakce potom $k$ tomu doplnila krátký vysvětlující úvod.

\section{Jádro věci nebo senzace?}

Pokud tedy nepíšete pro médium, které provádí pouze jakýsi sběr informací, uvažujte vždy o tom, proč by právě ted' měli váš příspěvek zveřejnit. Média totiž vždy musí vybrat z většího celku, tak, jak se denně vybírají do zpravodajství jen podstatné zprávy. Co si vyberou? No přece to, co je nejzajímavější a v prípadě bulváru poutavé především jako senzace. Všimněte si, kdy média zaujme architektura. Setkali jste se někdy s uvedením toho, že se podařilo postavit v nejlepším slova smyslu průměrný obytný dům? Nebo spiše potkáte informaci, že v Dubaji nebo tam někde postavili nejvyšší obytnou věž na světě? Bulvár více zajímá to, jak bydlí modelka xy než naše uklízečka. Dnes byla $\checkmark$ rádiu a jinde zpráva, že se znovu začaly práce na obnově Notre Dame po požáru. Slyšeli jste někdy v hlavních zprávách o tom, jak pokračuje obnova vypálené jídelny na Pustevnách?

Mnoho odborníků i vědců tento filtr přivedl $k$ tomu, že se distancují od médií. Neumí se smírit s deformacemi, které přinášejí, například s tím, že se na titulku dostane nějaký vedlejší, ale přitažlivý a chytlavý výrok, který pak vypadá jako hlavní informace. Sám se dodnes stydím za rozhovor, který jsem dal jakýmsi novinám a na jednom místě jsem upozornil, že mohutná stavební aktivita někdy postihuje památky př́lišnou očistou a oni tomu dali název: Budovatelský mor ničí krásu našich měst. Uvědomuji si však, že tlak na výrazné zprávy a zdůraznění výpovědi je zde pochopitelný.

\section{Zobecnění a konkrétní př́iklad}

Seriózní vědec zobecňuje, a i to ještě se spoustou podmiňujících doplňků, zatímco média potřebují koncentrované jednoznačné formulace. Redaktoři často musí složité a neurčité úvahy přerušit požadavkem „uved'te příklad“. V neděli byl v rádiu rozhovor s Evou Jiřičnou. Redaktorka se jí zeptala, které tři stavby v Praze jsou jí nejvíce proti srsti. Taktní architektka dlouho váhala, nakonec stěží uvedla dvě: Novou scénu a bývalý parlament, obě od Pragera. Posluchač trochu znalý věci si tak snadněji vytvoří obraz o tom, že distingovaná Jiřičná nemůže mít pochopení pro drzý Pragerův brutalismus a udělá si ten obraz snadněji právě díky těm dvěma zmíněným dílům.

Příklady jsou však zrádné tím, že mohou být v nějakém ohledu tendenční. Když jsme napsali knihu Slavné vily Slovenska, redaktoři se při rozhovoru vždy zeptali na nějaký př́klad. Mně bylo pokaždé líto, že musím zanedbat těch zbývajících 62 a mluvit jen o třech typických, přičemž vždy hrozila nějaká tendenčnost.

\section{Bulvár?}

Václav Cílek řekl, že i přispívání do bulvárního Blesku považuje za smysluplné, vždyt' tak může velké mase publika tlumočit informace, které by se k ní jinak vůbec nedostaly. Někdy se pravda stane, že je toho už přespř́liš. Když jsme dělali doprovod po památkách sorely, přišla redaktorka bulvárních 
novin a ptala se na bratislavský Slavín. Mimořádně ji zajímalo, zda jsou pod památníkem tajné podzemní prostory a co v nich je. Odpověděl jsem jí, že je tam polosuterén se skladem sekaček, hrábí a lopat. Nebyla moc spokojená, čekala něco strašidelného. Nakonec se ještě zeptala, ve které světové válce padli ti vojáci, co tam jsou pohřbeni. Co si pomyslet o takovém vzdělanostním horizontu? Asi jsem se měl potěšit tím, že ví, že těch světových válek bylo několik.

Musím však říci, že podobně jako Cílek se však setkávám ve velké většině s poučenými a vzdělanými zástupci médií a nejednou mě překvapí a potěší, jak hluboko dokáží proniknout k věci.

\section{Tři věty}

Všechna populární média mají svá omezení, a to nejpodstatnější je v limitovaném rozsahu informace. Dobré je tedy zeptat se, kolik textu nebo kolik minut se od vás očekává. Zapomeňte na to, že disertace má 120 stran, její poselství je třeba koncentrovat do několika vět. Televize, pokud se vám do ní podaří dostat, je $v$ tomto mimořádně přísná a všichni se shodují v tom, že tam je těžko ríci více než tř̌i kratší, uzavřené věty, nejlépe takové, které nelze rozstřihnout. Čas je vzácný na i velkých konferencích, ale na obrazovce je ještě mnohem vzácnější. Někteří doporučují připravit si své poselství a říct ho bez ohledu na to, jaká byla otázka. Ale řekněme si upřímně, televize je takové médium, kde je někdy důležitější být vidět než předat nějaké myšlenkové poselství. ${ }^{103}$

Obor architektura je na rozdíl od několika hluboko ponořených věd stále popisován slovy běžného jazyka a také vědecká literatura o něm a v něm je běžně srozumitelná. To způsobuje, že se zde někdy výstupy vědy považují za něco mezi vědou a popularizací.

\subsection{VĚDECKÉ PUBLIKOVÁNÍ}

\section{Publikuj nebo zahyň!}

Začali jsme tuto kapitolu o publikování tématem zdánlivě méně podstatným - popularizací vědy. Ta je přísně vzato svým významem zcela ve stínu regulérního vědeckého publikování. Řekněme si k němu pár slov, nečekejte ale vyčerpávající návod, jak úspěšně publikovat vědecké články.

Rozdíl je v tom, že přivětivá a laicky zajímavá popularizace je zaměřena subjektivně, ilustrovaná na jedinečných prípadech, cituje nejen pro moudrost myšlenky, ale i pro popularitu jejího autora, je komprimovaná, vyhrocená do napětí a často přehnaná a sebejistá, zatímco vědecký text je opačný: usiluje o objektivnost, zaujatost mu škodí, je opatrný v závěrech, uvádí jejich omezení, používá odborné výrazy a složité trpné formulace a odkazuje na osobnosti ne pro jejich autoritu, ale pro př́nos na základě racionality. Prostě jsou v něm právě ty charakteristiky, které jsme v první kapitole uvedli jako typické pro vědu, zatímco populární text má také něco z těch mimovědeckých vlastností. Oba typy oznámení mají však společný základ - usilují oznámit širšímu okruhu čtenářů něco důležitého.

Internet otevřel v tomto směru předtím neexistující možnosti svobodnějšího šíření informací a dovolil realizovat potřebu sdělit něco jiným osobám v mnohem větší míře, od svobodného psaní blogů, přes tweetování, po redigované vkládání informací do wikipedie. Toto otevření s sebou samozřejmě přineslo i množství negativních momentů. Vědecké publikování má však už dlouho stabilní mechanismy, napomáhající vyhnout se hlavním chybám a deformacím, které se mohou při tomto způsobu komunikace vyskytnout.

\section{Vědecké publikování}

Pro publikování vědeckého typu se vyvinuly požadavky, z nichž mnohé podstatné jsem již $v$ předchozích kapitolách zmínil. Především je založeno na textu čili myšlenkovém procesu, na výkladu, který dokáže sledovat analytickou linii přibližování se k vysvětlení. Ilustrace, graf, diagram, obrázek zkoumaného objektu, půdorys apod. jsou sekundární.

Hlavní, co je při vědeckém publikování klíčové pro udržení jeho poznávacího smyslu a přibližování se $\mathrm{k}$ „pravdě“, je proces ověřování předkládaných nových poznatků. To se týká také vašich vědeckých přispěvků, které nabídnete k publikování ve vědeckém časopise - budou podrobeny 
posouzení čili recenzovány. Nebudu zde detailně popisovat pozadí tohoto procesu, vzpomenu jen ty jeho souvislosti, které se dotknou doktoranda nabízejícího svůj príspěvek k publikování.

Podobně jako při popularizaci je i zde důležité uvědomit si souvislosti, tj. proč by daný časopis měl můj příspěvek zveřejnit. Je jeho téma dnes aktuální? Přitom aktuálnost může být rozličná. Např́iklad se o daném tématu dnes diskutuje (pražský premiér chce postavit vládní čtvrt' - napíšu článek s analýzou někdejší bratislavské soutěže na vládní čtvrt'), anebo připomíná něco časově smysluplného (Loos má v tomto roce kulaté výročí narození - připomenu nějaký nepřiliš známý fakt o něm). Smysluplným podnětem na publikování je samozřejmě fakt, že přinášíte nějaký nový poznatek, vyvracíte nějaký starý omyl a podobně.

Vědecké časopisy mají tu výhodu, že jsou často otevřeny pro publikování výsledků vlastních výzkumů, aniž by zaměření těchto článků muselo souviset s předem stanoveným tématem konkrétního čísla časopisu. $V$ prírodních vědách taková volnost dovoluje operativní a rychlé publikování výsledků, rádově v měsících. Také proto se za nejvyšší co do vědecké úrovně považuje časopisecké publikování, tj. to, které zachycuje nové poznatky s frekvencí kratší než je jeden rok. To se, pravda, v architektonické spisbě vyskytuje méně. Častěji se zde dbá na to, aby byla čísla tematická a tak se do nich nedostanou články, které vybočují.

Samožrejmě se situace liší v různých oborech a také se trochu obměňují priority podle toho, jak se vyvijí scientometrická byrokracie. Od dob, kdy se zjistilo, že se rozmohl počet nepř́liš hodnotných „grantových“ konferencí, ztratil příspěvek v konferenčním sborníku na své váze. Pro některé autory jsou sborníky „nejnižší forma vědecké literatury známá lidstvu, hluboko za původními články, přehledy, a dokonce i za knihami jediného autora. "Tak říká mikrobiolog Slack a dodává: „Psaní přispěvků do sborníků je obecně vnímáno jako nuda a články samotné vznikají z poslepovaných kousků jiných rukopisů s jedním či dvěma obrázky, aby se neřeklo. “04

$\checkmark$ některých oborech se autoři přizpůsobily tak, že uhnuli se svými př́spěvky do kategorie „kapitola v knize“ - a někdejší sborníky se změnily na takové knihy. To jsou však už zákulisní detaily, které nemusí doktoranda prahnoucího po publikování až tak zajímat. U vás jde spíše o to, dostat svůj příspěvek alespoň do některé z těch kategorií.

Pokud usilujete o publikování celé disertace, jste v situaci vlastně potencionálního autora knihy, protože disertace přinejmenším rozsahem již dosahuje ten formálně stanovený počet asi tř́ autorských archů, které má mít kniha. Disertace však má některé osobité parametry, které se obecně stabilizovaly, vždyt' její cíl není být knihou, ale jakýmsi zkušebním elaborátem pro získání hodnosti PhD. Takže i když ji obhajobná komise pochválí tak, že doporučí její publikování, čeká autora ještě kus práce ji do knižní podoby upravit. Není zde např́ílad prostor pro obšírně uvádění rozboru stavu problematiky, není ani vhodné ponechat tam ty definice, ke kterým se disertant poprvé přiblízil, ale které jsou pro vědeckou obec známé. Musí se také vypustit všechny takříkajíc interně školské informace. Hlavní je zodpovědět si otázku, co má dílo přinést širšímu okruhu čtenářů, jací to budou čtenáři a čím zajímavým je má knížka přitáhnout.

Mnohem větší prostor se však nabízí v časopisech, které pochopitelně nemohou publikovat stostránkové texty, a i tř̌icetstránkové jsou již na horní hranicí publikovatelnosti. Ani rafinovaná strategie rozdělení disertace na tři části a požadavek publikovat je postupně, která se kdysi vyskytovala, už dnes nemá žádnou naději na úspěch.

Disertaci, pokud tedy mluvím o publikování ex post, tj. po jejím uzavření, je třeba rozdělit tak, aby se z ní získaly a daly publikovat vyhraněnější nové poznatky. Kdosi to pod vlivem současné vědecko-publikační hysterie cynicky označil za salámovou metodu: rozdělit nový poznatek na co největší množství publikovatelných textů. $V$ našem oboru určitě nehrozí toto extrémní rozdělování, zde se vždy vynoří otázka, jak takový úzce vypreparovaný poznatek souvisí s architekturou jako celkem. Popravdě řečeno, myslím si, že ona salámová metoda by hloubce poznání v naší oblasti více prospěla, než škodila.

\section{Váha časopisů}

Zmíněné nesmírné rozmnožení vědeckých poznatků a potřeba mít po ruce ty skutečně nejkvalitnější vedla k hodnocení vědecké úrovně časopisů a k identifikování těch nejlepších. Celý 
tento proces začal Eugen Garfield (1925-2017), který založil Institute for Scientific Information (ISI) ve Philadelphii a na jehož pracích staví scientometrie, statisticky hodnotící vědeckou práci a publikování jejích výsledků. Pokusím se stručně objasnit alespoň některé nové pojmy, které se zde používají.

Kvalitní vědecké časopisy dávají došlé příspěvky důkladně recenzovat. Vyberou vhodného vědce, který zpravidla zdarma a anonymně napíše posudek, upozorní na chyby a rozhodne, zda se to celé vůbec má publikovat. Pozor, ne vždy je to takové taktní rozhodnutí, jaké uvedl E. Světlík v knize Jak zkrotil Pegasa: ${ }^{105}$
„Váš rukopis, vysoce vážený bratře Slunce a Měsíce, jsem pln oddanosti, nadšení a rozkoše přečetl. Př́sahám na duši svých předků, že jsem nikdy nečetl nic vznešenějšího. Moje zkušenost mi dává odvahu prohlásit, že perly, jako je ta Vaše, se vyskytnou tak jednou za tisíc let. Kdybych se odvážil tento poklad uveřejnit, můj vydavatel by mi ihned nařídil, abych jej měl stále před očima a nic slabšího už nikdy netiskl.
Tato neřešitelná situace mi přikazuje vrátit Váš vznešený výtvor zpět. Vrhám se Vám k nohám a pln úcty a strachu prosím o odpuštění.
Váš nejponiženěji otrok X. Y."

Právě naopak, bud'te připraven spíše na drsné odmítnutí. Neurazte se, moudré je poučit se a bud' práci opravit, anebo si dát pozor při dalším článku.

V českém prostředí jsou nejlepší domácí časopisy zařazeny do kategorie „recenzované“, což znamená nejen to, že recenzování je u nich samozřejmostí, ale i to, že přináleží do jakési domácí první ligy.

Často se potkáte s pojmem „impaktované“ časopisy. Název je odvozen od termínu impact faktor čili cosi jako „činitel dosahu." Je to pojem, který zavedl E. Garfield a posuzuje se jím, jaký dosah má daný časopis čili to, zda ho vědci čtou a uznávají víc než jiné, a hlavně, zda články v něm i citují ve svých vlastních článcích. No a čím více se citují články daného časopisu, tím je „impaktovanějši“"

To se zase týká těch oblastí vědy, kde je rychlá citace důležitá pro její rozvoj. Impact faktor se sleduje proto jen v časopisech některých exponovaných vědeckých oborů, nesleduje se při knihách, které jsou co do pohotovosti oproti článkům v časopisech pozadu. A nejen v pohotovosti, ale také $v$ tom, že nejsou tak úzce soustředěny na nové „salámově" odřezané informace, ale nové poznání vkládají ho do širšího celku spolu se známějším fakty.

Pro rychlý progres je tento systém univerzální světové vědy důležitý. Problematická je opodstatněnost vědy regionálního dosahu. Její publikace však delším časem neztrácejí svůj význam, dokonce právě naopak, jejich hodnota je vyšší. Stačí se, jak říká Václav Cílek, podívat do antikvariátů na ceny regionálních monografií.

Impact faktor nevypovídá sám o sobě o kvalitě daného článku. Mluví jen o samotném časopise, kde ten článek je. Může se samožrejmě výjimečně stát, že vysoce hodnocený časopis zveřejní omyl. Např́íklad v souvislosti s kauzou údajného vztahu očkování a autismu. Klíčovým podnětem na tuto trvající pověru byl vědecký článek, který dokazoval korelaci. Postupně se však ukázalo, že to byla nejen nepravdivá informace, ale že její autor záměrně použil zkreslující postupy a byl si vědom nedodržování korektního výzkumu. Časopis pak informoval o své chybě. V laické veřejnosti však důsledky této chytlavé informace přetrvávají dodnes spolu s nedůvěrou vůči očkování.

Méně známý je fakt, že při těch oborech, kde hektická aktuálnost nehraje tak významnou roli, se impakt faktor nesleduje. Sem patř́ i architektura, zařazená do sféry Arts and humanities.

Svého času se objevil i pojem „karentovaných“ časopisů. Odvodili jsme si ho z tištěného, dnes digitálního, periodika, které přináší rychlý přehled obsahů článků ve skupinách vědních oborů a jmenuje se Current Contents.

Agenda ISI později přešla do komerčních firem Thompson Reuters (1992) a Clarivate Analytics (2016) a její sledování zmíněných scietometrických aktivit se odehrává v segmentu, který nazývají Web od Science. 
Evropskou reakcí na americké bibliografické, citační a abstraktové databáze byl systém Scopus firmy Elsevier. Systém funguje od roku 2004 a pojmenovali ho podle pelikánovitého ptáka takatry tmavé (česky kladivouš africký), který má vědecké jméno Scopus umbretta a vyznačuje se výbornými navigačními schopnostmi.

Novější ukazatele, které hovoří ne o dosahu časopisu, ale přímo o citovanosti článku, jsou AIS (Article Influence Score v WoS) a SJR (Scimago Journal Rank v Scopus). Vytvářejí se na základě průměrného počtu citací daného článku za posledních pět, respektive tři roky.

No, a ještě na závěr něco, co se doktorandů bude týkat také až ke konci disertační dráhy, a to je citace jejich příspěvků. Když se dostanou do zmíněných sledovaných časopisů, může se jim stát, že je někdo ve svém příspěvku vzpomene. Jistěže je může kritizovat jako nesprávné, nicméně při scientometrickém měření se negativní citace nevyčleňují. Teoreticky tedy sice nějaký čas může být i úplný nesmysl hojně kriticky citovaný, ale postupně se takto odsuzovaný autor dostane mimo okruh citování. Je totiž kontraproduktivní, abyste ve svých článcích stále citovali pochybné autory pochybných př́spěvků - sami se tím deklasujete.

Někdy se ještě mluví o citačních klanech, jejichž autoři se navzájem citují ne z opravdového uznání kvality, ale pouze na základě účelové reciprocity. Ale je to jev okrajový.

Zmíněné databáze jsou nastaveny na vyloučení takzvaných autocitací. To znamená, že vylučují takové texty, kde se mezi autory vyskytuje stejné jméno na jedné i na druhé straně. Tj. nejen když sám cituji svůj vlastní článek, ale i když jsem na jedné anebo na druhé straně v širším autorském kolektivu.

Na měření individuální úspěšnosti z hlediska citovanosti se ještě využívá takzvaný Hirschův index. ${ }^{106}$ Zachycuje nejen případné četné citace jednoho mimořádného článku, ale i to, zda máte hojněji citovaných několik článků. Př́iklad: když mám citovaný jeden článek stokrát a kromě něj nic, mám $\mathrm{H}$-index 1 . V případě, že mám citovaný jeden článek stokrát, ale pak další v pořadí pětkrát, třetí v pořadí třikrát (nebo více), ale další už méněkrát, vyjde mi z toho H-index 3. Samozřejmě zde mluvíme o těch publikacích, které zmíněné dva klíčové systémy (WoS a Scopus) sledují.

Nemá však žádný velký smysl, aby se doktorand nořil do uvedených složitostí. To, co jsem zde zmínil, je jen vrchol celého scientometrického ledovce. Shrnu jen to základní, co se týče časopisecké problematiky:

- příspěvky někdo posuzuje (berte to jako pomoc zdarma, pravda, i recenzent se první dozví o těch nejnovějších, ještě nepublikovaných věcech);

- víme, který časopis je lepší (ale to neznamená, že nemá smysl psát př́íspěvky o architektuře i do regionálních vědeckých časopisů, které žádnou americkou scientometrii nezajímají);

- nakonec zjistíte, kdo a zejména co z vašich publikací se cituje, tedy co z vaší práce má pro ostatní větší smysl.

\title{
Nedostatky
}

Některá specifika v oblasti publikování jsou méně nakloněná oboru architektura. Například už jen to nejisté zařazování architektury do příslušné „správné“ oblasti věd. Ale je to i malý ohled na zvláštnosti publikování architekty a z tohoto vyplývající osobitý charakter časopisů, které se architektuře věnují. To jsou však problémy, které nemusí trápit doktoranda usilujícího o publikování.

Právě naopak, domnívám se, že by měl vycházet z charakteristických vlastností oblasti, které se věnuje, a právě drobnou vědeckou a publikační aktivitou svůj milovaný obor upevňovat v jeho typických rysech.

\subsection{DOBRÉ RADY NA ZÁVĚR - ZA OSMÉ}

\author{
Publikuj nebo zahyň!
}

Pokuste se o dobrou popularizaci a cvičte se v ní.

Poučte se i z odmítavých recenzních posudků.

Najděte si ten nejlepší časopis.

Nezanevřete ani na regionální vědu. 
Hledejte nějakou citaci nebo ohlas na svou práci. 


\subsection{CO A KDO VÁS ČEKÁ \\ Obhajoba}

Obhajoba disertace je závěrečným dějství doktorského studia. Český zákon o vysokých školách ${ }^{107} \mathrm{k}$ tomu ř́ká: „Studium se řádně ukončuje státní doktorskou zkouškou a veřejnou obhajobou disertační práce, kterými se prokazuje schopnost a připravenost $k$ samostatné činnosti v oblasti výzkumu nebo vývoje nebo k samostatné teoretické a tvưrčí umělecké činnosti. Disertační práce musí obsahovat původní a uveřejněné výsledky nebo výsledky prijaté k uveřejněni."

Po dopsání a odevzdání disertace následuje období velké úlevy, ale také nejistoty, co na to recenzenti. I ti se však někdy mučí těžkou otázkou, jak zakončit svůj posudek. Musí se totiž rozhodnout jednoznačně: ano nebo ne. $V$ některých zemích se připouštějí i mezistupně, u nichž je možnost úpravy nebo opravy disertace. $V$ podstatě to předpokládá i náš systém: uchazeč po neúspěšné obhajobě může po nějaké době předložit opravenou disertaci znovu. Tehdy se však již vynořuje podezření o fatální neschopnosti disertanta vědecky pracovat a chyby napravit. Nelze poprít, že zde trochu hrají roli i subjektivní okolnosti - s tím je dobře počítat a připravit se na to.

\section{Referát zvaný „podstatný obsah disertace“ \\ Řekni, co budeš ř́kat; řekni to; řekni, co jsi řekl.}

Jádrem obhajoby a vlastně vyvrcholením celé disertace je krátký referát čili přednáška, ve které musí doktorand pronést podstatný obsah své disertační práce, její výsledky, prínosy a splnění cílu. Tíha tohoto úkolu vede často $k$ tomu, že se referuje spíše o posloupnosti kapitol disertace jako o problému, který se řešil a vyřešil. O kapitolách nemusíte mluvit vůbec, soustřed'te se na téma, na problém, na jeho řešení, na poznatek, na který jste přišli, mluvte o jeho přínosu, novosti a využitelnosti. Nemusí to být grandiózní prohlášení o originalitě, objevnosti či průlomovosti. Od disertace se ve skutečnosti takové výkony těžko mohou očekávat. Ale nepodlehněte př́lišné skromnosti a uved'te, že jste našli v archivu nějaký neznámý dokument, že jste přesněji datovali stavbu, zjistili neznámého autora, že jste upřesnili nějakou metodu a zjistili něco trochu jiného, než se vědělo dosud, že jste přispěli k poznání tak, jak to dosud nikdo neudělal a podobně. Neobětujte v obavě, že jste vlastně na nic nového nepřišli, většinu času vysvětlování souvislostí svého tématu tak, že k uvedení vlastního prínosu vám pak nezbude čas.

$\checkmark$ době, kdy si chystáte svůj referát, už znáte oponentské posudky a víte o námitkách, které se $\checkmark$ nich objevily. Př́padně můžete nenápadně zavést argumentaci i tímto směrem, ale přímé odpovědi na ně si nechte na př́slušný čas. Není korektní odpovědět na to, o čem ještě nebyla řeč.

Při prípravě tohoto vystoupení můžete využít celou řadu pomůcek, které se hodí pro získávání pozornosti během jakékoliv přednášky. Na začátku jednotlivých částí referátu můžete např́íklad:

- udělat výstižné shrnutí,

- uvést zajímavá fakta všeobecně známá i kontroverzní,

- podat zajímavý príklad,

- přinést překvapující oznámení,

- porovnat,

- odkázat na autoritu,

- vzbudit zvědavost,

- príijít s otázkou nebo hádankou,

- uvést citát,

- ř́ci vtip,

- odkázat na vlastní zkušenost.

Možná se vám bude zdát cynická zásada, která ríká, že třetině přednášky má rozumět každý $v$ sále, třetině odborníci, třetině nikdo. Je to však jen moudré shrnutí toho, že máte 1 / celkově uvést 
své téma, 2/ promluvit o jeho vědeckém významu a 3/ přinést zcela nový poznatek, tedy detaily, které ovládáte do tohoto momentu jen vy sami.

Nepodlehněte častému studentskému zvyku natahovat donekonečna své vystoupení, abyste vzbudili dojem, že o věci víte nekonečně mnoho, dokud vás předsedající nepřeruší pro překročení časového limitu. Když se chýlí ke konci čas, který vám vymezili, směřujte k závěrům, ohlaste nadcházející konec a dodržte ho.

\section{Poznat oponenty}

Doktorand, který se zabýval Benediktem Riedem, uvedl ve své disertaci, že paní M. B. o tomto architektovi napsala něco pouze marginálního. Mohl předpokládat, že se dotyčná dáma, jinak stálá členka obhajobní komise, nepostaví nijak vlídně k jeho disertaci. Moudré je být uvážliví a uctiví i k autorům, kteří zastávají jiné názory. Umberto Eco popsal př́ihodu, jak se dlouho trápil nad svou disertací, až v pařížském antikvariátu narazil na knihu autora, který se tématem také zabýval. Byl to sice ubohý kompilát, ale na jednom místě $v$ něm přece jenom našel výbornou myšlenku, která ho osvítila a dovedla ke zdárnému konci. Eco radí: bud'te uznalí a korektní i vůči autorům, se kterými nesouhlasíte.

\section{Poznat komisi}

Komise jsou také jen lidé se svými osobitostmi a někdy zvláštnostmi. Tak či tak je to ta hrstka odborníků, kteří mají k problematice nejbliže. Když doktorand ví o i jejich zaměření a práci, může lépe rozumět i jejich otázkám, nemluvě o tom, že se na ně může i připravit. Samozřejmě, že jim polichotí, když dá najevo, že ví, čím se zabývají. Není to nic nevhodného, vždyt' ve vědecké obci máme vědět, co zkoumají naši nejbližší partneři.

Sáhnout k fatálnímu argumentu - že komise vlastně nerozumí mému výzkumu ani mým výsledkům, protože se věcí nezabývá - je zrádné. Ono je to totiž svým způsobem pravda: téma práce má být takové, že nikdo na světě neví o věci více než její autor. Ale současně má a musí přesvědčit ty ostatní, v tomto prípadě obhajobní komisi, že jeho výsledky jsou správné. Jednou jsem byl svědkem situace, kdy se neúspěšná uchazečka zeptala komise, která byla tak o jednu až dvě generace starší než ona, jestli se vůbec někdo z nich zabývá počítačovým navrhováním. Bylo zřejmé, že ne, ale současně bylo jasné, že slabé stránky její práce vidí i ti, pro které jsou detaily cizí. Jak řekl Lessing, člověk má právo kritizovat, že je polévka přesolená, i když neumí vařit.

\section{Kolik máte času?}

Když na konferenci ke stému výročí narození architekta Vladimíra Karfíka nesouhlasně vytleskali jednoho kolegu, protože několikanásobně překročil přidělený čas a nudně četl své složitosti, zjistil jsem, že nemá ani představu tom, kolik času vlastně vyžaduje čtení nějakého textu. Partneři Imre Makovcza nám jednou ve Spišské Sobotě na setkání tvrdili, že jejich přednášky trvají pět i šest hodin, a co hưř, pokoušeli se to realizovat.

Při obhajobě se zachází s časem mnohem přísněji a doba vymezená na přednesení doktorandova příspěvku bývá přesně určena, obvykle je to 20 , maximálně 30 minut. Škodí si doktorand, který natahuje čas zdlouhavou odpovědí, na jakou si zvykl při zkouškách během studia. Ačkoliv spolehnout se na to, že mě předsedající upozorní na protahování času, a tak budu vypadat jako ten, který má ještě tolik toho co říct, je stále častý móres. Pravda je i to, že ten, kdo skončí dříve a zejména bez přesvědčivého závěru, vypadá, že toho udělal málo.

Proto je dobré mít připravený jasný a přesvědčivý závěr, který v př́padě, že se při výkladu př́liš zamotáte do detailů, vytáhněte jako finální eso. Taktní předsedající totiž neukončí zdlouhavý projev striktně, ale požádá o uvedení závěru.

\section{Tři vystoupení}

Na obhajobě se od doktoranda očekávají tři vystoupení. Zmínil jsem už, že v tom prvním má pronést podstatný obsah své disertační práce. Ve druhém má odpovídat na námitky oponentů a ve třetím reagovat na otázky, které vzejdou ze závěrečné vědecké rozpravy. Užitečné je zajít sem tam na 
nějakou takovou obhajobu. Je zásadně veřejná, ačkoli někdy se o jejím termínu dá těžko dozvědět a vypadá jako schůze tajného spolku. Dá se tak poučit z jejího průběhu očima nezainteresovaného pozorovatele. Nemluvě o tom, že její hlavní význam je v tom, že se tam mluví o těch nejnovějších vědeckých poznatcích.

\subsection{PŘÍPRAVA \\ Generálka}

Poslední výbornou službou dobrého školitele je, že se obětuje a vyslechne si nanečisto připravenou prezentaci svého doktoranda. Nebývá to nic excelentního. Pamatuji se na př́pad, kdy tam tekly slzy. Ale doktorandka se poučila a premiéru zvládla výborně. Taková cvičná obhajoba je mimořádně užitečný počin a vřele ji doporučuji. Nezapomeňte si takto zkusit také odpovědi na oponentské připomínky. Když na to školitel už nemá čas, zavolejte si někoho z kolegů a využijte to biblické, že třísku v oku cizího je snazší vidět než břevno v oku vlastním. Přátelé vám rádi řeknou připomínky, když vidí, že o ně stojíte a mohou vám tím pomoci. Nakonec sami na sobě poznáte, v jaké jiné zvláštní pozici, připomínající herce na scéně, se před nimi ocitnete. Pokud se vám nic $z$ toho nepodaří, alespoň si sami pred sebou řekněte svưj prríspěvek. Není problém si ho nahrát, změřit si jeho délku, pustit znovu a kriticky korigovat.

\section{Délka}

Jedna psaná strana, to znamená 1800 znaků (i s mezerami), má přibližně 300 slov a vyžaduje asi tři minuty na přednesení. Věc se komplikuje promítáním obrázků, protože ty si automaticky žádají svůj výklad, který si nikdo nevzpomene předem napsat. Třivětný komentář k obrázku činí však asi čtvrt strany. $O$ trochu se dá zkrátit, když vložíte do obrázku informace, které pak už nečtete. Takže stručný výklad čtyř až pěti obrázků vyžaduje tolik času jako čtení jedné strany, tedy tři minuty. Pokud bych měl pokračovat $v$ této analýze, tak do předepsaných 20 minut je možno vtěsnat čtyři až pět stran textu a deset komentovaných obrázků. Pokud vám dají 30 minut, odhaduji to tak na pět až šest stran a 15 obrázků.

Trochu více toho tam můžete nacpat, když půjdete hned in medias res. Nejenže se nemusíte představit, vždyt vás představil předseda a vaše jméno a název práce jsou na prvním promítaném snímku, ale hlavně nepopisujte široké souvislosti vašeho výzkumu na úkor nových poznatků, kterých jste dosáhli.

\section{Prezentace alias powerpointování}

Vynález zvaný Power Point je skvělá věc. Netrvalo dlouho a osvojili jsme si ho. No i jeho neduhy. „Nešvar, který lze pozorovat nejen prí firemních prezentacích, ale který se stále více šiři i při vědeckých sympoziích a na univerzitách a jehož jádrem je to, že se jednoduché věty a nabubřelé pojmy promítaji přes Power Point a pak je přednášejicí prostě predčítá, je výrazem pohrdání posluchači a absolutní ztrátou toho, čemu se kdysi řikalo přednášková kultura, "ř́ká skepticky Konrad Liessmann. ${ }^{108}$

Nečtěte to, co je na obrázku, vždyt' jsme již všichni vycvičeni v tom, co se nově jmenuje multitasking. Nezapomínejte, že komise je gramotná, její členové umí číst. Nikdy nečtěte to, co promítáte, využijte to jako vodítko, které vám nenápadně připomene linii přednášky, ale přidávejte k tomu, co ukazujete, něco dalšího, tedy právě tu myšlenkovou konstrukci, která se nedá podat pouze obrázky a která je ve vaší práci to nejhlavnější. Někdy, když nefungují př́istroje (což je dost často), mám pokušení požádat doktoranda, aby to, na co přišel, řekl jen a jen slovně, bez Power Pointu.

Zkušení radí, že dobře sestavená prezentace má mít na jednom promítaném snímku maximálně pět odrážek a v každé z nich maximálně pět slov. Jestliže je slov více a tvoří ucelený text, není to už vodítko linií přednášky, ale dokument. Používejte spíše hesla než věty. Jeden snímek se má týkat jedné myšlenky. 


\section{Číst nebo nečist?}

Dobří politici se naučili číst z těch čtecích zařízení text tak bravurně, že máte dojem, že mluví z patra. Doktorandi jsou v tom však úplní začátečníci. Jistěže se už oproti dávným dobám dokázali odpoutat od otrockého a nudného čtení a mluví volně. Power Point jim pomáhá. Za dobrým přednesem na obhajobě by však měl stát předem napsaný ucelený text, až potom si k němu přiřazujte ilustrace a nedopustte, aby se vám obsah redukoval pouze na sled zajímavých obrázků, dokonce s nějakou efektní fintou typu pozadí, prolínání a podobně. I když sem tam nahlédnete do připraveného textu, bude vidět, že zde byla důkladná příprava. Pozor na to, že Power Point vás bude nutit ke ",komentáři, vysvětlení, popisu, omluvě, odkazu" a do pozadí bude odsouvat klasické možnosti „vývoj myšlenky, dovedení k tezi, prověření argumentü, postupné rétorické stupňování, emocionalizaci publika jazykem". ${ }^{109}$

Při obhajobě však nastane ještě jedna situace, při které je čtení a psaní důležité, a to je práce $s$ připomínkami oponentů. Ty má disertant předem dostatečně dlouho $k$ dispozici a může se na ně dobře nachystat. To však bývá často nejslabší část obhajoby. Na té, kde jsem byl minulý týden, uchazeč u sebe dokonce ani neměl oponentské posudky a musel si je vyžádat. Tak i vypadaly i jeho nejisté odpovědi. Neobhájil.

Častý neduh je, že se uchazečovy odpovědi nejasně vážou na připomínky oponentů. Oni je sice někdy formulují diplomaticky neurčitě, ale disertant by z nich měl vyjmout jádro, zformulovat si ho a na něj reagovat. Přitom by měl svou reakci mít jasně připravenou, vždyt na to měl dost času.

Někdy se objeví opačný problém: $v$ posudcích není žádná připomínka. Zkuste však rozvinout pozitivní zmínky a nadvázat na oceňující podněty z nich.

\subsection{ROZPRAVA VÍCEMÉNĚ VĚDECKÁ Otázky na místě}

To, co se nazývá všeobecná vědecká rozprava o tématu disertace, má také prověřovat znalosti disertanta, mělo by to tedy probíhat formou zkoušky s kladením otázek, na které dotazující vlastně ví odpovědi. Takový padlý žánr se už naštěstí nevyskytuje. Pokud však k němu dojde, je to špatně. Obyčejně to způsobí nízká kvalita doktorandova výkonu nebo výrazné nedostatky v jeho disertaci. Ale přistoupí k tomu někdy i vztek, který vzkypí v některém členovi komise a namísto diskuse následuje evangelizace. Ta se pak bud' rozšiří jako nákaza na většinu komise, nebo zůstane v původní individuální držbě. Na to však už samotný doktorand nemá žádný dopad, nemůže to ovlivnit a těžko zde dávat nějaké rady.

Pamatuji se na takovou nepříjemnou obhajobu z dějin umění, když se usilovná sběratelská disertace, která se věnovala architektuře škol na sklonku Uherska, zdála profesorce $M$. M. málo fundovaná. Dokazovala to na chybách, které svou zkušeností a orlím zrakem snadno odhalila. Nakonec své rozhořčení ventilovala otázkami typu, kdy bylo rakousko-uherské vyrovnání. Doktorandka tehdy už byla tak zahnaná do kouta, že na to ani neodpověděla. Skončilo to tak, že nejenže neobhájila, ale ani se nepokusila o reparát. Jediné, co je tu možné poradit, nedovolit, aby se věc dostala do stádia kladení takových školometských otázek. Když se začne komise ptát na to, co ví, je zle.

\section{Jak odpovědět}

Současný bezprostřednější způsob diskutování trochu ztižil doktorandům jejich odpovídání. Ustupuje totiž do pozadí rozvážný systém vědecké rozpravy, který spočíval v tom, že se nejprve položí několik otázek a pak na ně uchazeč odpovídá. Díky tomu má trochu času odpověd' si během kladení otázek promyslet a má právo zvolit si pořadí v jakém na ně bude odpovídat. Při takovém způsobu by však doktorand neměl zapomenout poznamenat si kladené otázky. Nepůsobí důvěryhodně, když po první odpovědi zapomene na to, o čem byla druhá otázka a vyžaduje její zopakování.

Tento možná těžkopádný způsob se dnes již nahrazuje bezprostřednější diskusí mezi tazatelem a odpovídajícím. $V$ takovém ping-pongu otázek a odpovědí se sice prověří pohotovost uchazeče 
a spíše se dojde k meritu dotazu, ale takoví tazatelé by spíše měli přehodnotit, zda by neměli klást hned svou první otázku jasněji.

Samozřejmě, že většina otázek ze strany moudré komise směřuje k slabým místům disertace a nejednou si je jejich vědom i její autor. Někdy to nemá smysl zastírat, pokud to už otevřeně nepřiznáte $v$ té části, která nese název Diskuse nebo Závěr. Není nutné houževnatě obhajovat neobhajitelné. Uznat, že má oponent pravdu, není servilnost, ale samozřejmost korektní vědecké diskuse.

Ale jsou i otázky, kde je uchazeč přesvědčen o své pravdě a o tom, že se protivník mýlí. Velkorysá komise jistě ocení jeho statečný polemický boj a stojí za to se do něj pustit. Dokonce tak můžete dosáhnout opačné, pro doktoranda velmi přínivé situace, která je protikladem zmíněné „epidemii nesouhlasu“ - je to je polemická diskuse mezi členy samotné komise. $Z$ hlediska závěrečného úspěchu doktoranda je to velmi slibná situace, vždy lepší než tázání se na to, kdy bylo rakousko-uherské vyrovnání. Nemluvě o tom, že dobrá věcná diskuse má sama o sobě smysl.

\section{Jak mít vždy pravdu (eristika)}

Aristoteles nazval eristikou agresivní vedení sporu a už v jeho dobách znali diskutéři logické klamy zvané sofizmy, napríklad používání téhož slova ve více významech, potvrzování čímkoliv, co teprve třeba dokázat, nebo vyvracet to, co nikdo netvrdí. Základní pravidlo slušné polemiky však je nediskutovat ",ad hominem“ (tedy „,k člověku“, k tomu, co soupeř řekl) nebo útočit na protivníkovu osobu (ad personam), ale mluvit k věci: „ad rem“.

Argumentum ad hominem byly výroky Karla Huga Kepky na adresu Dušana Jurkoviče, když se mělo projektovat brněnské divadlo: „Přiložme ... prísnější měřítko odborné na stavby p. Jurkoviče a shledáme stále se opakující nedostatky formalismu tj. citu pro správné poměry krásy. Vedle toho nejsou nikdy koncepcí v pravdě originelní, ale pouhopouhou snůškou, složením částí ... okopírovaných detailů... "Ad personam bylo napríklad odmítnutí Bellušova návrhu na projekt Slavína, údajně proto, že nebyl komunista.

V př́padě vaší obhajoby se už hůře dá uplatnit způsob „ad auditores“, při kterém se využijí sympatie posluchačů nebo jejich odpor k složitému vysvětlování.

Filozof Arthur Schopenhauer, znechucený univerzitním prostředím, když se mu nepodařilo odlákat posluchače z Heglových přednášek, napsal učebnici demagogie, spis o tom, jak mít v diskusi vždy pravdu s názvem Eristická dialektika. Nechme stranu ty triky, které jsou jasně orientované na nekorektní vedení sporu a útok na osobu protivníka, např́klad na vydráždění k přehnaným tvrzením (vždy je prý dobré odpůrce naštvat, pak už nedokáže věcně argumentovat) a všimněme si jenom nekterých mírnějších.

Schopenhauer například radí, jak reagovat na námitku, že vám diskutující „nerozumi“. S tím jsem se setkal při jedné diskusi o bratislavské budově Národní banky, která byla v soutěžním návrhu čtyřhranná, ale nakonec museli jeden roh zaoblit. Když jsem se zeptal, zda ztracený roh není na škodu, M. Z. řekl, že takové tématu „nerozumi“. Rezignoval jsem, neznal jsem tehdy ještě eristiku. Schopenhauer radí na otázku „nerozumím tomu, co říkáte, “ reagovat např́klad takto: „Při vašem důvtipu určitě věci porozumíte, vina je na mé straně - nejasně jsem ji vysvětlil."

Několik triků je založených na indukci, tj. na postupném uvádění výroků, s nimiž soupeř souhlasí. Pořadí je přitom dobré zastř́ít, aby soupeř nevytušil, kam míríme. Když z nich nakonec vyvodíme závěr, nezbude mu než s ním souhlasit.

Část triků v Schopenhauerově sbírce je založena na tom, že tvrzení protivníka rozvedete doširoka, daleko za hranice jeho výroku nebo dokonce až na věci, se kterými už ani nesouvisí. Své vlastní výroky zbytečně nerozvíjíte. Na soupeřových široce rozvinutých vyjádřeních se totiž jistě dají najít nedostatky. Nebo původně relativně myšlené tvrzení zobecníte a potom zvrátíte. (Aristotelův příklad: Černoch je černý. Ale chrup má bílý. Tedy černý je a zároveň není.)

Další triky jsou například odvedení pozornosti, vztažení k něčemu jinému, odkaz na víru, tradici nebo běžnou praxi, prípadně použití protivníkova argumentu na důkaz opaku. Například jsme nedávno řešili otázku, zda výzkumnému středisku finančně přispívat, když dokázalo svoji neúspěšnost 
tím, že nezískalo externí grant. Nezhodli jsme se na odpovědi, protože logické také je přispívat mu jen když grant získá a tím prokáže svou opodstatněnost.

Karel Čapek zformuloval podobně dvanáct „figur při zápase perem“110, on však měl na mysli ne ústní, ale písemnou polemiku. Ǩada jeho figur je založena na přehánění, na posunutí protivníka do takové pozice, ve které ho je snadné kritizovat. Polemizuje se např́ílad s tím, co soupeř neměl na mysli a ani netvrdil. Nebo se o něm drtivě tvrdí, že neměl pravdu nikdy a v ničem.

Eristika má bohatou historii a také dnes najdete publikace, které radí „jak správně argumentovat a vždy přitom zvítězit" ${ }^{111}$

Neuvádím zde však ty různé triky proto, abyste jste je při obhajobě použili. Ty písemné Čapkovy se koneckonců na ústní spor ani nehodí a ty Schopenhauerovy mohou vést $k$ tomu, co se stalo i jemu: $k$ neslavnému odchodu z půdy alma mater. Něco z nich se však může objevit v soupeřově argumentaci a vy můžete zkusit moudrost Aristotela, Schopenhauera či Čapka využít ve svůj prospěch.

\subsection{DOBRÉ RADY NA ZÁVĚR - ZADEVÁTÉ}

Udělejte si generálku čili simulovanou obhajobu

Dodržte předepsaný čas.

Jedna strana = tři minuty.

Nepodlehněte svodům Power Pointu.

Obracejte se ke komisi, ne k plátnu, na které promítáte.

Mluvte o problému a nových poznatcích, nikoliv o kapitolách.

Skromně, ale jasně uved'te, na co nového jste přišli.

Důkladně si připravte odpovědi na připomínky oponentů.

Poznamenávejte si otázky, které dostáváte $v$ rozpravě.

Diskutujte k věci. 


\section{ZÁVĚR}

Ted' si musím sám připomenout radu, kterou jsem dával v části 7.4 .3 o tom, že v závěru třeba vždy pořádně uvést, o čem se dřive mluvilo:

Proč jsem na začátku psal o vědě jako celku a o jejích novějších tendencích? Chtěl jsem ukázat, že i takový nejistý obor, jako je architektura, tam své místečko má. Nemluvě o tom, že jsem tak mohl připomenout Feyerabenda, podle kterého mezi vědou a uměním (a architekturou) není až tak hluboká propast, jak nám to tvrdí ortodoxní př́rodovědci. Téma, kterému se jako doktorandi budete věnovat, vzniká sice nejprve mimo vás, $v$ hlavě školitele, ale posléze $s$ ním budete sami pracovat a není na škodu, když je vám milé. Nezapomínejte na jeho zužování, umožní vám řešit problém do hloubky. Newton ř́kal, že toho hodně dosáhl, protože stál na ramenou obrů. Udělejte totéž a důkladně stavějte na tom, čeho už současné poznání dosáhlo. Cestami a cestičkami zvanými ve vědě metody jsem se zde zabýval nejen z filozofujícího nadhledu, ale i ze skromného podhledu naší vědní disciplíny. Od Newtonových dob naše poznání o kus pokročilo, o to důležitější je zjištóvat a vědět, co vědí jiní. Nezapomínejte však na to, že moudrosti jiných nesmíte krást. Uvádějte důkladně, kdo je jejich autorem a dodržujte zásady vědecké citace nejen z hlediska elementární či vědecké etiky, ale také proto, že tím umožníte jiným o novém poznání diskutovat a ověřovat si jeho správnost. Nejvíce jsem toho měl co ríct k tématu vlastního psaní disertace. Shrnul jsem tu svoje trampoty i cizí zkušenosti s koncipováním a psaním rozsáhlejších textů. Přidal jsem také pár pravopisných pokynů a praktické rady, kde a jak nerušeně psát nebo jak naložit s odkládáním na zítra, tedy s prokrastinací. Chyba by byla, kdyby psaní bylo jen věcí závěrečného finišování, a proto jsem zde připomněl nejen vznešené vědecké publikování, ale i prostší vědecko-popularizační psaní, které může být jeho předstupněm. Na konci těžké práce doktoranda stojí obhajoba disertační práce, při které číhá několik pastí. Snadno se mi o nich piše, dost jsem jich totiž viděl z druhé strany barikády jako oponent nebo člen komise. Zkusil jsem tu tedy shrnout to, co by adepti mohli zlepšit u obhajování svého disertačního díla. Je na vás, co si z těchto zkušeností vyberete, z čeho se poučíte a čemu tak či tak propadnete, jak to hrozí při kognitivních omylech, které sem tam uvádím.

Po přečtení receptářů tohoto typu mě vždy ohromuje jejich košatý obsah. Současně mě však ochromuje moje neschopnost všechna ta moudra do sebe vpravit. To, co jsem neskromně nazval dobrými radami na konci každé z kapitol, byl můj pokus zjednodušit věci a vybrat ty nejpodstatnější. Zkusím zcela na závěr vybrat z nich rady vůbec „nejmoudřejši“:

\section{$O$ vědě:}

Bud'te zdravě skeptičtí a zvědaví.

Neřešte, kam patří architektonická věda, ale přispějte $k$ její kultivaci dobým výzkumem. Hledejte si svobodně své téma v tradiční nebo aktuální oblasti či na jejich hranicích.

\section{K tématu:}

Formulujte problém, který jdete řešit, tak, aby mu rozuměla vaše babička.

Téma zužujte a zužujte.

Lepší je hlubší ponor než jalová osvěta a namísto popisu objektu řešte jeho problém.

\section{K metodè:}

Namísto obecných metod mluvte konkrétně o své metodice.

Namísto triviální hypotézy raději zformulujte hluboké výzkumné otázky.

Metodu nevymýšlejte, ale okopírujte.

\section{Co vědí jiní}

Zjistěte, co všechno už vědí jiní.

Vytvořte si své vlastní databáze nebo kartotéky.

Propracujte se ke kličovým (nejcitovanějším) autorům a sledujte jejich publikace. 
O citovaní:

Údaje při knize jsou: AUTOR - název - místo - (vydavatel) - rok - (počet stran) - standardní číslo. Údaje při článku jsou: AUTOR - název článku - název časopisu - ročník - rok - číslo - strana od-do (ISSN).

Jasnost a jednotnost citací a dobrý seznam literatury naznačují kvalitní disertaci.

K etice:

Přečtěte si a dodržujte etický kodex.

Pozor na plagiátorství, i nevědomé.

Vlastní musí převažovat nad převzatým.

$\underline{\text { K psaní: }}$

Vytvořte si márnicový klid a stanovte si denní výkon.

Odložte napsaný text, at' se odleží.

Na zálohování si vytvořte stereotyp.

O publikování:

Publikuj nebo zahyň!

Cvičte se při popularizaci.

Poučte se i z odmítavých recenzních posudků.

Před a při obhajobě:

Udělejte si generálku čili simulovanou obhajobu.

Dodržte předepsaný čas.

Mluvte o problému a mových poznatcích, nikoliv o kapitolách. 


\section{LITERATURA}

BAKOŠ, Ján, 2020. O monografii. In: Periféria a symbolický skok. Bratislava: Kalligram. s. 98-106. ISBN 8071493643. (Původně: Romboid 16, 1981, s. 62-72).

BENČO, Jozef, 2001. Metodológia vedeckého výskumu. Bratislava: Iris. 194 s. ISBN 80-89018-27-0.

BLOCH, Arthur, 1992. Murphyho zákony a ešte viac príčin, prečo sa veci kazia. Bratislava: Arimes. 101 s. ISBN 80-900564-9-0.

BOCHEŃSKI, Józef Maria, 2019. Slovník filozofických pověr. Praha: Leda. 212 s. ISBN 978-80-7335-6132.

BORDEN, lain, Katerina Ray RÜEDI, 2006. The Dissertation: An Architecture Student's Handbook. 2nd ed. Amsterdam: Architectural Press 330 s. ISBN 0-7506-6825-3.

BOŘUTOVÁ, Dana, 2009. Architekt Dušan Samuel Jurkovič. Život a dielo. Bratislava: Slovart. $382 \mathrm{s.}$ ISBN 978-80-8085-665-6.

CÍLEK, Václav, 2016. O popularizaci vědy. Edice Věda kolem nás. Praha: AV ČR. 19 s. ISSN 2464-6245.

ČAPEK, Karel, 1931. Marsyas čili na okraji literatury. Praha: Ot. Štorch-Marien. 259 s.

ČERNÍK, Václav, Jozef VICENÍK (eds.), 2004. Problém rekonštrukcie sociálnych a humanitných vied. Bratislava: Iris. 236 s. ISBN 80-89018-84-X.

ČMEJRKOVÁ, Světla, František DANEŠ, Jindra SVĚTLÁ, 1999. Jak napsat odborný text. Praha: Leda. 225 s. ISBN 80-85927-69-1.

DESCARTES, René, 1970. Pravidlá na vedenie rozumu. In: Antológia z diel filozofov. Novoveká racionalistická filozofia. Bratislava: Epocha. s. 59-76.

DESCARTES, René, 2016. Rozprava o metodě. Jak vést správně rozum a hledat pravdu ve vědách. (Prel. Karel Šprunk.) Praha: Oikoymenh. 77 s. ISBN 978-80-7298-212-7. [DESCARTES, René]: Discours de la méthode pour bien conduire sa raison, et chercher la verité dans les sciences. Leyden 1637.

DÉVÉNYI, Tibor, 1985. Kariéra dr. Gézy Tamhletoho aneb vědci a hlodavci. Praha: Mladá fronta. 177 s. DILTHEY, Wilhelm, 1980. Život a dejinné vedomie. Bratislava: Pravda. $396 \mathrm{s.}$

DISMAN, Miroslav, 2011. Jak se vyrábí sociologická znalost. Př́ručka pro uživatele. Praha: Karolinum. 372 s. ISBN 978-80-246-1966-8; ISBN 978-80-246-2619-2. Dostupné na:

https://is.muni.cz/el/1421/podzim2015/MVK_23/um/54991882/Disman_Jak_se_vyrabi_sociol ogicka_znalost.pdf (cit. 3. 11. 2020).

DORN, Ralf, Werner DURTH, Udo GLEIM, Helge SVENSHON, 2011. Ernst Neufert 1900-1986. Leben und Werk des Architekten. Darmstadt: Technische Universität.

DOYLE, Arthur Conan, 1957. Štúdia v červenom. In: Pes Baskervilský. Výber z noviel. Bratislava: SPKK. $495 \mathrm{~s}$.

DULLA, Matúš - Henrieta H. MORAVČíKOVÁ, 2002. Architektúra Slovenska v 20. storočí. Bratislava: Slovart. 512 s. ISBN 80-7145-684-5.

DULLA, Matúš, 2008. Metodológia výskumu. Pracovná príručka pre doktorandov. Bratislava: FA STU. $38 \mathrm{~s}$.

DULLA, Matúš, 2010. Architekt Emil Belluš. Bratislava: Slovart. 327 s. ISBN 978-80-556-0293-6.

DULLA, Matúš a kol., 2014 a 2015. Kapitoly z historie bydlení. Praha: Nakladatelství ČVUT. 279 s. ISBN 978-80-01-05433-8.

DULLA, Matúš, 2015. Interpretácia monografiou. Biografický žáner v nových vel'kých publikáciách o významných slovenských architektoch. Architektúra \& urbanizmus 49, 1-2, 44-63. ISSN 0044-8680. 
DULLA, Matúš, 2016. Teória a veda v architektúre a urbanizme: pät'desiat rokov časopisu A\&U. Architektúra \& urbanizmus 50, č. 3-4, s. 4-17. ISSN 0044-8680.

DULLA, Matúš a kol., 2019. Zapomenutá generace. Čeští architekti na Slovensku. Praha: Nakladatelství ČVUT. 408 s. ISBN 978-80-01-06600-3.

DURNOVÁ, Anna - Christopher WEIBLE, 2020. Vědou proti pandemii - nebo raději ne? Hospodářské noviny, 25. 4., č. 080, 24, s. 14. ISSN 0862-9587.

ECO, Umberto, 1997. Jak napsat diplomovou práci. Olomouc: Votobia. 271 s. ISBN 80-7198-173-7.

FAJKUS, Břetislav, 1997. Současná filosofie a metodologie vědy. Praha: Filosofia. 135 s. ISBN 80-7007170-2.

FAJKUS, Břetislav, 2005. Filosofie (vývoj, současnost a perspektivy) a metodologie vědy. Praha: Academia. 339 s. ISBN 80-200-1304-0.

FEYERABEND, Paul, 1991. Rozprava proti metodě. Praha: Aurora. 430 s. ISBN 80-7299-047-0.

FEYERABEND, Paul, 2004. Věda jako umění. Rychnov nad Kněžnou: Ježek. 116 s. ISBN 85996-37-5.

FEYNMAN, Richard P., 2000. Snad ti nedělají starosti cizí názory. 2. vyd. Praha: Aurora. 271 s. ISBN 8085974-9-8.

FILKORN, Vojtech, 1960. Úvod do metodológie vied. Bratislava: SAV. $414 \mathrm{~s}$.

FILKORN, Vojtech, 1998. Povaha súčasnej vedy a jej metódy. Bratislava: Veda. 377 s. ISBN 8022405647.

FRANCŮ, Dušan, 1984. Porovnanie Bratislavy s inými hlavnými mestami. Architektúra a urbanizmus 18, č. 2, s. 91-109. ISSN 0044-8680.

GAVORA, Peter a kol., 2010. Elektronická učebnica pedagogického výskumu. [online]. Bratislava: Univerzita Komenského. Dostupné na: http://www.e-metodologia.fedu.uniba.sk/ ISBN 97880-223-2951-4 (cit. 3. 9. 2020).

GAVORA, Peter, 2007. Sprievodca metodológiou kvalitatívneho výskumu. 2. vyd. Bratislava: Vydavatel'stvo UK. 229 s. ISBN 9788022323178.

GAZDA, Jan, Václav LIŠKA, Bořivoj MAREK, 2019. Kritické myšlení - dovednost (nejen) pro 21. století. Praha: Nakladatelství P3K. 88 s. ISBN 978-80-87343-88-3.

GOLDACRE, Ben, 2018. Zvrátená veda. Bratislava: Computer Press. 312 s. ISBN 978-80-264-0170-4.

GONDA, Vladimír, 2001. Ako napísat' a úspešne obhájit' diplomovú prácu. 3. vyd. Bratislava: Elita. 117 s. ISBN 80-8044-075-1.

HÁBLOVÁ, Anna Beata, 2017. Města zdí. Život a smrt obchodních center. Praha: CAMP. ISBN 978-807363-861-0.

HÁBLOVÁ, Anna Beata, 2019. Nemísta měst - Opomíjená, pomíjivá a míjená místa měst. Praha: Host. 168 s. ISBN 978-80-7577-992-2.

HAUBERG, Jørgen, 2011. Research by design - situating practice-based research as part of a tradition of knowledge production, exemplified through the works of le Corbusier. AE Architecture and Education Journal 5, No 11, pp. 57-76, ISSN 1646-6756.

HENDL, Jan, 2008. Kvalitativní výzkum: základní teorie, metody a aplikace. 2. vyd. Praha: Portál. 407 s. ISBN 978-80-7367-485-4.

HLAVÁČEK, Ivan, Jaroslav KAŠPAR, Rostislav NOVÝ, 2002. Vademecum pomocných věd historických. 3. vyd. Praha: H+H. 544 s. ISBN 80-7319-004-4.

HOFSTADTER, Douglas, 2012. Gődel, Escher, Bach. Existenciální gordická balada. Metaforická fuga o mysli a strojích v duchu Lewise Carolla. Praha: Dokořán a Argo. 830 s. ISBN 978-80-257-06404.

HOLTON, Gerald, 1999. Věda a antivěda. Praha. Academia. 214 s. ISBN 80-200-0717-2. 
HORÁČEK, Martin, 2013. Za krásnější svět. Tradicionalismus v architektuře 20. a 21. století. Brno: Barrister a Principal. 447 s. ISBN 978-80-7485-002-8.

KAHNEMAN, David, 2012. Myšlení rychlé a pomalé. Praha: Ivan Melvil. 544 s. ISBN 978-80-87270-424.

KALINA, Pavel, 2013. Umění a mystika. Od Hildegardy z Bingen k abstraktnímu expresionizmu. Praha: Academia. 346 s. ISBN 978-80-200-2294-3.

KATUŠČÁK, Dušan, 2007. Ako písat' záverečné a kvalifikačné práce. 4. vyd. Nitra: Enigma. 162 s. ISBN 978-80-89132-45-4.

KEPKA, Karl Hugo, 1909. Národní divadlo. Lidové noviny 17, č. 1, 24. 1., s. 6.

KIMLIČKA, Štefan, 2002. Ako citovat' a vytvárat' zoznamy bibliografických odkazov podl'a noriem ISO 690 pre „klasické" aj elektronické zdroje. Bratislava: Stimul. 82 s. ISBN 80-88982-57-X.

KING, Stephen 2002. O psaní. Memoáry o řemesle. Praha: Beta-Dobrovský. 222 s. ISBN 80-7306-037$\mathrm{X}$.

KITTLER, Richard, 1980. Okno ako architektonický prvok a energetický problém. Architektúra a urbanizmus 14, 3, s. 161-171.

KOVÁČ, Ladislav, 2000. Potreba syntézy prírodných a kultúrnych vied. Vesmír 78, 1999, s. 644-649, 697-700; 79, s. 46-49, 105-109. ISSN 0042-4544.

KRATOCHVÍL, Petr, 1987. Poštácká hlava. Praha: Československý spisovatel. $194 \mathrm{~s}$.

KRATOCHVÍL, Petr, 2018. Dřive než do snů... 2. vyd. Praha: Dokořán. 193 s. ISBN 978-80-7363-923-5

KROUPA, Jiří, 2010a. Školy dějin umění. Metodologie dějin umění 1. Brno: Masarykova univerzita. 253 s. ISBN 978-80-210-4247-6.

KROUPA, Jiř́, 2010b. Metody dějin umění. Metodologie dějin umění 2. Brno: Masarykova univerzita, 342 s. 978-80-210-5315-1.

KRUFT, Hanno-Walter, 1993. Dejiny teórie architektúry. Bratislava: Pallas. 703 s. plus 207 obr. ISBN 80-7095-009-9.

KUHN, Thomas, 1982. Štruktúra vedeckých revolúcií. Bratislava: Pravda. 285 s.

LE CORBUSIER-SAUGNIER, 1926. Vers une architecture, Paris 1923, něm. vyd. Kommende Baukunst, Stuttgart (Ausblick auf eine Architektur, Guttersloh 1969.)

LIESSMANN, Konrad Paul, Gerhard ZENATY, 1994. O myšlení. Úvod do filosofie. Olomouc: Votobia. 377 s. ISBN 80-85619-94-6.

LIESSMANN, Konrad Paul, 2008. Teorie nevzdělanosti. Omyly společnosti vědení. Praha: Academia. 125 s. ISBN 978-80-200-1677-5.

LIESMANN, Konrad Paul, 2015. Hodina duchů. Praha: Academia. 133 s. ISBN 978-80-200-2530-2.

LIŠKA, Václav, Zdeněk FIALA, Tomáš SEDLÁČEK, 2004. Doctorandus: průvodce budoucích Ph.D. Praha: Professional Publishing. 149 s. ISBN 80-86419-60-6.

McLYNN, Frank, 1994. Slávne listy alebo pohl'ady do zákulisia dejín. Bratislava: Slovart. 160 s. ISBN 807145-151-7.

MARX, Karl, 1956. Ke kritice Hegelovy filosofie práva. In: Spisy 1. Praha: Státní nakladatelství politické literatury, s. 225-357.

MICHL, Jan, 2012. Forma že následuje co? Modernistický pojem funkce jako carte blanche. In Funkcionalismus, design, škola, trh: Čtrnáct textů o problémech teorie a praxe moderního designu. Brno: Barrister \& Principal. s. 87-125, Dostupné na: www.janmichl.com/cz.fff.html (cit. 25. 5. 2020).

MOLNÁR, Zdeněk a kol., 2012. Pokročilé metody vědecké práce. Zeleneč: Profess Consulting. $170 \mathrm{~s}$. ISBN 978-80-7259-064-3. 
MOLNÁR, Zdeněk, 2020. Úvod do základů vědecké práce (aneb jak napsat úspěšnou disertaci). Sylabus pro potřeby semináře doktorandů. Praha, FSv ČVUT. Dostupné na: https://people.fsv.cvut.cz/ k126/predmety/d26mvp/mvp_sylabus-mvp.pdf (cit. 25. 6. 2020).

NEFF, Vladimír, 2007. Filosofický slovník pro samouky neboli Antigorgias. Praha: Mladá fronta. $453 \mathrm{~s}$. ISBN 978-80-204-1547-9.

NEUFERT, Ernst, 2009. Bauentwurfslehre. Handbuch für den Baufachmann, Bauherren, Lehrenden und Lernenden. Auflage: Bauwelt-Verlag, Berlin 1936. 39. überarbeitete Auflage: Vieweg + Teubner, Wiesbaden. ISBN 978-3-8348-0732-8.

NIĖZABITOWSKA, Elżbieta Danuta, 2018. Research Methods and Techniques in Architecture. New York-London: Routlege (Taylor \& Francis). 329 s. ISBN 978-1-138-05597-1.

OCHOA, Georg, Melinda COREY, 2000: Dějiny v datech. Věda. Praha: Knižní klub Eminent, 362 s. ISBN 80-85876-37-X.

OCHRANA, František, 2009. Metodologie vědy. Úvod do problému. Praha: Karolinum. 156 s. ISBN 97880-246-1609-4.

OCHRANA, František, 2019. Metodologie, metody a metodika vědeckého výskumu. Praha: Karolinum. 145 s. ISBN 978-80-246-4200-0.

PELČÁK, Petr, 2008. Několik poznámek k současné architektuře. Brno: Obecní dům. 120 s. ISBN 97880-254-4155-8.

PETRUS, Pavol, 1997. Božena Slančíková-Timrava: trpké ovocie z novohradskej planiny. Život a dielo $v$ dokumentoch. Martin. Osveta. 223 s. ISBN 80-88824-64-8.

PHILLIPS, Estelle M., Derek S. PUGH, 2015. How to get a PhD. A handbook for studets and their supervisors. London-Maidenhead: McGraw-Hill House, Open University Press, 280 s. ISBN-10: 0335264123; ISBN-13: 978-0335264124.

PLEŠTIL, Ondřej, 2015. Harmonikum. Temperovaný proporční systém. (Disertační práce.) Praha: FA ČVUT.

POPPER, Karl Raimund, 1997. Logika vědeckého zkoumání. Praha: Oikoymenh. 617 s. ISBN 8086005453.

PRIGGE, Walter (Hrsg.), 1999. Ernst Neufert. Normierte Baukultur im 20. Jahrhundert. Edition Bauhaus Dessau. Frankfurt am Main: Campus Verlag. ISBN 3-593-36256-2.

RYGELOVÁ, Pavla, 2010. Otevřený přistup. Jak zviditelnit výsledky své vědecké práce. Ostrava, Ústřední knihovna VŠB-TU. Dostupné na: http://dspace.vsb.cz/handle/10084/78280 (cit. 25. 6. 2020).

SILVERMAN, David, 2005. Ako robit' kvalitatívny výskum. Bratislava: Ikar. 327 s. ISBN 80-551-0904-4.

SINGH, Simon, 2000. Velká Fermatova věta. Praha: Academia. 198 s. ISBN 80-200-0394-0.

SLACK, Jonathan M. W., 2001. O vejcích a vědcích. Praha-Litomyšl: Ladislav Horáček-Paseka. 245 s. ISBN 80-7185-424-7.

SMETÁNKA, Zdeněk, 1981. Václav Mencl: Lidová architektura v Československu. (Recenze.) Památky archeologické 72, č. 2, s. 511-513.

SPITZER, Manfred, 2014. Digitální demence. Praha: Host. 343 s. ISBN 978-80-7294-872-7.

STEMPEL, Ján - Jan Jakub TESAŘ, 2012. 99 domů. Praha: Kant. 428 s. ISBN 978-80-7437-078-6.

STÖRING, Hans Joachim, 1992. Malé dějiny filozofie. Praha: Zvon. 510 s. ISBN 80-7113-058-3.

SVĚTLík, Eduard, 2002. Jak zkrotit Pegasa aneb O literární tvorbě s humorem. Praha: Academia. $191 \mathrm{~s}$. ISBN 80-200-1042-4.

SZCZYGIEt, Marius, 2012. Láska nebeská. Praha: Dokořán a Máj. 170 s. ISBN 978-80-7363-486-5 a 978-80-86643-67-0. 
ŠALING, Samo, Cyprián LACO (eds.), 1966 a 1969. Stavebnícky náučný slovník. 5. zväzok: Architektúra a typológia, Bratislava: Slovenské vydavatel'stvo technickej literatúry, 1. čast' čast' A-O a 2. čast' čast' P-Ž.

ŠESTÁK, Zdeněk, 2000. Jak psát a přednášet o vědě. Praha. Academia. 204 s. ISBN 80-200-0755-5.

ŠESTÁKOVÁ, Irena, Jan TOMANDL, 2014. Architektonické řešení prostředí pro osoby s Parkinskonovou nemocí. Praha: Vydavatelství ČVUT. ISBN 978-80-01-05644-8.

ŠKVORECKÝ, Josef, 1998. Nápady čtenáře detektivek a jiné eseje. Spisy Josefa Škvoreckého. Sv. 9. Praha: Ivo Železný. 277 s. ISBN 80-237-3548-9.

ŠVÁCHA, Rostislav, 2001. The architects have overslept: Space as a construct of the art historians, 1888-1914. Umění 49, s. 487-500. ISSN 0049-5123.

ŠVÁCHA, Rostislav, 2002. Architekti zaspali. Prostor jako konstrukt historiků umění, 1888-1914. Stavba 9, s. 30-38. ISSN 1210-9568.

TICHÁ, Ludmila, Zdeňka CIVÍNOVÁ, Michaela MORYSKOVÁ, Ilona TRTíKOVÁ, Lenka NĚMEČKOVÁ, 2016. Jak psát vysokoškolské závěřečné práce. Praha: Ústřední knihovna ČVUT. 47 s. Dostupné na: https://security.fd.cvut.cz/wp-content/uploads/2016/02/jakpsatdp_1.pdf (cit. 21. 5. 2020).

TVERSKY, Amos, David KAHNEMAN, 1974. Judgment under uncertianty: Heuristics and biases. Science, 185, s. 1124-1131.

URLICH, Petr a kol., 2006. Šedesátá léta v architektuře očima pamětníků. Praha: Česká technika Nakladatelství ČVUT. 303 s. ISBN 80-01-03413-5.

VICENÍK, Jozef, 1988. Spory o charakter metodológie vied. Problémy a tendencie. Bratislava: Pravda, $451 \mathrm{~s}$.

VOLOVÁR, Maroš, 2020. Drevený skelet v stavebej tradícii horného Potisia. (Štúdia k dizertačnej práci.) Praha: FA ČVUT.

VYBÍRAL, Jindřich, 2013. Biografická metoda po smrti autora. In: PETRASOVÁ, Tatána, Marie PLATOVSKÁ. Tvary formy ideje. Studie $k$ dějinám a teorii architektury. Praha: Artefactum Ústav dějin umění AV ČR. s. 234-251. ISBN 978-80-86890-47-0. 
Matúš Dulla

Jak napsat disertaci v oboru architektura

(c) prof. Ing. arch. Matúš Dulla, DrSc.

Odborná recenze: Petr Kratochvíl, Henrieta Moravčíková,

Tereza Zoulová

Jazyková redakce: Tereza Zoulová

Vydalo České vysoké učení technické v Praze

Zpracovala Fakulta architektury ČVUT

2020

Podpořeno vnitřní soutěží FA ČVUT, IP RPMT 2020.

Připomínky k textu poskytli doktorandi/ky Fakulty architektúry a dizajnu STU Bratislava: Kristína Boháčová, Ondrej Dóci, František Dorko, Jakub Hanták, Tomáš Hubinský, Martina Jelínková, Miroslava Kamenská, Katarína Lauková Zajíčková, Kornélia Lincéniová, Mária Novotná, Veronika Vaňová, Romana Hajduková, Kateřina Tesařová a Soňa Otiepková.

První elektronické vydání

ISBN 978-80-01-06790-1

DOI 10.14311/BK.9788001067901

Tato publikace podléhá licenci Creative Commons

\section{cc) (i) $\Theta$}


1 Zde je jeden příklad (šesté vydání), poprvé publikován v roce 1987: PHILLIPS - PUGH 2015, anebo na ČVUT: TICHÁ et all 2016, respektive prímo pro oblast architektury BORDEN - RÜEDI, 2006.

2 SINGH 2000

3 DURNOVÁ - WEIBLE 2020

${ }^{4}$ FEYNMAN 2000, 266

5 OCHOA - COREY 2000, 224.

${ }^{6}$ BOCHEŃSKI 2019, 197-198

7 OCHOA - COREY 2000

8 DISMAN 2011, 13

9 STÖRING 1991, 195.

${ }^{10}$ DESCARTES podle OCHRANA 2009, 156

11 DESCARTES 2016, 15

12 DILTHEY 1967

${ }^{13}$ Název hermeneutika zavedl F. Schleiermacher a odvodil jej od řeckého boha Herma, který přinášel lidem zprávy od bohů, musel je však překládat do lidského jazyka.

14 Windelband 1967, 529 podle OCHRANA 2009, 108

15 POPPER 1997

16 KUHN 1982

17 FEYERABEND 1991

18 FEYERABEND 2004

19 „....pro umistěni vstupních dveři platí jistá pravidla: především by neměly být umistěny proti lampě nebo stromu, což by negativním způsobem ovlivňovalo tok Čchi (...) Ložnice $v$ duchu feng shui by měla v první řadě podporovat harmonický tok výživné a smys/né energie." - tvrdí se na http://feng.shui.cz/. Anebo jinde se zase dozvíte, že „jestli při renovaci domu duchové reaguji agresívně, budete si asi muset pozvat někoho, aby je pomohl nějako uklidnit..." https://paranormal.sk/zozivota/

20 GOLDACRE 2018

21 HOLTON 1999, 189-191

22 FAJKUS 2005

23 MENCL 1980

24 SMETÁNKA 1981

25 Přesněji je to Soustava oborů výzkumu a vývoje Ministerstva školství SR č. 1055 z roku 2003

${ }^{26}$ Tzv. Metodika 17+

${ }^{27}$ ISCED Fields of Education and Training <https://www.minedu.sk/data/files/3772.pdf> (cit. 14. 5. 2020)

${ }^{28}$ HLAVÁČEK et all. 2002

${ }^{29}$ KRUFT 1993, 144.

${ }^{30}$ Neufert spojil funkcionalistické dědictví Bauhausu (působil také u Gropia) s pozdějším nacistickým totalitním úsilím (pracoval pro Speera, zabýval se normalizací). První vydání jeho knihy z roku 1936 bylo velice úspěšné a vrátil se z USA, kde zamýšlel pracovat u Wrighta. Na jeho díle se odráží spojení modernity (funkcionalistické racionality a typizačního úsilí) s totalitně direktivním státním zájmem. (NEUFERT 1936)

31 KRUFT 1993, 497

32 Dlouholetý člen redakční rady tohoto australského časopisu Richard Kittler vedl v 90. letech 20. století tímto směrem také časopis Architektúra a urbanizmus. (DULLA 2016)

33 NIĖZABITOWSKA, 2018, 12

34 ŠVÁCHA 2001, 487-500; ŠVÁCHA 2002, 30-38.

35 https://cultureactioneurope.org/news/vienna-declaration-on-artistic-research/ (cit. 7. 7. 2020)

${ }^{36}$ SILVERMAN 2005

37 FEYNMAN 2000, 262

38 URLICH 2006

39 DULLA 2019, podrobněji: DULLA 2015 
40 HORÁČEK 2013

${ }^{41}$ BORDEN - RUEDI, 2006 uvádějí tyto hlavní skupiny obvyklých témat architektonických disertací: historicko-kritické, empirické, ikonografické a ikonologické, Hegelovskou historii a teorii, sociální a politickou historii a teorii, sociální vědy, vizuální studie a osobnostní psaní (s. 18 a n.)

42 ČERNÍK - VICENÍK 2004

43 KROUPA 2010b, 215

44 MOLNÁR 2012, 39

${ }^{45}$ MOLNÁR 2012, 40

${ }^{46}$ FAJKUS 2005, 319

47 VOLOVÁR 2020, 5

48 DISMAN, 2011, 76.

49 FRANCŮ 1984

50 MOLNÁR (2020)

51 OCHRANA 2019, 41.

52 OCHRANA 2019, 44.

53 ŠESTÁKOVÁ - TOMADL 2014

54 SILVERMAN 2005, 4

55 HAUBERG 2011

56 SPITZER, 2014

57 Tato část je sestavena podle: GAZDA - LIŠKA - MAREK 2019, kde se čerpá hlavně z prací: KAHNEMAN 2011 a TVERSKY KAHNEMAN (1974)

58 Pravděpodobnost se dá zjistit pomocí vzorce $p=1-n ! /\left(n^{k}(n-k) !\right)$, kde $n$ je 365 (počet dní v roce) a $k$ je počet zkoumaných osob. Už pro $k=23$ je pravděpodobnost $50,73 \%$.

${ }^{59}$ NTK Praha dokonce v systému citace PRO vygeneruje bibliografický záznam deseti různými způsoby (APA, CSE, CSE NY, ČSN ISO 690, Harvard, Chicago (16th ed.), IEEE, ISO 690, MLA (7th ed.), Turabian (7th ed.)!

${ }^{60}$ Např́iklad časopis Umění Art má promyšlený způsob citování a uvádění bibliografických citaci i zvláštnost: nedělá inverzi jména a př́ijmení a neuvádí ISBN, které je podle ISO normy povinné.

${ }^{61}$ ECO s. 196 a n.

62 Tady jsem jenom nepatrně zkrátil citaci, kterou použil P. Kalina v naší knize DULLA 2014 na s. 111. Je to shluk jmen, kterému by pomohlo, kdyby byla př́ijemní psaná verzálami a jména autorů oddělovaná pomlčkami namísto čárek.

${ }^{63}$ Např́iklad: Citace PRO Free (https://www.citacepro.com/info); Zotero (https://www.zotero.org); Mendeley (https://www.mendeley.com/?interaction_required=true); EndNote (https://endnote.com/)

${ }^{64}$ Listy Slovákov a Čechov (ktorí chcú o sebe vediet'). ISSN 1213-0249.

65 V knize DULLA - MORAVČíkOVÁ 2002 jsme použili tento způsob.

${ }^{66}$ Já jsem v tomto textu tyto pod čárové odkazy umístil na konec textu. Nechtěl jsem výklad zatěžovat množstvím odkazů, které jsou sice korektními citacemi, nicméně nemusí být v takovémto receptáři nutně na každé stránce.

${ }^{67}$ KIMLIČKA, Štefan: Ako citovat' a vytvárat' zoznamy bibliografických odkazov podl'a noriem

pre „klasické“ aj elektronické zdroje. Bratislava, Stimul, 2002, 82 s. ISBN 80-88982-57-X.

${ }^{68}$ BLOCH 1977

${ }^{69}$ SLACK, Jonathan M. W.: O vejcích a vědcích. Praha-Litomyšl, Ladislav Horáček - Paseka 2001, 245 s., ISBN 80-7185-424-7; CÍLEK, Václav: O popularizaci vědy. Edice Věda kolem nás. Praha AV ČR 2016, 19 s., ISSN 2464-6245; SZCZYGIEt, Marius: Láska nebeská. Praha, Dokořán a Máj 2012, 170 s., tu s. 131, ISBN 978-80-7363-486-5 a.978-80-86643-67-0; KING, Stephen: O psaní. Memoáry o řemesle. Praha, Beta-Dobrovský 2002, tu s. 22, ISBN 80-7306-037-X.

70 KALINA 2013, 285

71 ECO 1997, 207

72 BOŘUTOVÁ 2009, 316.

73 MARX 1956, 316

74 Uvádí to KRUFT 1993, 445

75 Etický kodex ČVUT v Praze:

https://www.cvut.cz/sites/default/files/content/8b6ab1e1-c0aa-4b1c-a90a-f06eab2d7b7f/cs/20180307-eticky-kodex-cvutv-praze.pdf;

anebo Etický kódex zamestnanca Slovenskej technickej univerzity v Bratislave:

https://www.mtf.stuba.sk/buxus/docs/doc/Dokumenty/ETICKY_KODEX_2016.pdf 


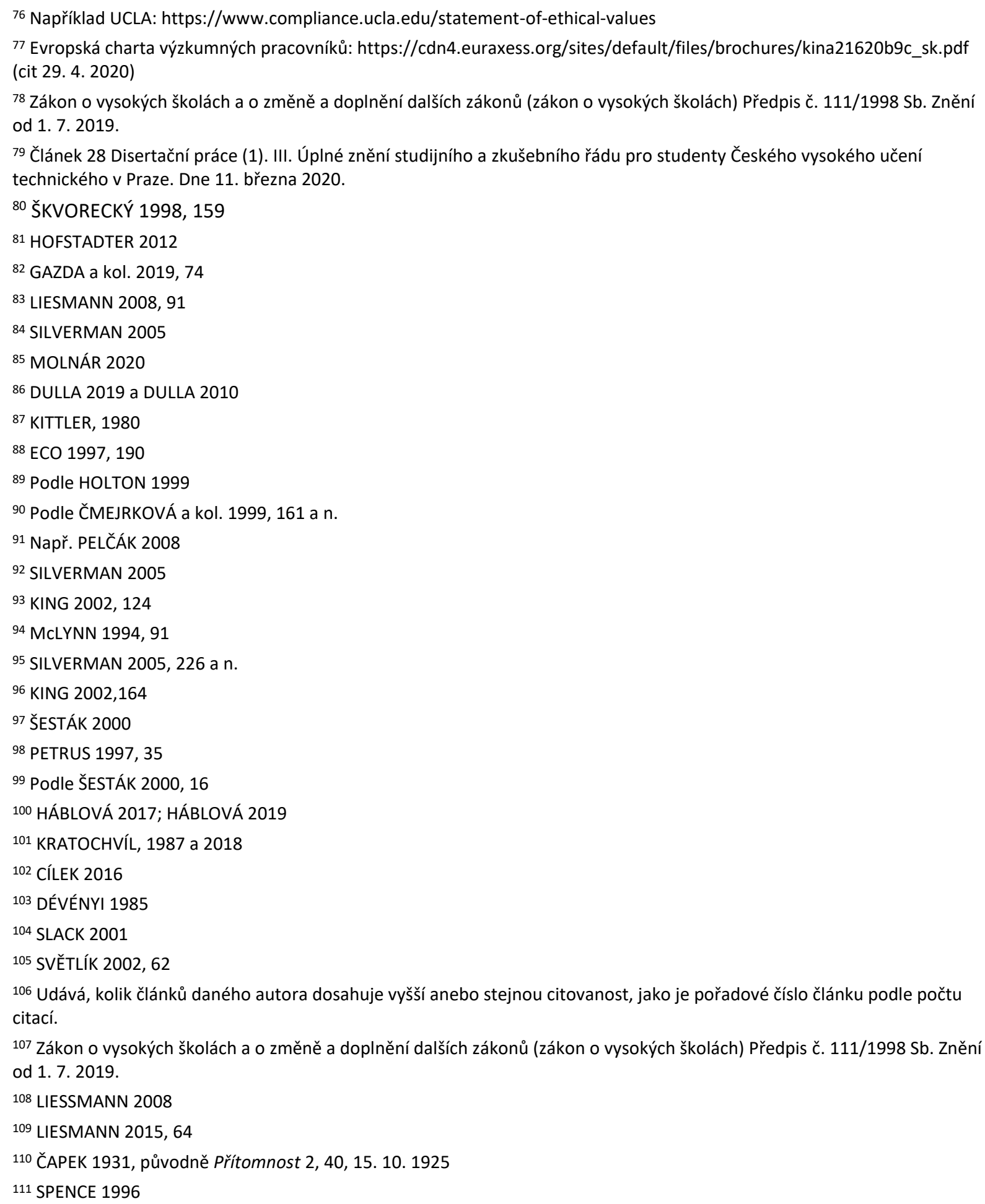

